\title{
Evaluation of Quality Assurance/Quality Control Data Collected by the U.S. Geological Survey for Water-Quality Activities at the Idaho National Engineering Laboratory, Idaho, 1994 through 1995
}

by LINDA M. WILLIAMS

U.S. GEOLOGICAL SURVEY

Water-Resources Investigations Report 97-4058

Prepared in cooperation with the U.S. DEPARTMENT OF ENERGY

Idaho Falls, Idaho

March 1997 


\title{
U.S. DEPARTMENT OF THE INTERIOR \\ BRUCE BABBITT, Secretary
}

\author{
U.S. GEOLOGICAL SURVEY \\ GORDON P. EATON, Director
}

Any use of trade, product, or firm names is for descriptive purposes

only and does not imply endorsement by the U.S. Government

For additional information write to

U.S. Geological Survey

INEL, MS 4148

P.O. Box 2230

Idaho Falls, ID 83403-2230
Copies of this report can be purchased from:

U.S. Geological Survey

Branch of Information Services

Box 25286

Denver, CO 80225-0286 


\section{CONTENTS}

Abstract

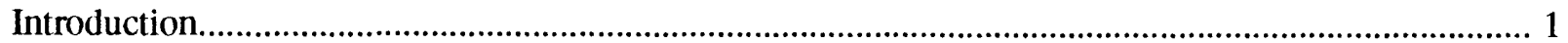

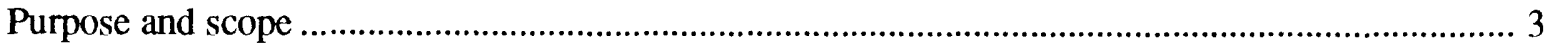

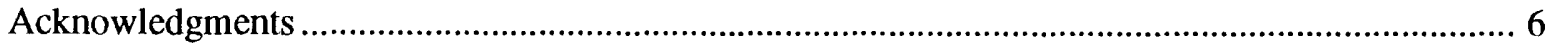

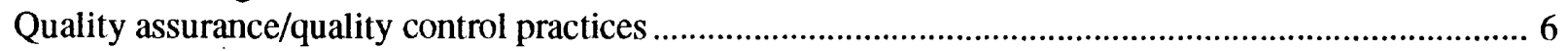

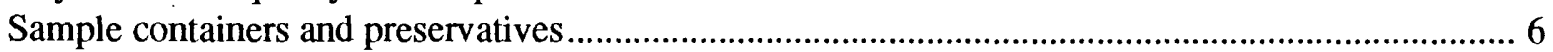

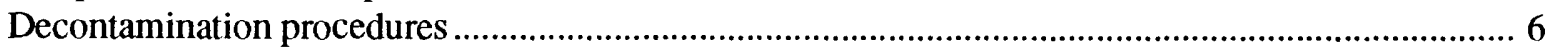

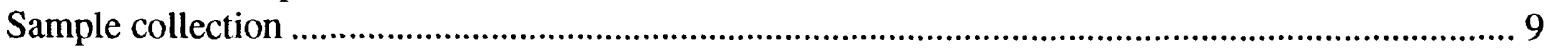

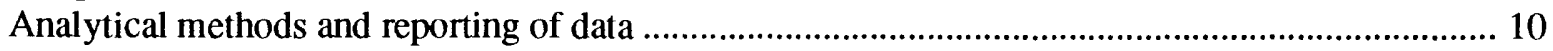

Quality assurance/quality control data, replicate pairs of samples.................................................. 12

Statistical comparisons of replicate pairs of samples ............................................................ 12

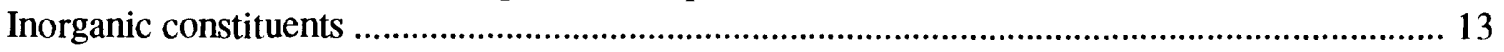

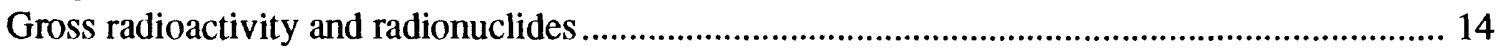

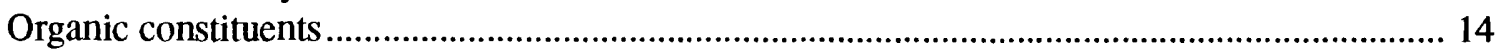

Summary of statistical comparisons of replicate pairs of samples................................................ 14

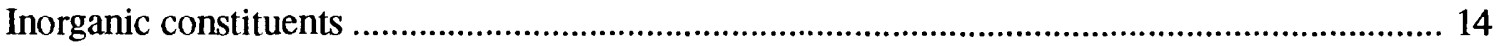

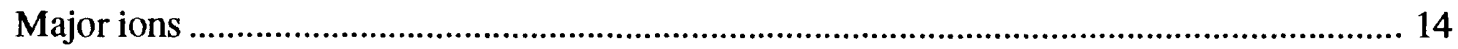

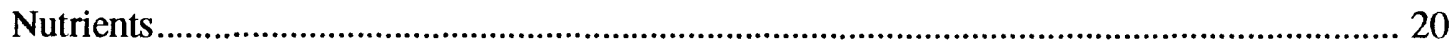

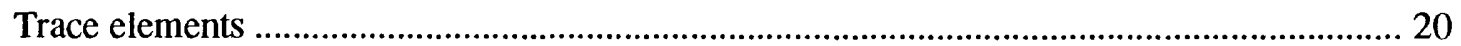

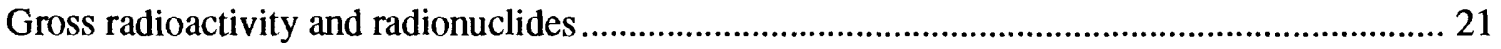

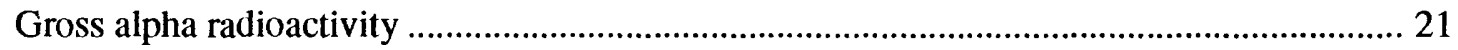

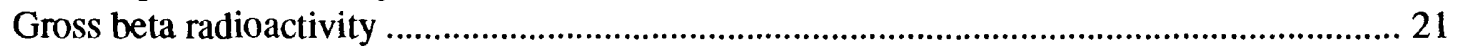

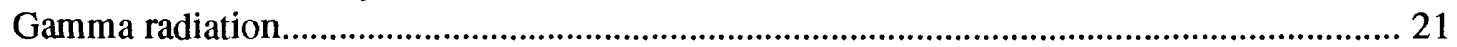

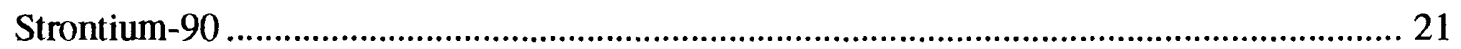

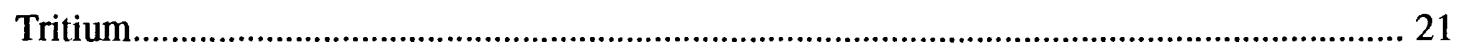

Transuranics: americium-241, plutonium-228, and plutonium-239/240 ............................ 21

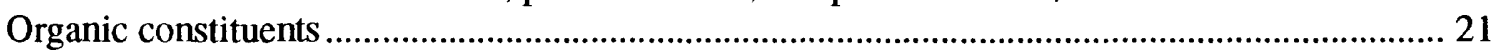

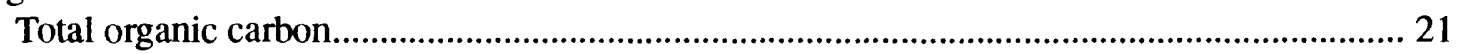

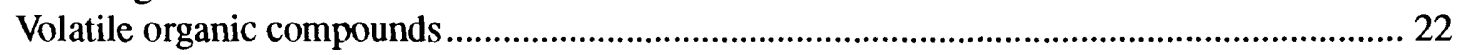

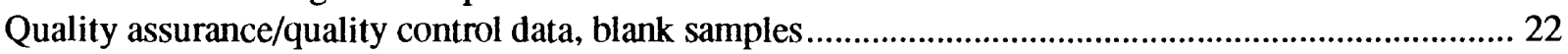

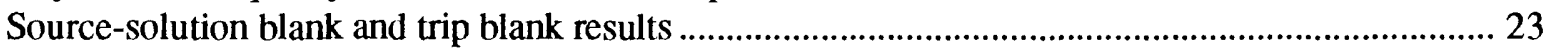

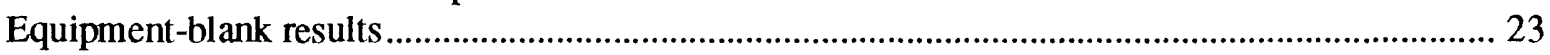

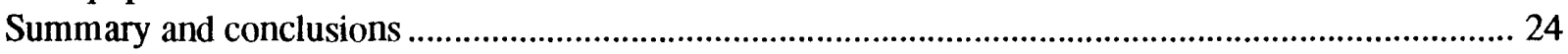

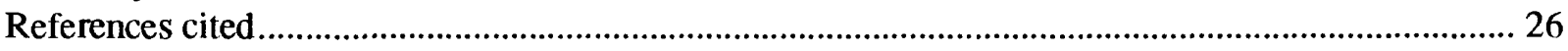

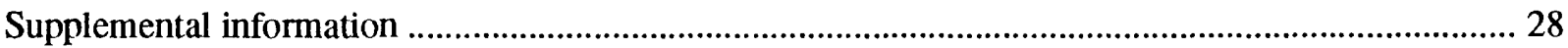

\section{ILLUSTRATIONS}

\section{Figures 1-3. Maps showing:}

1. Location of the Idaho National Engineering Laboratory and facilities where groundwater samples were collected for the quality assurance/quality control program, Idaho National Engineering Laboratory, 1994 through 1995

2. Locations of wells where ground-water samples were collected for the quality assurance/quality control program, Idaho National Engineering Laboratory, 1994 through 1995 
3. Locations of wells at the Test Reactor Area, Idaho Chemical Processing Plant, Radioactive Waste Management Complex, and Naval Reactors Facility where ground-water samples were collected for the quality assurance/quality control program, Idaho National Engineering Laboratory, 1994 through 1995

\section{Figures 4-8. Graphs showing:}

4. Results of statistical comparisons of replicate pairs of samples analyzed for major ions ........... 15

5. Results of statistical comparisons of replicate pairs of samples analyzed for nutrients .............. 16

6. Results of statistical comparisons of replicate pairs of samples analyzed for trace elements

7. Results of statistical comparisons of replicate pairs of samples analyzed for gross radioactivity and radionuclides

8. Results of statistical comparisons of replicate pairs of samples analyzed for organic constituents

\section{TABLES}

1. Laboratories and respective analyses performed for the water-quality monitoring program at the Idaho National Engineering Laboratory

2. Sample containers and preservation methods for analyses of inorganic constituents in water samples from the Idaho National Engineering Laboratory

3. Sample containers and preservation methods for analyses of gross radioactivity and radionuclides in water samples from the Idaho National Engineering Laboratory.....

4. Sample containers and preservation methods for analyses of organic constituents in water samples from the Idaho National Engineering Laboratory

5. Analytical methods used to determine inorganic constituents in water samples from the Idaho National Engineering Laboratory, and minimum reporting levels

6. Analytical methods used to determine gross radioactivity and radionuclides in water samples from the Idaho National Engineering Laboratory, and detection limits or minimum reporting levels

7. Analytical methods used to determine organic constituents in water samples from the Idaho National Engineering Laboratory, and minimum reporting levels..

8. Identification, source, and description of source-solution blanks and a trip blank for the water-quality monitoring program at the Idaho National Engineering Laboratory

9. Identification, source, and description of equipment blanks for the water-quality monitoring program at the Idaho National Engineering Laboratory

10. Comparison of results of replicate pairs of samples from the Idaho National Engineering Laboratory analyzed for sodium 
11. Comparison of results of replicate pairs of samples from the Idaho National Engineering

Laboratory analyzed for sulfate.

12. Comparison of results of replicate pairs of samples from the Idaho National Engineering Laboratory analyzed for chloride

13. Comparison of results of replicate pairs of samples from the Idaho National Engineering Laboratory analyzed for fluoride.

14. Comparison of results of replicate pairs of samples from the Idaho National Engineering Laboratory analyzed for bromide.

15. Comparison of results of replicate pairs of samples from the Idaho National Engineering Laboratory analyzed for nitrite, as nitrogen....

16. Comparison of results of replicate pairs of samples from the Idaho National Engineering Laboratory analyzed for nitrite plus nitrate, as nitrogen.

17. Comparison of results of replicate pairs of samples from the Idaho National Engineering Laboratory analyzed for ammonia and ammonia plus organic nitrogen, as nitrogen

18. Comparison of results of replicate pairs of samples from the Idaho National Engineering Laboratory analyzed for orthophosphate, as phosphorus; and phosphorus ....

19. Comparison of results of replicate pairs of samples from the Idaho National Engineering Laboratory analyzed for aluminum

20. Comparison of results of replicate pairs of samples from the Idaho National Engineering Laboratory analyzed for antimony.

21. Comparison of results of replicate pairs of samples from the Idaho National Engineering Laboratory analyzed for arsenic

22. Comparison of results of replicate pairs of samples from the Idaho National Engineering Laboratory analyzed for barium.

23. Comparison of results of replicate pairs of samples from the Idaho National Engineering Laboratory analyzed for beryllium. 45

24. Comparison of results of replicate pairs of samples from the Idaho National Engineering Laboratory analyzed for cadmium $5 C$

25. Comparison of results of replicate pairs of samples from the Idaho National Engineering Laboratory analyzed for chromium.

26. Comparison of results of replicate pairs of samples from the Idaho National Engineering Laboratory analyzed for cobalt 54

27. Comparison of results of replicate pairs of samples from the Idaho National Engineering Laboratory analyzed for copper . 55

28. Comparison of results of replicate pairs of samples from the Idaho National Engineering Laboratory analyzed for iron. 56 
29. Comparison of results of replicate pairs of samples from the Idaho National Engineering Laboratory analyzed for lead.....

30. Comparison of results of replicate pairs of samples from the Idaho National Engineering Laboratory analyzed for manganese

31. Comparison of results of replicate pairs of samples from the ldaho National Engineering Laboratory analyzed for mercury

32. Comparison of results of replicate pairs of samples from the Idaho National Engineering Laboratory analyzed for molybdenum

33. Comparison of results of replicate pairs of samples from the ldaho National Enginecring Laboratory analyzed for nickel

34. Comparison of results of replicate pairs of samples from the ldaho National Enginecring Lahoratory analyzed for sclenium

35. Comparison of results of replicate pairs of samples from the Idaho National Engincering Laboratory analyzed for silver

36. Comparison of results of replicate pairs of samples from the ldaho National Enginecring Laboratory analyzed for thallium

37. Comparison of results of replicate pairs of samples from the Jdaho National Enginecring Laboratory analyzed for uranium

38. Comparison of results of replicate pairs of samples from the ldaho National Engineering Laboratory analyzed for zinc.

39. Comparison of the results of replicate pairs of samples from the Idaho National Enginecring Laboratory analyzed for gross alpha radioactivity by the National Water Quality Laboratory .... 67

40. Comparison of the results of replicate pairs of samples from the Idaho National Engineering Laboratory analyzed for gross alpha radioactivily by the Radiological and Envirommental Sciences Laboratory

41. Comparison of the results of replicate pairs of samples from the ldaho National Enginecring Laboratory analyzed for gross bela radioactivity by the National Water Quality Laboratory

42. Comparison of the results of replicate pairs of samples from the ldaho National Engineering Laboratory analyzed for gross heta radioactivity by the Radiological and Environmental Sciences Laboratory

43. Comparison of the results of replicate pairs of samples from the Idaho National Enginecring Laboratory analyzed for gamma radiation

44. Comparison of the results of replicate pairs of samples from the Idaho National Engineering Laboratory analyzed for strontium-9().

45. Comparison of the results of replicate pairs of samples from the Idaho National Engineering Laboratory analyzed for tritium 
46. Comparison of the results of replicate pairs of samples from the Idaho National Engineering Laboratory analyzed for transuranics (americium-241, plutonium-238, and plutonium-239/240)

47. Comparison of results of replicate pairs of samples from the Idaho National Engineering Laboratory analyzed for total organic carbon

48. Comparison of results of replicate pairs of samples from the Idaho National Engineering Laboratory analyzed for volatile organic compounds....

49. Results of source-solution blanks, a trip blank, and equipment blanks from the Idaho National Engineering Laboratory analyzed for sodium, sulfate, chloride, fluoride, and chromium 81

50. Results of a source-solution blank, a trip blank, and an equipment blank from the Idaho National Engineering Laboratory analyzed for nitrite, nitrite plus nitrate, ammonia, as nitrogen; orthophosphate, as phosphorus; and total organic carbon.

51. Results of source-solution blanks and equipment blanks from the Idaho National Engineering Laboratory analyzed for gamma radiation, strontium- 90 , and tritium .

52. Results of an equipment blank from the Idaho National Engineering Laboratory analyzed for bromide; trace elements: iron, lead, mercury, nickel, and silver; and gross radioactivity ...... 84

53. Upper-tail areas for a normal curve .85

54. Site identifiers and sampling dates for replicate pairs of samples from the Idaho National Engineering Laboratory analyzed for volatile organic compounds

55. Volatile organic compounds with Chemical Abstracts Service (CAS) Registry numbers, and minimum reporting levels.

\section{CONVERSION FACTORS AND ABBREVIATED UNITS}

\begin{tabular}{llc}
\hline \multicolumn{1}{c}{ To convert from } & \multicolumn{1}{c}{ To } & Multiply by \\
\hline liter $(\mathrm{L})$ & gallon (gal) & 0.2207 \\
gram $(\mathrm{gr})$ & ounce $(\mathrm{oz})$ & .0353 \\
kilometer $(\mathrm{km})$ & mile $(\mathrm{mi})$ & .6214 \\
picocurie $(\mathrm{pCi})$ & decompositions per minute $(\mathrm{dpm})$ & 2.22 \\
degree Celsius $\left({ }^{\circ} \mathrm{C}\right)$ & degree Fahrenheit $\left({ }^{\circ} \mathrm{F}\right)$ & $\left({ }^{1}\right)$ \\
\hline
\end{tabular}

${ }^{1} \mathrm{Temp}{ }^{\circ} \mathrm{C}=\left(\right.$ temp $\left.{ }^{\circ} \mathrm{C}-32\right) / 1.8$.

Abbreviated units used in report: $\mathrm{mL}$ (milliliter); $\mathrm{L}$ (liter); $\mu \mathrm{g} / \mathrm{L}$ (microgram per liter); $\mathrm{mg} / \mathrm{L}$ (milligram per liter); pCi/L (picocur per liter). 


\title{
Evaluation of the Quality Assurance/Quality Control Data Collected by the U.S. Geological Survey for Water-Quality Activities at the Idaho National Engineering Laboratory, Idaho, 1994 through 1995
}

\author{
by Linda M. Williams
}

\section{Abstract}

More than 4,000 water samples were collected by the U.S. Geological Survey (USGS) from 179 monitoring sites for the water-quality monitoring program at the Idaho National Engineering Laboratory from 1994 through 1995. Approximately 500 of the water samples were replicate or blank samples collected for the quality assurance/ quality control program. Analyses were performed to determine the concentrations of major ions, nutrients, trace elements, gross radioactivity and radionuclides, total organic carbon, and volatile organic compounds in the samples.

To evaluate the precision of field and laboratory methods, analytical results of the replicate pairs of samples were compared statistically for equivalence on the basis of the precision associated with each result. In all, the statistical comparison of the data indicated that 95 percent of the replicate pairs were equivalent. Within the major ion analyses, 97 percent were equivalent; nutrients, 88 percent; trace elements, 95 percent; gross radioactivity and radionuclides, 93 percent; and organic constituents, 98 percent. Ninety percent or more of the analytical results for each constituent were equivalent, except for nitrite, orthophosphate, phosphorus, aluminum, iron, strontium-90, and total organic carbon.

Blank-sample analytical results indicated that the inorganic blank water and volatile organic compound blank water from the USGS National Water Quality Laboratory and the deionized water from the USGS Idaho Falls Field Office were suitable source solutions for blanks. Equipmentand trip-blank analytical results were evaluated to determine if a bias had been introduced and the possible sources of bias. The results indicated that none of the blanks had measurable concentrations of the constituents of interest, except one equipment blank that had measurable concentrations of total organic carbon, gross radioactivity, and tritium.

\section{INTRODUCTION}

The Idaho National Engineering Laboratory (INEL) includes approximately $890 \mathrm{mi}^{2}$ of the eastern Snake River Plain in southeastern Idaho (fig. 1). The INEL was established in 1949 as the National Reactor Testing Station for nuclearreactor research. The U.S. Department of Energy (DOE) continues the reactor research along with numerous other projects, including defense programs and environmental and waste remediation and research. These activities have produced aqueous radioactive and chemical wastes that hav? been discharged into ponds and wells. Prior to 1984, most of the aqueous radioactive and chemical wastes generated at the INEL were injected directly into the Snake River Plain aquifer through deep wells. Since 1984, most of the aqueous wastes have been discharged to unlined infiltration ponds. Many of the waste constituents have entered the aquifer after percolation through the unsaturated zone. The U.S. Geological Survey (USGS) conducts an extensive, ongoing waterquality monitoring program at 179 ground- and surface-water sites at the INEL in cooperation with the DOE. This program monitors effects of the waste disposal on the Snake River Plain aquifer. The information is provided to and used by many Federal and State government agencies, and the general public. 


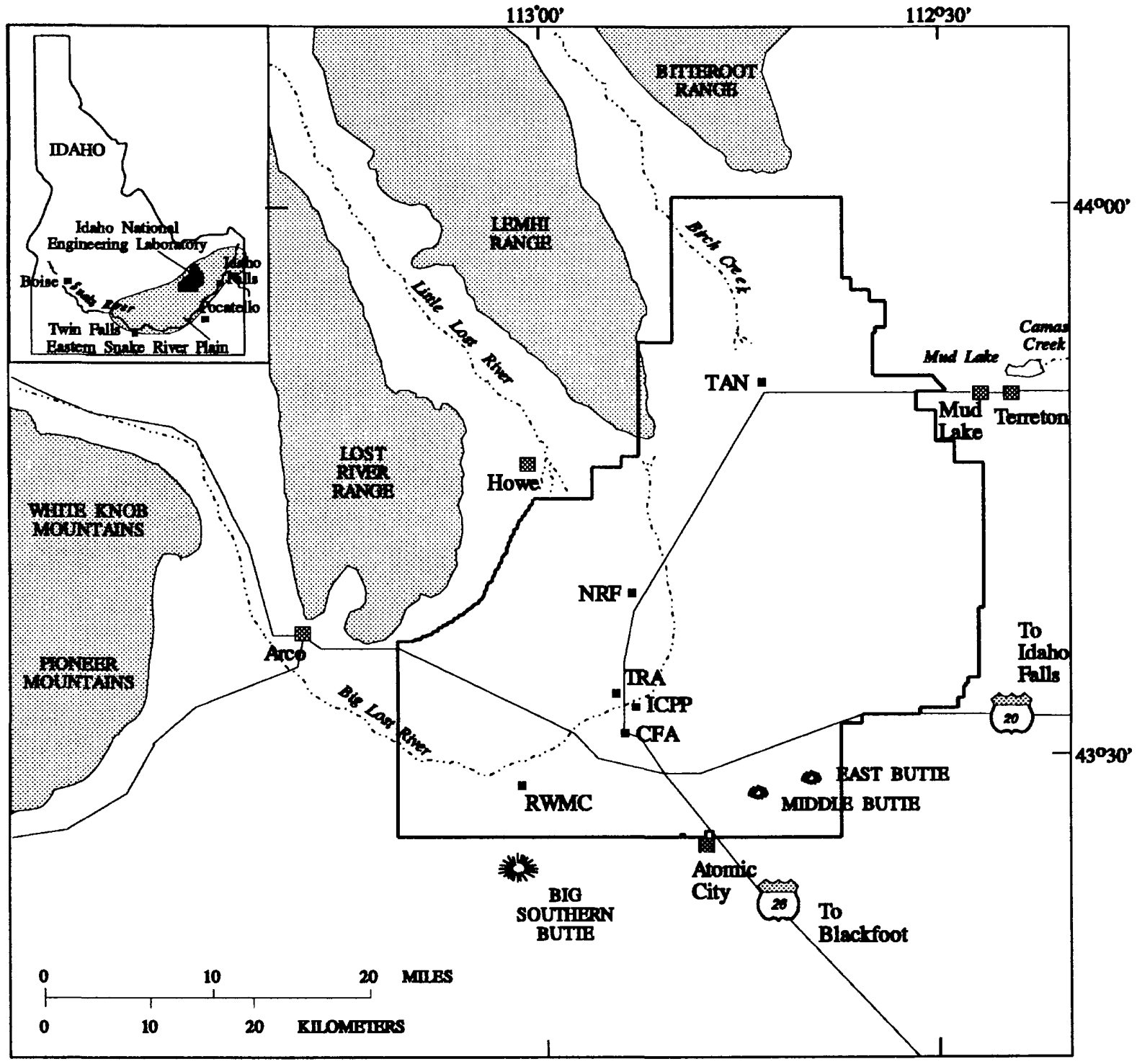

EXPLANATION

- Boundary of the Idaho National Engineering Laboratory

- Selected facilities at the Idaho National Enginecring Laboratory

$\begin{array}{ll}\text { CFA } & \text { Central Facilities Area } \\ \text { ICPP } & \text { Idaho Chemical Processing Plant } \\ \text { NRF } & \text { Naval Reactors Facility } \\ \text { RWMC } & \text { Radioactive Waste Management Complex } \\ \text { TAN } & \text { Test Area North } \\ \text { TRA } & \text { Test Reactor Area }\end{array}$

Figure 1. Location of the Idaho National Engineering Laboratory and facilities where ground-water samples were collected for the quality assurance/quality control program, Idaho National Engineering Laboratory, 1994 through 1995 
Table 1. Laboratories and respective analyses performed for the water-quality monitoring program at the Idaho National Engineering Laboratory

[Abbreviation: WWR, whole water, recoverable]

\begin{tabular}{lc}
\hline Laboratory & Quantitative analysis performed \\
\hline National Water Quality Laboratory & $\begin{array}{c}\text { Inorganic constituents: major ions, dissolved (sodium, sulfate, chloride, fluoride, } \\
\text { and bromide) and WWR sodium; nutrients, dissolved (nitrite, nitrite plus } \\
\text { nitrate, ammonia, and orthophosphate) and WWR (ammonia plus organic } \\
\text { nitrogen and phosphorus); trace elements, dissolved and WWR (aluminum, } \\
\text { antimony, arsenic, barium, beryllium, cadmium, chromium, copper, iron, lead, } \\
\text { manganese, mercury, nickel, silver, and zinc), dissolved (cobalt, molybdenum, } \\
\text { selenium, thallium, and uranium), and WWR iron }\end{array}$ \\
Gross radioactivity and radionuclides: gross alpha, gross beta, and tritium \\
Organic constituents: total organic carbon and volatile organic compounds \\
Gross radioactivity and radionuclides: gross alpha, gross beta, gamma radiation, \\
strontium-90, tritium, and transuranics (americium-241, plutonium-238, and \\
plutonium-239/240)
\end{tabular}

\section{Purpose and Scope}

The purpose of this report is to present an evaluation of the quality assurance/quality control (QA/QC) data from the water-quality monitoring program conducted by the USGS at the INEL. Approximately 4,000 water samples were collected for analysis from 1994 through 1995; more than 500 of those were replicate or blank samples (QA samples). Analytical results of the replicate pairs of samples are reported and compared for statistical equivalence. The replicate-pair analytical data and the results of the comparisons are compiled and tabulated along with the source-solution, trip- and equipment-blank analytical data. Evaluation of the results of the QA samples helps to assess precision and bias both in the field and in the laboratory. This evaluation not only validates the methods and procedures used at the INEL Project Office, but it also allows for planning future QA/QC efforts.

Included in this report is a brief description of the methods and procedures used by field personnel for collection of replicate pairs of samples and preparation of blanks. Locations of sampling sites and site identifiers are shown on figures 1 through 3. The laboratories involved in the project were the USGS National Water Quality Laboratory (NWQL) in Arvada, Colo., and the DOE Radiological and Environmental Sciences Laboratory (RESL) at the INEL. The laboratories and their respective analyses are listed in table 1. The inorganic constituent analyses included dissolved major ions; dissolved and whole water, recoverable (WWR) ${ }^{1}$ nutrients; and dissolved and WWR trace elements. The gross radioactivity and radionuclide analyses included gross alpha radioactivity, gross beta radioactivity, gamma radiation, strontium-90, tritium, and transuranics. Analyses of organic constituents included total organic carbon and volatile organic compounds.

\footnotetext{
${ }^{1}$ Whole water, recoverable (WWR) pertains to the constituents in solution after an unfiltered representative water-suspended-sediment sample is digested (usually using a dilute acid solution). Complete dissolution of the particulate matter often is not achieved by the digestion treatment, and thus the determination represents something less than the "total" amount (that is, less than 95 percent) of the constituent present in the dissolved and suspended phases of the sample. For inorganic determinations, digestions are performed in the original sample container to ensure digestion of material absorbed on the container walls. To achieve comparability of analytical data, equivalent digestion procedures would be required of all laboratories performing such analyses because different digestion procedures are likely to produce different analytical results (Timme, 1995, p. 95).
} 


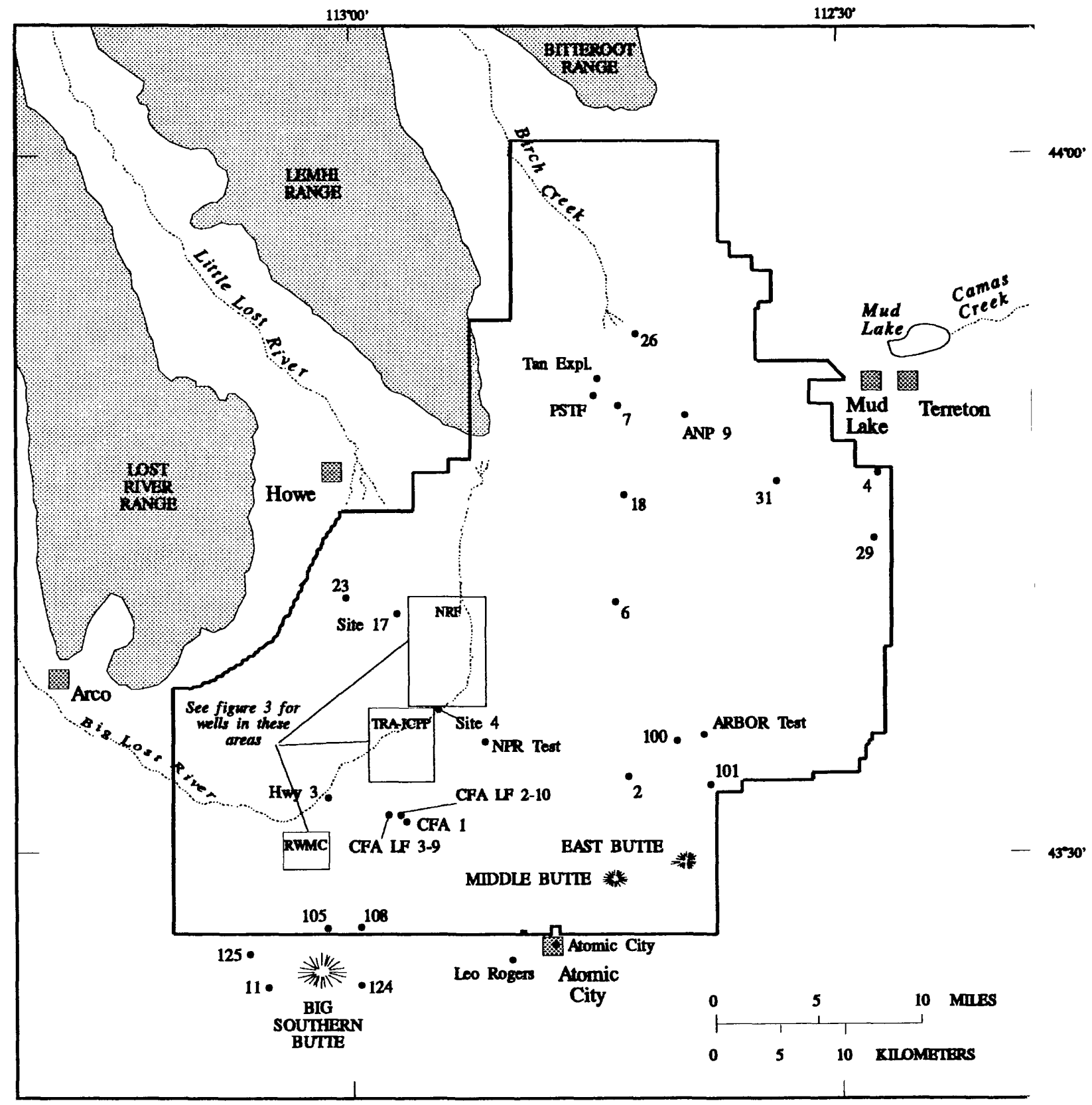

EXPLANATION

- Boundary of Idaho National Engineering Laboratory

11 - Well completed in the Snake River Plain aquifer--Entry, 11, is the local well identifier In text and on tables, numerical site identifiers are designated as USGS $n$

Figure 2. Locations of wells where ground-water samples were collected for the quality assurance/quality control program, Idaho National Engineering Laboratory, 1994 through 1995 


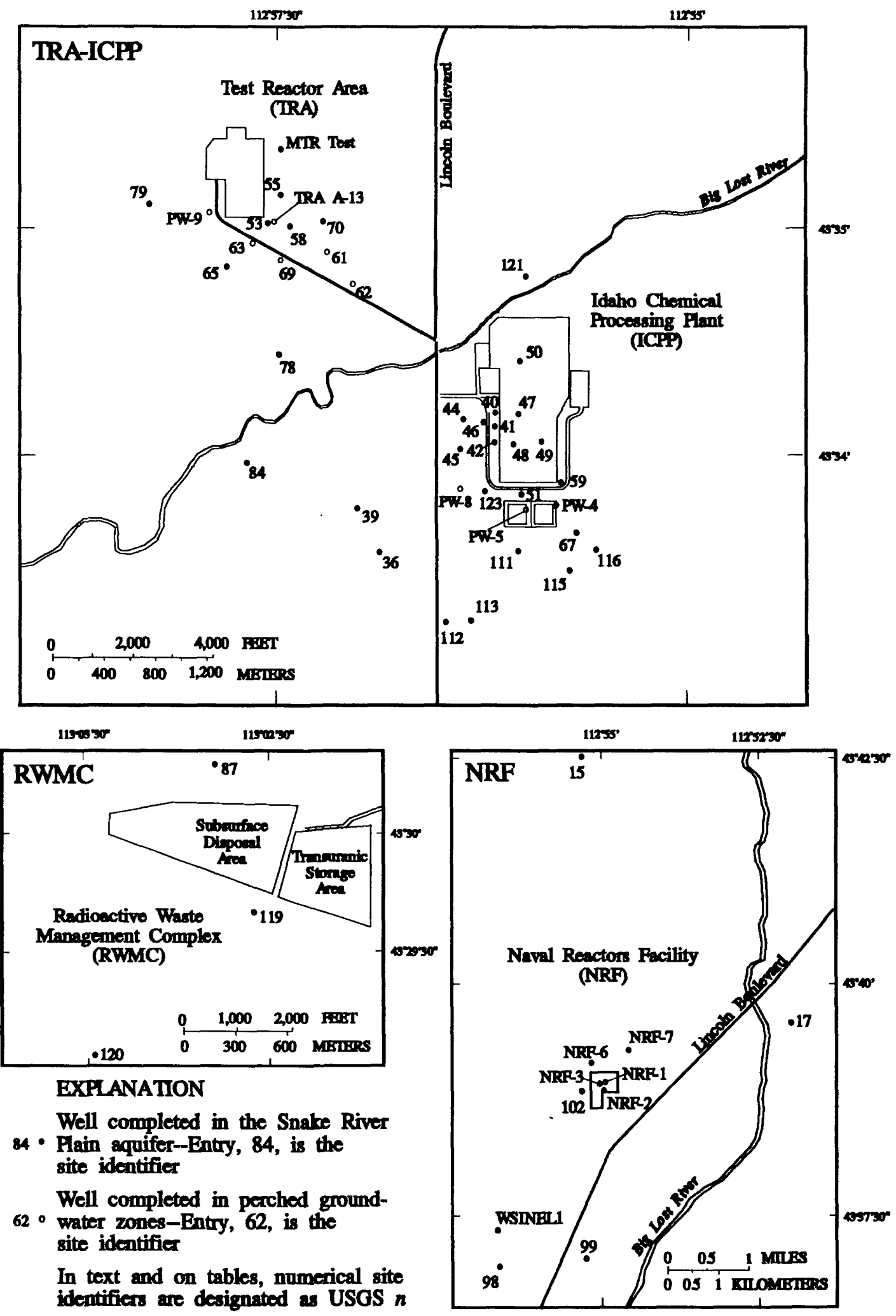

Figure 3. Locations of wells at the Test Reactor Area, Idaho Chemical Processing Plant (TRA-ICPP), Radioactive Waste Management Complex (RWMC), and Naval Reactors Facility (NRF) where ground-water samples were collected for the quality assurance/quality control program, Idaho National Engineering Laboratory, 1994 through 1995 


\section{Acknowledgments}

The author thanks the employees of the USGS at the INEL Project Office and at the NWQL and the employees of DOE at the RESL who collected and analyzed the water samples described in this report. The author is especially grateful for the technical reviews by Amy Ludtke and Linda Davis of the USGS.

\section{QUALITY ASSURANCE/QUALITY CONTROL PRACTICES}

The USGS is committed to collecting water samples that are as representative of the sampling site as possible and to reporting reliable and reproducible data. Guidelines that are specific to the USGS activities at the INEL have been set forth in the Quality Assurance Plan and Field Methods for Quality of Water Activities (L.J. Mann, U.S. Geological Survey, written commun., 1992). This comprehensive plan defines the required procedures and tasks that are performed to ensure the reliability of water-quality data. It is available for inspection at the INEL Project Office. This plan is updated continually. A brief description of the procedures and tasks is included in this report.

Field personnel also participate in the National Field Quality Assurance Tests administered annually by the USGS (Erdmann and Thomas, 1985, p. 110-115). These tests are used to evaluate performance in making field measurements for $\mathrm{pH}$, specific conductivity, and alkalinity.

Part of the QA/QC program, from 1994 through 1995, consisted of collecting and sending replicate pairs of samples and blank samples to the laboratories for analysis of specific constituents. Analytical results for the replicate pairs of samples were compared for statistical equivalence; the analytical results and the statistical comparisons are presented in tables 10 through 48 in the Supplemental Information section at the end of this report. The blank-sample results were evaluated and the data are presented in tables 49 through 52 in the same section.

\section{Sample Containers and Preservatives}

Sample containers and preservatives were supplied by the NWQL in accordance with the laboratory requirements specified by the NWQL Services Catalogs (Timme, 1994; 1995). The laboratory's Quality Assurance/Quality Control Manual (Pritt and Raese, 1992) describes the praclices used to ensure that the containers are free of contamination. The NWQL receives the required containers from suppliers, tests for contamination, and cleans the containers according to written procedures. Sample preservatives, which are prepared by contract suppliers for the NWQL, also are tested according to written procedures prior to shipping to field personnel. Sample containers, preservatives, and treatments for specific constituents are listed in tables 2 through 4 .

\section{Decontamination Procedures}

Equipment used to collect water samples from monitoring wells may become contaminated during the collection of samples. Decontamination procedures are used to decontaminate the equipment prior to use. Most wells are equipped with dedicated submersible pumps and only the discharge lines are moved from well to well; therefore, these lines are rinsed thoroughly with deionized water, inside and outside, between sampling sites. Subsequent flushing with at least three borshole volumes of sample water further decontaminates the discharge lines. Because the concentrations of most contaminants are greatest in wells nearest disposal sites, the most distant wells are sampled first, minimizing the possibility of crosecontamination.

Wells not equipped with dedicaled pumps are sampled either with a bailer or a portable submersible pump. The hailer and portable pumps are washed with warm water and detergent and rinsed with deionized water prior to use. At the sampling site, the pumps also are flushed with at least three borehole volumes of sample water. 
Table 2. Sample containers and preservation methods for analyses of inorganic constituents in water samples from the Idaho National Engineering Laboratory

[Analyzing laboratory was the National Water Quality Laboratory. Abbreviation: WWR, whole water, recoverable; $\mathrm{mL}$, milliliter. Excep ${ }^{\dagger}$ where noted, acidified samples were preserved with nitric acid to 0.4 percent, volume per volume]

\begin{tabular}{|c|c|c|}
\hline Inorganic constituents & Container size and type & Preservation method \\
\hline \multicolumn{3}{|c|}{ Major ions } \\
\hline $\begin{array}{l}\text { Sodium, dissolved } \\
\text { Sodium, }^{1} \\
W^{1}{ }^{1}\end{array}$ & $\begin{array}{l}250-\mathrm{mL} \text { polyethylene } \\
250-\mathrm{mL} \text { polyethylene }\end{array}$ & $\begin{array}{l}\text { Filtered, acidified } \\
\text { Acidified }\end{array}$ \\
\hline $\begin{array}{l}\text { Sulfate, dissolved } \\
\text { Chloride, dissolved } \\
\text { Fluoride, dissolved } \\
\text { Bromide, dissolved }\end{array}$ & 250-mL polyethylene & Filtered \\
\hline \multicolumn{3}{|c|}{ Nutrients } \\
\hline $\begin{array}{l}\text { Nutrients, dissolved (ammonia, nitrite, } \\
\text { nitrate plus nitrite, and orthophosphate) }\end{array}$ & 125-mL brown polyethylene & $\begin{array}{l}\text { Filtered, preserved with } 0.5 \mathrm{~mL} \text { of } \\
\text { mercuric chloride and chilled or } \\
\text { chilled only }{ }^{2}\end{array}$ \\
\hline Nitrite, dissolved ${ }^{3}$ & 125-mL brown polyethylene & Filtered and chilled \\
\hline Nitrate plus nitrite, dissolved & $125-\mathrm{mL}$ brown polyethylene & $\begin{array}{l}\text { Filtered, preserved with } 1 \mathrm{~mL} \text { of sulfuric } \\
\text { acid and chilled }\end{array}$ \\
\hline $\begin{array}{l}\text { Ammonia plus organic nitrogen, WWR } \\
\text { Phosphorus, WWR }\end{array}$ & $125-\mathrm{mL}$ brown polyethylene & $\begin{array}{l}\text { Preserved with } 1 \mathrm{~mL} \text { of sulfuric acid } \\
\text { and chilled }\end{array}$ \\
\hline \multicolumn{3}{|c|}{ Trace elements } \\
\hline $\begin{array}{l}\text { Trace elements, dissolved } \\
\text { Trace elements, WWR }\end{array}$ & $\begin{array}{l}250-\mathrm{mL} \text { polyethylene } \\
250-\mathrm{mL} \text { polyethylene }\end{array}$ & $\begin{array}{l}\text { Filtered, acidified } \\
\text { Acidified }\end{array}$ \\
\hline $\begin{array}{l}\text { Chromium, dissolved }{ }^{1} \\
\text { Chromium, hexavalent, dissolved }^{4} \\
\text { Chromium, WWR }^{1}\end{array}$ & $\begin{array}{l}\text { 250-mL polyethylene } \\
250-\mathrm{mL} \text { polyethylene } \\
250-\mathrm{mL} \text { polyethylene }\end{array}$ & $\begin{array}{l}\text { Filtered, acidified } \\
\text { Filtered, acidified } \\
\text { Acidified }\end{array}$ \\
\hline Mercury, dissolved & 250-mL glass & $\begin{array}{l}\text { Filtered, preserved with } 10 \mathrm{~mL} \text { of } \\
\text { potassium dichromate }\end{array}$ \\
\hline Mercury, WWR & 250 -mL glass & $\begin{array}{l}\text { Preserved with } 10 \mathrm{~mL} \text { of } \\
\text { potassium dichromate }\end{array}$ \\
\hline
\end{tabular}

${ }^{1}$ The dissolved sodium sample also may be used for the dissolved chromium analysis, and the WWR sodium sample for the WWR chromium analysis.

${ }^{2}$ Prior to October, 1994, samples were filtered and preserved with $0.5 \mathrm{~mL}$ of mercuric chloride and chilled. Presently, mercuric chloride is not used and samples are filtered and chilled only.

${ }^{3}$ When nutrient samples must be acidified with sulfuric acid, an unacidified nitrite sample is prepared separately.

${ }^{4}$ The dissolved chromium and dissolved hexavalent chromium samples may be collected in one bottle. 
Table 3. Sample containers and preservation methods for analyses of gross radioactivity and radionuclides in water samples from the Idaho National Engineering Laboratory

[Abbreviations: RESL, Radiological and Environmental Sciences Laboratory; NWQL, National Water Quality Laboratory; mL, millilit .r; $L$, liter. Except where noted, acidified samples were preserved with nitric acid to 0.4 percent, volume per volume]

\begin{tabular}{|c|c|c|c|}
\hline $\begin{array}{l}\text { Gross radioactivity } \\
\text { or radionuclide }\end{array}$ & Laboratory & Container size and type & Preservation method \\
\hline Gross alpha & RESL & 500 -mL polyethylene & Acidified \\
\hline Gross alpha, dissolved & NWQL & 1-L polyethylene & Filtered, acidified \\
\hline $\begin{array}{l}\text { Gross alpha, dissolved and } \\
\text { suspended }\end{array}$ & NWQL & 1-L polyethylene & Untreated \\
\hline Gross beta & RESL & $500-\mathrm{mL}$ polyethylene & Acidified \\
\hline Gross heta, dissolved & NWQL & 1-L polyethylene & Filtered, acidified \\
\hline $\begin{array}{l}\text { Gross heta, dissolved and } \\
\text { suspended }\end{array}$ & NWQL & 1-L polyethylene & Untreated \\
\hline Gamma radiation & RESL & $500-\mathrm{mL}$ polyethylene & Acidified \\
\hline Strontium-90 & RESL & $500-\mathrm{mL}$ polyethylene & Acidified \\
\hline Tritium & $\begin{array}{l}\text { RESL } \\
\text { NWQL }\end{array}$ & $\begin{array}{l}125-\mathrm{mL} \text { or } 500-\mathrm{mL} \text { polyethylene } \\
250-\mathrm{mL} \text { or } 1-\mathrm{L} \text { polyethylene }\end{array}$ & $\begin{array}{l}\text { Untreated } \\
\text { Untreated }\end{array}$ \\
\hline $\begin{array}{l}\text { Americium-241 } \\
\text { Plutonium-238 } \\
\text { Plutonium-239/240 }\end{array}$ & RESL & $500-\mathrm{mL}$ polyethylene & Acidified \\
\hline
\end{tabular}

Table 4. Sample containers and preservation methods for analyses of organic constituents in water samples from the Idaho National Engineering Laboratory

[Analyzing laboratory was the National Water Quality Laboratory. Abbreviations: $\mathrm{mL}$, milliliter]

\begin{tabular}{lll}
\hline \multicolumn{1}{c}{ Organic constituent } & Container size and type & Preservation method \\
\hline Total organic carbon & $125-\mathrm{mL}$ amber glass & Chilled \\
Volatile organic compounds & 40 -mL amber glass septum vials & Chilled \\
& & \\
\hline
\end{tabular}

All measuring and sampling equipment that comes into contact with the sample water is thoroughly rinsed with deionized water prior to use. The thermometers, probes, and electrodes of the $\mathrm{pH}$ meters and the specific conductivity meters are rinsed with deionized water and rinsed again with sample water so that when measurements are made, the deionized water will not dilute the sample. Disposable latex gloves are wom, and changed when needed, to ensure that the samples are not contaminated by the field personnel themselves or cross-contaminated by preservatives or previous samples. Unless otherwise specified for a particular analysis or type of container, all the containers are rinsed with sample water, either filtered or unfiltered, as appropriate. To minimize the possibility of contamination, totally enclosed disposable capsule filters are used for filtration. Flexible tubing that connects the capsule filter to the sampling port at the well or to the peristaltic pump is thoroughly washed with water and detergent and rinsed with deionized water befor? use. 


\section{Sample Collection}

The guidelines for water sample collection are being updated continually in accordance with new safety and environmental regulations and to accommodate the requirements of improved analytical procedures. Guidelines for field treatment of sample containers are specified in the NWQL Services Catalog (Timme, 1994; 1995). When field rinsing is required, the sample conlainers are rinsed three times with sample or deionized water before filling. The samples are untreated; or filtered, preserved, and chilled as established by the NWQL (Timme, 1994; 1995) or in the manner recommended by RESL (Olson and Percival, 1980, p. SP-1-1) depending on the analyses requested. Although some sample collection procedures changed from 1994 through 1995, each sample of a replicate pair was always collected in the same manner.

Most samples are collected from wells with dedicated submersible pumps. Wells without dedicated pumps are sampled with bailers or portable pumps. Grab samples are collected at the seven surface-water sites.

The INEL Project Office maintains mobile field laboratories in which the supplies and equipment necessary for sampling are available for immediate sample processing. Field measurements are taken in this relatively clean and protected environment, and samples are preserved and prepared for shipping without delay.

At the INEL, steps are taken to make certain that the water samples are representative of the ground water at the sampling site. To achieve this, a volume of water equivalent to a minimum of three borehole volumes is pumped from each well. In addition, the temperature, $\mathrm{pH}$, and specific conductivity are monitored during pumping, using methods described by Wood (1981) and Hardy and others (1989). When the wells have been purged and measurements of these properties indicate probable hydraulic and chemical stability, field personnel collect the samples. Some wells do not contain or produce enough water to be purged three borehole volumes, so samples are collected from the bailer as soon as the temperature, $\mathrm{pH}$, and specific conductivity measurements stabilize.
When filtration is required, disposable capsule filters are connected directly to the portable discharge line by flexible tubing. At the few sites where a bailer is used or where grab samples are collected, the filters are connected to a peristaltic pump. The intake tubing of the peristaltic pump is rinsed with sample water and inserted into the cortainer. Regardless of the filtering technique, 1 liter of sample water is run through the capsule filter and tubing before the sample bottle is rinsed and filled. If the water at the sampling site contains large amounts of suspended material, it may be necessary to rinse the filter with 1 liter of deionized water, rather than with sample water, before the container is rinsed and filled. The containers are then capped and transported into the field laboratory for preservation. After the sample is preserved, the containers are recapped and labeled, and the caps are sealed with laboratory film.

To minimize analyte loss by biological processes or volatilization, samples for nutrient and organic constituent analyses are chilled to approximately $4^{\circ} \mathrm{C}$. The samples are kept on ice until they are received at the laboratory, where they are refrigerated.

All water samples are stored in the mobile field laboratory until they can be transferred to a secured storage area. After a sufficient number of samples is collected, and before any holding-time limitations have been exceeded, the samples are delivered to the appropriate laboratories for analyses. Holding-time limitations for the nutrients and organic constituents are 7 and 14 days, respectively. Samples for the NWQL are shipped by overnight-delivery mail in a sealed ice chest and usually are sent to the laboratory within 5 days of collection. The samples to be analyzed by the RESL are hand-carried to the analytical chemistry area.

Conditions during sample collection at the we"l or surface-water site are recorded with permanent ink in a bound field logbook at the sampling site. The containers are labeled at each location to avoir sample mix-up. A chain-of-custody form is used to track samples from the time of collection until delivery to the laboratory. These procedures were instituted in September 1987, and all records are available for inspection at the INEL Project Offic?. 


\section{Analytical Methods and Reporting of Data}

Methods of detection or instrumentation used by the laboratories for each type of analysis and their corresponding detection limits or MRL's are listed in tables 5 through 7.

Detection limits are used by the RESL. Because they are a function of sample matrix, sample size, and type of measurement, the limits are intended as guides to order-of-magnitude sensitivities and can easily change by a factor of two or even more for the conditions specified (Bodnar and Percival, 1982, p. DL-1-1). With each radiochemical result, the RESL reports a propagated random uncertainty that is calculated using many variables, including the yields, appropriate half-lives, counting efficiencies, and count times. This uncertainty is one standard deviation as defined on the RESL Sample Record Sheet (ID F-5484.1A, written commun., Rev. 12-1988).

The NWQL uses minimum reporting levels (MRL's), which are defined as the smallest measured concentration of a constituent that may' be reliably reported using a given analytical method and also are used when documentation for the method detection limit is not available (Timme, 1995). For radiochemical results only, the NWQ'. reports a result and a value twice the standard deviation. Therefore, when comparing the results of analyses of gross radioaclivity and radionuclides by the NWQL and the RESL, it is important to remember that two standard deviations are reported by the NWQL and one standard deviation is reported by the RESL.

Table 5. Analytical methods used to determine inorganic constituents in water samples from the Idaho National Engineering Laboratory, and minimum reporting levels

[Analyzing laboratory is the National Water Quality Laboratory. Abbreviations: MRL, minimum reporting level; $\mathrm{mg} / \mathrm{L}$, milligram per lifer; $\mu \mathrm{g} / \mathrm{L}$, microgram per liter]

\begin{tabular}{llc}
\hline \multicolumn{1}{c}{ Inorganic constituent } & Analytical method & MRL \\
\hline Sodium & Atomic absorption spectrometry & $0.1 \mathrm{mg} / \mathrm{L}$ \\
Sulfate & Ion-exchange chromatography & $0.1 \mathrm{mg} / \mathrm{L}$ \\
Chloride & Ion-exchange chromatography & $0.1 \mathrm{mg} / \mathrm{L}$ \\
Fluoride & Ion selective electrode & $0.1 \mathrm{mg} / \mathrm{L}$ \\
Bromide & Ion-exchange chromatography & $0.01 \mathrm{mg} / \mathrm{L}$ \\
Nutrients & Automated-segmented flow, colorimetry & $0.01-0.2 \mathrm{mg} / \mathrm{L}^{1}$ \\
Trace elements & Atomic absorption spectrometry & $1-10 \mu \mathrm{g} / \mathrm{L}^{1}$ \\
& Inductively coupled plasma-Atomic emission spectrometry & $1-10 \mu \mathrm{g} / \mathrm{L}^{1}$
\end{tabular}

${ }^{1}$ Multiple MRL's are dependent upon the constituent. 
Table 6. Analytical methods used to determine gross radioactivity and radionuclides in water samples from the Idaho National Engineering Laboratory, and detection limits or minimum reporting levels

[Abbreviations: MRL, minimum reporting level; RESL, Radiological and Environmental Sciences Laboratory; NWQL, National Water Quality Laboratory; $\mathrm{pCi} / \mathrm{L}$, picocurie per liter; $\mu \mathrm{g} / \mathrm{L}$, microgram per liter]

\begin{tabular}{|c|c|c|c|}
\hline $\begin{array}{l}\text { Gross radioactivity } \\
\text { or radionuclide }\end{array}$ & Laboratory & Analytical method & $\begin{array}{l}\text { Detection limit } \\
\quad \text { or MRL }\end{array}$ \\
\hline Gross alpha & $\begin{array}{l}\text { RESL } \\
\text { NWQL }\end{array}$ & $\begin{array}{l}\text { Scintillation } \\
\text { Low background alpha-beta counter }\end{array}$ & $\begin{array}{l}3 \mathrm{pCi} / \mathrm{L} \\
3 \mathrm{pCi} / \mathrm{L} \\
3 \mu \mathrm{g} / \mathrm{L}\end{array}$ \\
\hline Gross beta & $\begin{array}{l}\text { RESL } \\
\text { NWQL }\end{array}$ & $\begin{array}{l}\text { Low background beta counter } \\
\text { Low background alpha-beta counter }\end{array}$ & $\begin{array}{l}5 \mathrm{pCi} / \mathrm{L} \\
3-4 \mathrm{pCi} / \mathrm{L}^{2}\end{array}$ \\
\hline Gamma radiation & RESL & Gamma spectroscopy & $60 \mathrm{pCi} / \mathrm{L}$ \\
\hline Strontium-90 & RESL & Low background beta counter & $5 \mathrm{pCi} / \mathrm{L}$ \\
\hline Tritium & $\begin{array}{l}\text { RESL } \\
\text { NWQL }\end{array}$ & $\begin{array}{l}\text { Liquid scintillation } \\
\text { Enrichment, gas counting }\end{array}$ & $\begin{array}{l}200 \mathrm{pCi} / \mathrm{L} \\
0.1 \mathrm{pCi} / \mathrm{L}\end{array}$ \\
\hline Americium-241 & RESL & Alpha spectrometry & $6 \times 10^{-2} \mathrm{pCi} / \mathrm{L}$ \\
\hline Plutonium-238 & RESL & Alpha spectrometry & $4 \times 10^{-2} \mathrm{pCi} / \mathrm{L}$ \\
\hline Plutonium-239/240 & RESL & Alpha spectrometry & $4 \times 10^{-2} \mathrm{pCi} / \mathrm{L}$ \\
\hline
\end{tabular}

${ }^{1}$ The RESL uses detection limits and the NWQL uses MRL's.

${ }^{2}$ For gross beta radioactivity analyses by the NWQL, the MRL was lowered from $4 \mathrm{pCi} / \mathrm{L}$ in 1994 to 3 pCi/L in 1995.

Table 7. Analytical methods used to determine organic constituents in water samples from the Idaho Nationa' Engineering Laboratory, and minimum reporting levels

[Analyzing laboratory is the National Water Quality Laboratory. Abbreviations: MRL, minimum reporting level; $\mathrm{mg} / \mathrm{L}$, milligram per liter; $\mu \mathrm{g} / \mathrm{L}$, microgram per liter]

\begin{tabular}{llc}
\hline \multicolumn{1}{c}{ Organic constituent } & Analytical method & MRL \\
\hline Total organic carbon & Wet oxidation & $0.1 \mathrm{mg} / \mathrm{L}$ \\
Volatile organic compounds & Gas chromatography/mass spectrometry & $0.2-20 \mu \mathrm{g} / \mathrm{L}^{1}$ \\
\hline
\end{tabular}

${ }^{1}$ Multiple MRL's are dependent upon the constituent. 


\section{QUALITY ASSURANCE/QUALITY CONTROL DATA, REPLICATE PAIRS OF SAMPLES}

Two methods were used for collecting replicate pairs of samples for the for the water-quality monitoring program at the INEL. For the first method, replicate pairs of samples were collected sequentially; that is, the routine water-quality sample was collected for a specific analysis, then the QA sample for that same analysis, until all the required containers were filled for all the scheduled analyses. There was no correlation between the identifier of the routine water-quality sample and QA sample; the field personnel selected a QA number sequentially during a sampling session and recorded that number in the field logbooks along with the required information about that particular site. Each QA sample was labeled and preserved at the sampling site along with the routine sample to avoid sample mix-up. This type of QA sample is useful in determining the laboratory's analytical reproducibility related to equipment, materials, or analysts.

Beginning in 1993, a second method was also used: replicate samples (the QA samples) were collected at the same site for the same constituents within 24 hours of the collection of the routine water-quality samples. This type of QA sample assesses variability related to the collection process, such as ambient conditions at the site, field personnel, field-measurement instruments, and sampling equipment.

\section{Statistical Comparisons of Replicate Pairs of Samples}

If the standard deviations are known, it is possible to determine, within a specified confidence level, whether the results of a replicate pair of samples are statistically equivalent. When the standard deviations are unknown, approximations of the standard deviations are used for the statistical comparison. The comparison can be done using an adaptation of the equation to determine the standard deviate, $\mathrm{Z}$, or the number of standard deviations the variable deviates from the mean (Volk, 1969, p. 55), where $\mathrm{Z}$ is the ratio of the absolute value of the difference of the two results and the square root of the sum of the squares of the? standard deviations (the pooled standard deviation). In that way, a comparison can be made of two analytical results on the basis of the precision, or an approximation of the precision, associated with each of the results:

$$
Z=\frac{|x-y|}{\sqrt{\left(s_{x}\right)^{2}+\left(s_{y}\right)^{2}}}
$$

where

$x$ is the result of the routine water-quality sample,

$y$ is the result of the QA sample,

$s_{x}$ is the standard deviation of $x$, and

$s_{y}$ is the standard deviation of $y$.

When the population is distributed normally and the standard deviation is known, the analytical results of replicate pairs can be considered statistically equivalent at the 95 -percent confidence leval if the $\mathrm{Z}$-value is less than or equal to 1.96 . When the population is not distributed normally or an approximation of the standard deviation is used, a Z-value less than or equal to 1.96 must be considered a guide when testing for equivalence. At the 95-percent confidence level, the probability of error is 0.05 . In other words, when a Z-value is less than or equal to 1.96 , the results are within approximately two standard deviations of each other.

Equation 1 is essentially the equation used to compare replicate data in the USGS protocol for collecting and processing surface-water samples (Horowitz and others, 1995, p. 36).

Instead of setting a value that is approximately equal to two standard deviations as a test of equivalence, the level of significance, or $p$-value, which indicates the weight of the evidence to reject the null hypothesis, $x \pm s_{x}=y \pm s_{y}$ may be determined. The null hypothesis is tested using the Z-value as the test statistic. The $Z$-value is calculated by using equation 1 , then the $p$-value is determined by referring to table 53 in the Supplemental Information section. Assuming the distribution is normal, the $p$-value is the area under the curve for the $\mathrm{Z}$-value. The greater the $\mathrm{Z}$-value, the smaller the $p$-value and the more likely that the results of the replicate pair are not equivalent, and the null hypothesis will be rejected. When $Z=1.96$, the $p$-value $=0.0250$ for a one-tailed test and 0.0500 for a two-tailed test (table 53). This shows that 
these $p$-values are equivalent to the 95-percent conlidence level and $\alpha=0$.(5), where $\alpha$ is the probability that the null hypothesis will be rejected when truc.

\section{Inorganic Constituents}

Equation 1 cannot be applied directly to results when no standard deviations or uncertainties are reported. The analyses for inorganic constituents, which were done at the NWQL, were not reported with standard deviations; therefore, approximations of standard deviations were used.

The USGS administers an extensive interlaboratory comparison program in which approximately 150 laboratories are evaluated hased on the results of their analyses of standard reference water samples (SRWS) (Long and Farrar, 1993). The data from the interlaboratory comparison program, or the SRWS program, are used by the USGS Branch of 'Technical Development and Quality Systems (BTD\&QS), formerly the Branch of Quality Assurance, 10 derive linear regression equations that allow the calculation of an approximation of the standard deviation, called a most probable deviation (MPD), at any concentration for most analyses.

The BTD\&QS conducts the Blind Sample Program (BSP) in which SRWS, disguised as environmental samples, are submitted to the NWQL for analysis. The BSP data are evaluated using control charts prepared with the MPD's calculated with the regression equations formulated from the SWRS program. A report by Maloney and others (199.3) describes the BSP. evaluates the analytical results, and presents the linear regression equations and control and precision charts. The BSP data and control and precision charts are stored in the QADATA program that is available through the USGS computer network (Lucey, 1990), p. 1).

At the INEL project office, the linear regression equations are used to determine if the analytical results of the replicatc pairs are statistically equivalcnt by calculating an MPD for each result and substiluting the MPD for the standard deviation in equation 1. Because these are approximate standard deviations, the $\mathrm{Z}$-value of 1.96 must be considered a guide when testing for equivalence. The results of the replicate pairs of the inorganic constituent analyses and the $Z$-values for each replicate pair are presented in tables 10 through 38 .

For many samples, the analytical results were less than the MRL. If the results of both samples of the replicate pair were less than the MRL, the results were considered equivalent and the $\mathrm{Z}$-value was reported as a zero. If, however, only one of the results was less than the MRL, one of two approaches was taken.

First, if one result was less than the MRL and the other exceeded the MRL, the numerical value and the MPD of the numerical value of the MRL were substituted in equation 1 for the result that was less than the MRL. For example, the analytical results of the barium analyses for the replicate pair collected at NRF-3 on June 8,1995 were $200 \mu \mathrm{g} / \mathrm{L}$ and $<100 \mu \mathrm{g} / \mathrm{L}$ (lable 22). Using the minimum MPD of $75 \mu \mathrm{g} / \mathrm{L}$ (Maloney and others, 1993, p. 5) that has been set for this analysis, the results and MPD were $2(1) \pm 75 \mu \mathrm{g} / \mathrm{L}$ and $<10() \pm 75 \mu \mathrm{g} / \mathrm{L}$, respectively. The $Z$-value, calculated with equation 1. equaled (1.94. It was less than 1.96; therefore, it was within the 95-percent confidence interval. The results of the replicale pair were equivalent and no comment appears in the column labeled "Remark." If the Z-value had been greater than 1.96 , an " $\mathrm{N}$ " would have appeared in the column labeled "Remark," signifying that the results were not equivalent.

Second, if one result was less than the MRL and the other was at the MRL, the MPD of the result was calculated at the MRL using the linear regression equation for that analysis. But, it is impractical to use equation 1 hecause the $Z$-value will always equal zero. Therefore, to compare the two results using the precision associated with them, the MPD was muttiplied by 1.96 . If the range of the MPD had included zero, the results would have been equivalent because any result less than the MRL was included in the 95-percent confidence interval. If the range had not included zero, as often is the case when the MPD is relatively small, equivalency could not be determined. For example, the analytical results for cadmium analyses of the replicate pair collected at NRF-6 on March 10, 1995 were $<1 \mu \mathrm{g} / \mathrm{L}$ and $1 \mu \mathrm{g} / \mathrm{L}$ (table 24). Using the minimum MPD of $0.75 \mu \mathrm{g} / \mathrm{L}$ 
(Maloney and others, 1993, p. 5) that has been set for this analysis, the results and MPD were $<1 \pm 0.75 \mu \mathrm{g} / \mathrm{L}$ and $1 \pm 0.75 \mu \mathrm{g} / \mathrm{L}$, respectively. Therefore, the result of $1 \mu \mathrm{g} / \mathrm{L}$ would have an MPD of $1.96 \times 0.75 \mu \mathrm{g} / \mathrm{L}$ at the 95 -percent confidence level: $1 \pm 1.47 \mu \mathrm{g} / \mathrm{L}$. The range included zero and no comment appears in the column labeled "Remark." If the range had not included zero, a "U" would have appeared in the column labeled "Remark," signifying that equivalence was uncertain.

\section{Gross Radioactivity and Radionuclides}

The use of equation 1 is straightforward in determining if the results of radiochemical analyses of a replicate pair of samples were equivalent. Because the NWQL reported radiochemical results and two standard deviations, it was necessary to divide the value by two to compute the one standard deviation required by equation 1 . The results and reported standard deviations for the analyses of gross radioactivity and radionuclides in replicate pairs and the Z-values are listed in tables 39 through 46. Calculations using equation 1 were performed on each replicate pair. If the analytical results of the pair were not statistically equivalent, an "N" appears in the column labeled "Remark."

\section{Organic Constituents}

Organic constituents were not included in the BSP. Therefore, the standard deviations for lotal organic carbon analyses were calculated from the relative standard deviations (RSD) reported by Wershaw and others (1987, p. 15-16). The standard deviations of the volatile organic compounds were calculated from the RSD's provided by Rose and Schroeder (1995, p. 18-23). The sites where replicate samples were collected for analyses of volatile organic compounds are listed in table 54; the volatile organic compounds, in table 55 . The results of the replicate pairs analyzed for total organic carbon and the three volatile organic compounds that were reported at or above the MRL's are included, along with the Z-values, in tables 47 through 48. If analytical results of the pair were not statistically equivalent, an " $N$ " appears in the column labeled "Remark." If the results of both samples of the replicate pair were less than the MRL, the results were considered equivalent and the $\mathrm{Z}$-value is reported as a zero.

\section{Summary of Statistical Comparisons of Replicate Pairs of Samples}

In all, the statistical comparisons of the data indicated that 95 percent of the replicate pairs were equivalent. Within the major ion analyses, 97 percent were equivalent; nutrients, 88 percent; trace elements, 95 percent; gross radioactivity and radionuclides, 93 percent; and organic constituents, 98 percent. Ninety percent or more of the analytical results for each constituent were equivalent, except for nitrite, orthophosphate, phosphorus, aluminum, iron, strontium-90, and total organic carbon. Lack of equivalence between results of replicate pairs indicates a problem. Because many factors, such as field methods, ambient condition , laboratory procedures, and nonanalytical errors can affect precision, the source of the inconsistency cannot always be determined.

The following sections summarize the statistical comparisons for each constituent. Graphical summaries are provided in figures 4 through 8.

\section{Inorganic Constituents}

Major ions.-Several replicate pairs of samples were analyzed by the NWQL for dissolved major ions. The major ions and the number of replicate pairs follow: sodium, 64; sulfate, 31 ; chloride, 99; fluoride, 12; and bromide, 11. For all but the bromide analyses, the Z-values were calculated with the analytical results and the MPD's determined with the regression equations formulated by the BTD\&QS from the SRWS program data. Because the bromide analysis is not included in the BSP, an RSD of 15 percent (Pritt and Jones, 1989, p. 5-6) was used in equation 1.

Major ions analyzed and percentages of the analytical results of the replicate pairs that were equivalent follow: sodium, 95 percent; sulfate, 100 percent; chloride, 98 percent; fluoride, 100 percent; and bromide, 91 percent. The Z-values 


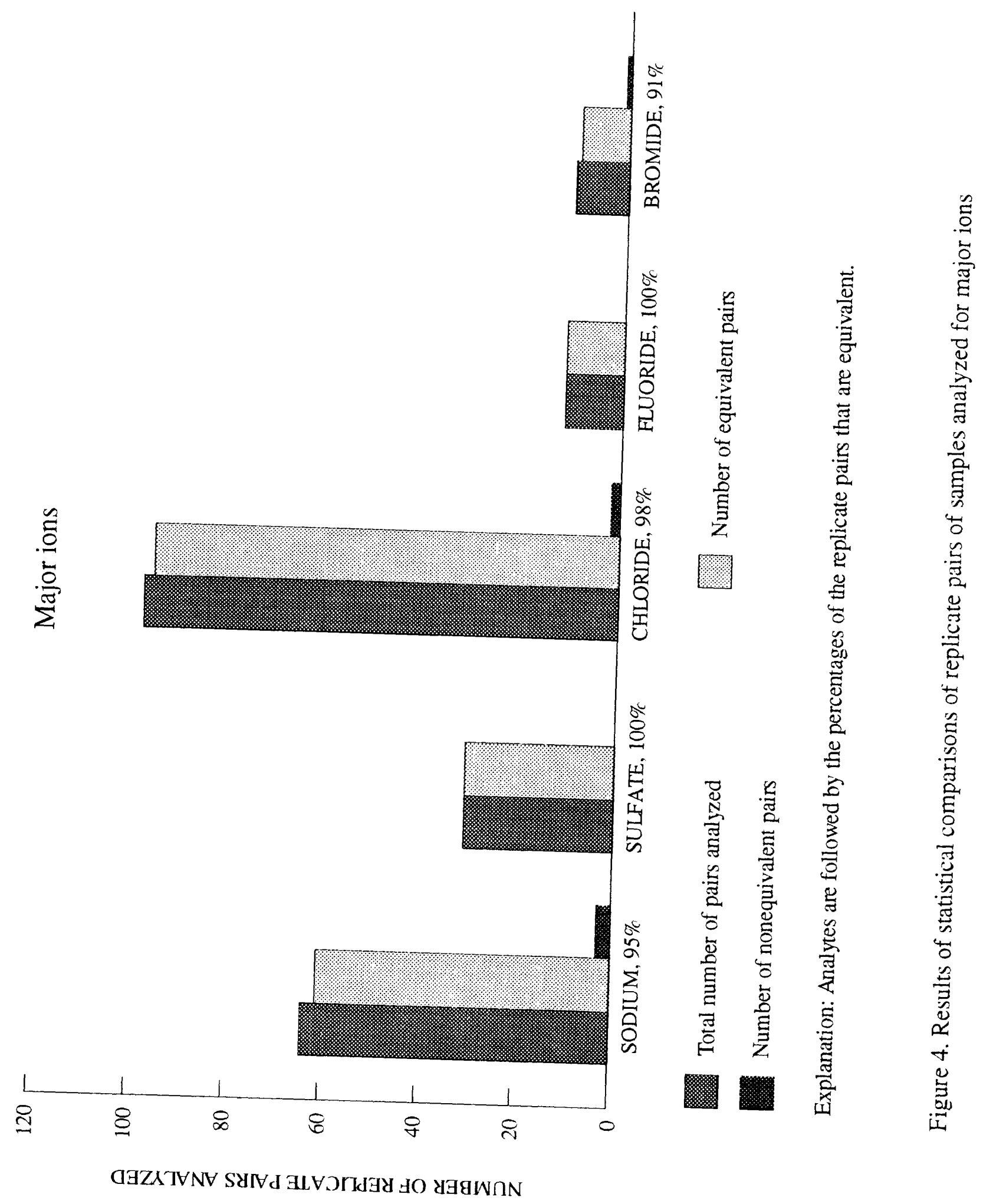




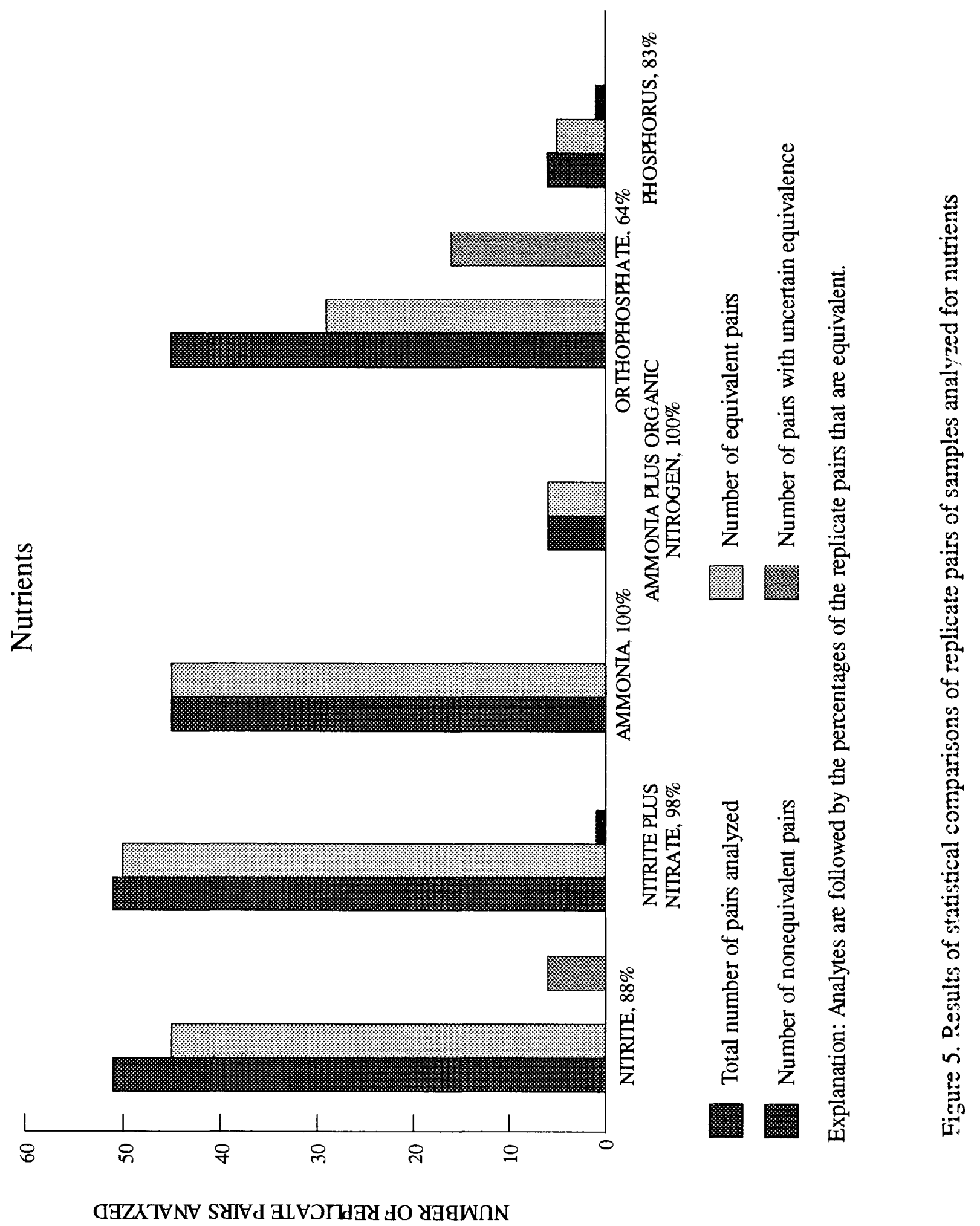




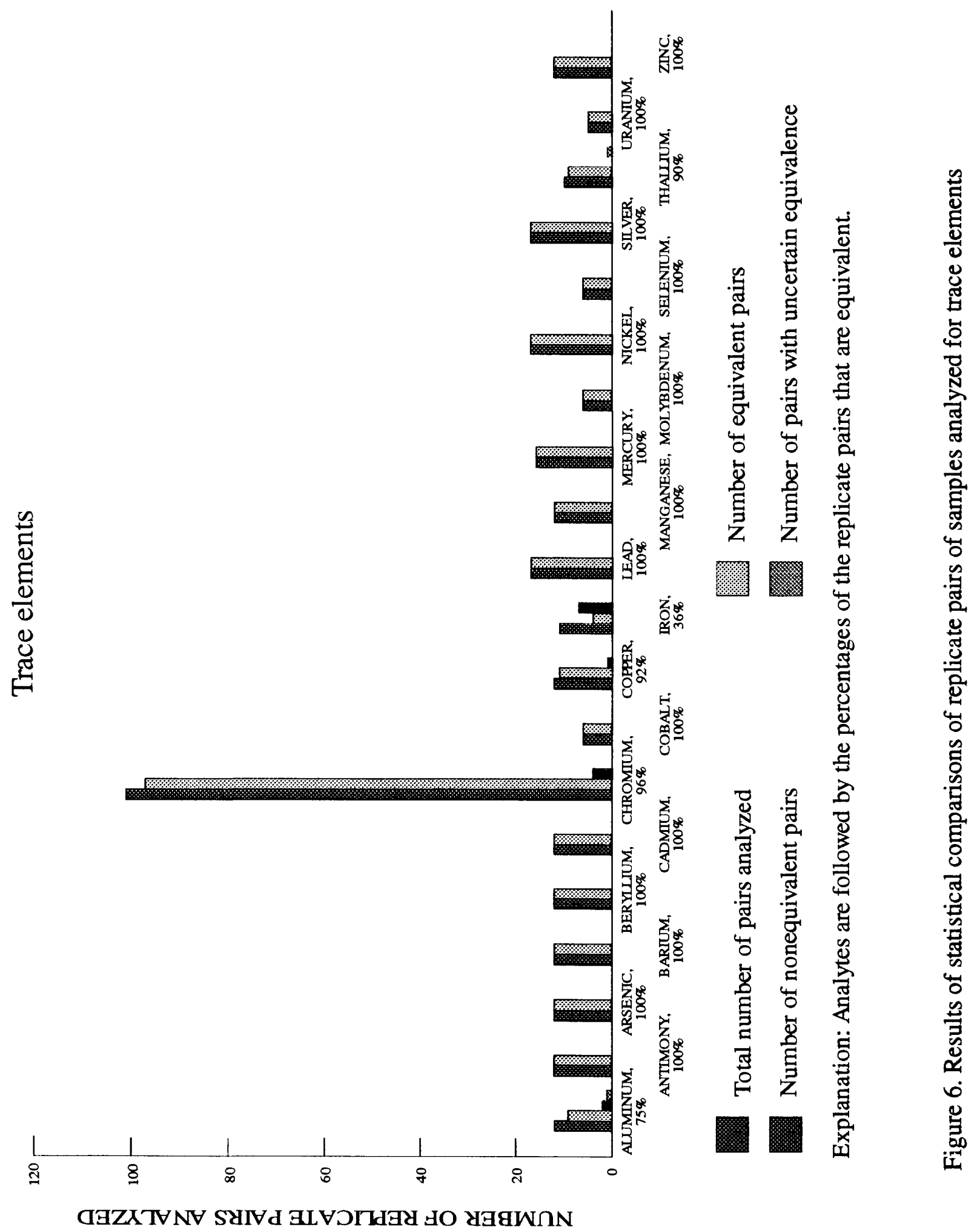




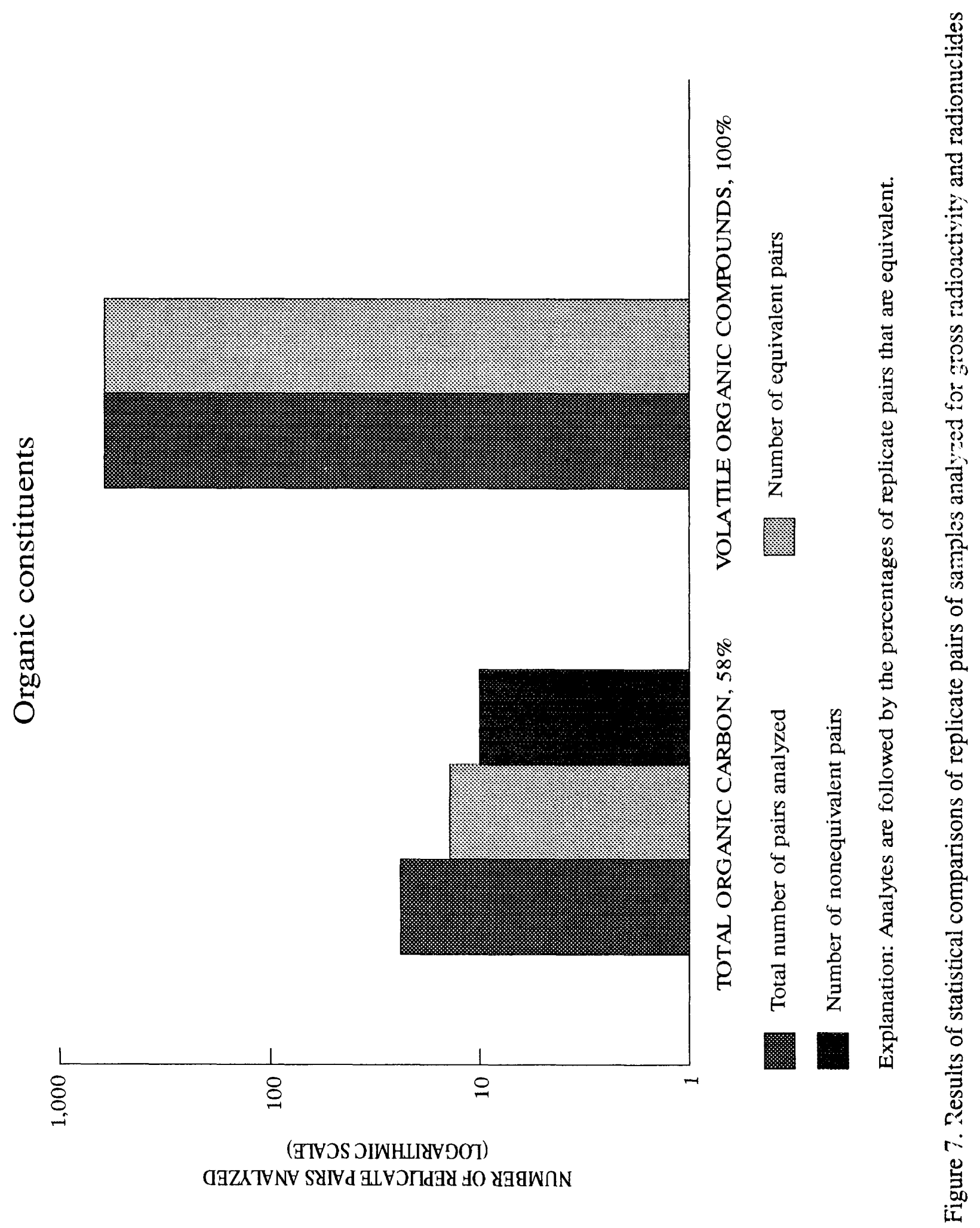




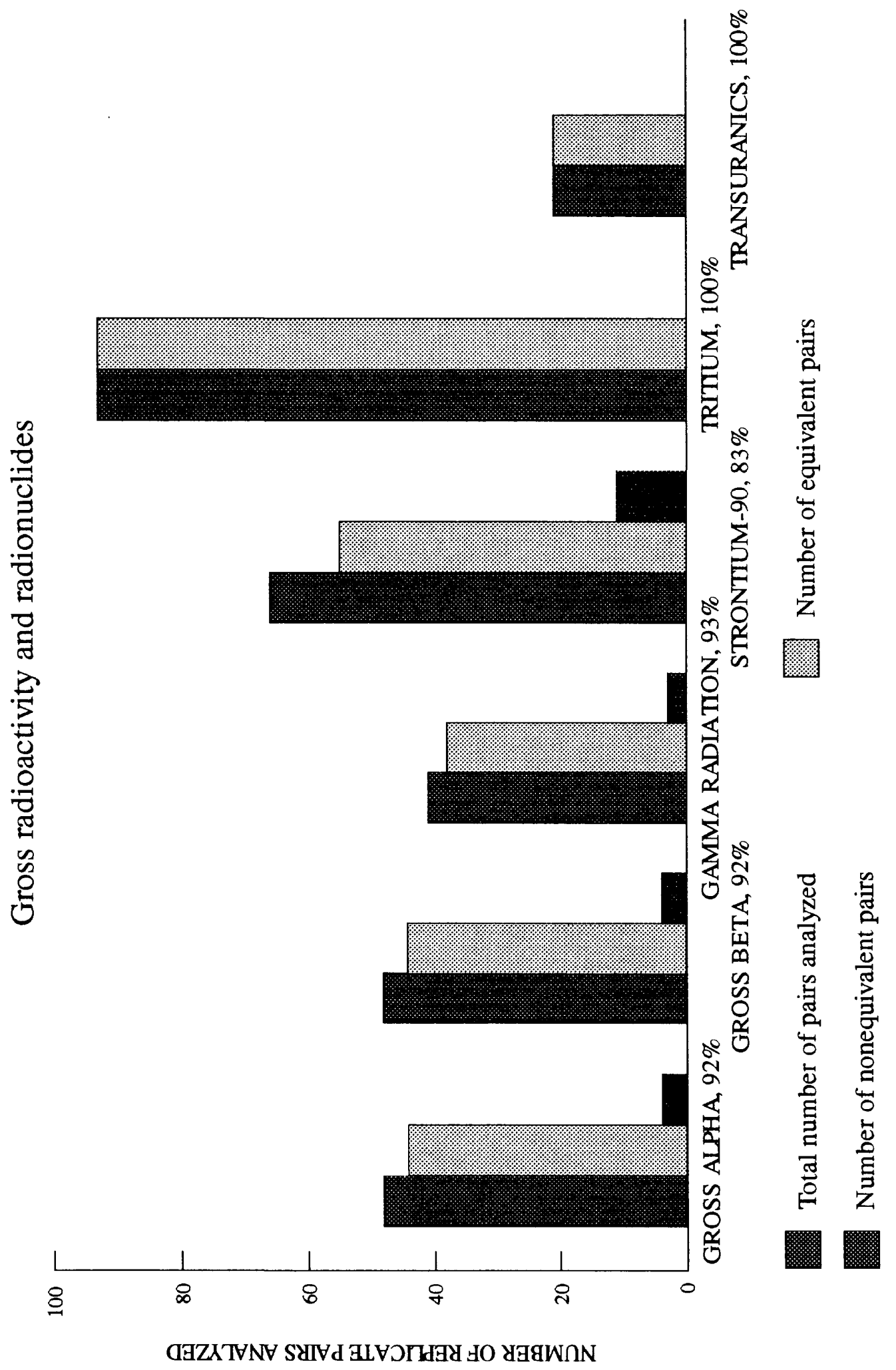

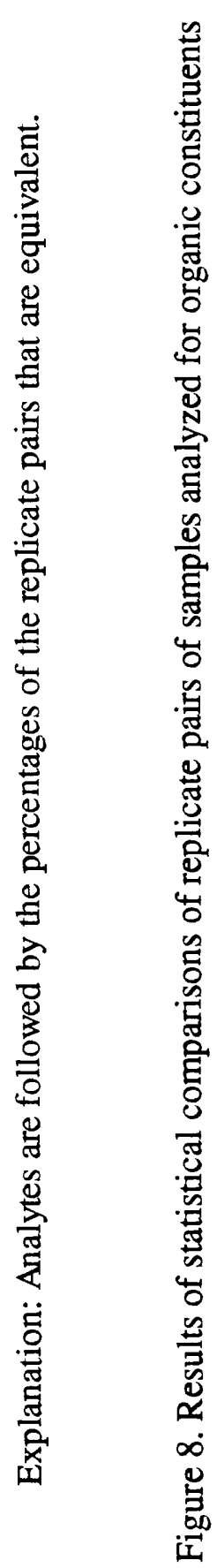


indicated that 6 replicate pairs analyzed for major ions were not equivalent and 211 pairs, or 97 percent of the results, were equivalent.

Nutrients.-Several replicate pairs of samples were analyzed by the NWQL for dissolved and WWR nutrients. The nutrients and the number of replicate pairs follow: dissolved nitrite, 51 ; dissolved nitrite plus nitrate, 51 ; dissolved ammonia, 45; WWR ammonia plus organic nitrogen, 6; dissolved orthophosphate, 45; and WWR phosphorus, 6 .

For all but the nitrite analyses, the $\mathrm{Z}$-values were calculated with the analytical results and the MPD's determined with the regression equations formulated by the BTD\&QS from the SRWS program data. The precision statement for the method of nitrite analysis (Fishman, 1993, p. 147) does not include concentrations at or even twice the reporting level; however, at $0.03 \mathrm{mg} / \mathrm{L}$ the standard deviation is listed as $0.001 \mathrm{mg} / \mathrm{L}$. Although the orthophosphate analysis is included in the BSP, the concentrations are higher than the concentrations of the QA replicate sample pairs collected at the INEL. Equivalence could not be determined for either the replicate pairs analyzed for nitrite or orthophosphate which were below $0.03 \mathrm{mg} / \mathrm{L}$; therefore, it is uncertain whether the results are equivalent and a " $U$ " appears in the column labeled "Remark".

Nutrients analyzed and percentages of the analytical results of the replicate pairs that were equivalent, or that were uncertain follow: nitrite, 88 percent equivalent, 12 percent uncertain; nitrite plus nitrate, 98 percent equivalent; ammonia, 100 percent equivalent; ammonia plus organic nitrogen, 100 percent equivalent; orthophosphate, 64 percent equivalent, 36 percent uncertain; and phosphorus, 83 percent equivalent. The $\mathrm{Z}$-values indicated that 2 replicate pairs analyzed for nutrients were not equivalent, 22 pair were uncertain, and 180 pairs, or 88 percent of the results, were equivalent.

Trace elements.-Several replicate pairs of samples were analyzed by the NWQL for trace elements; the analyses were for the dissolved and/or WWR constituents. The trace element and the number of replicate pairs follow: aluminum, 12; antimony, 12; arsenic, 12; barium, 12; beryllium, 12; cadmium, 12; chromium, 101; cobalt, 6; copper, 12; iron, 11; lead, 17; manganese, 12; mercury, 16; molybdenum, 6; nickel, 17; selenium, 6; silver, 17; thallium, 10; uranium, 5; and zinc, 12. All the $Z$-values were calculated with the analytical results and the MPD's determined with the regression equations formulated by the BTD\&OS from the SRWS program data, except for thallium and uranium. These two analyses were not included in the BSP, but the results of each replicate pair were numerically the same, except for one thallium replicate pair where one result was below the MRL and the other at the MRL.

Statistical comparisons of the aluminum analyses indicated 2 replicate pairs were not equivalent, 1 pair was uncertain, and 9 pair, or 75 percent of the results, were equivalent. Only twelve replic?te pairs were analyzed for aluminum; therefore, additional information from the BSP was used to support the conclusions. The information from the QADATA program that is available through the USGS computer network (Lucey, 1990) shows that the aluminum analyses of the BSP samples hav? displayed high variability with 20 percent of the dissolved aluminum analyses and 12 percent of the WWR aluminum analyses outside the two sigm a control limits. The BTD\&QS has reset the cont ol limits to three sigma and the MPD's used in the statistical comparisons of the replicate pairs have been multiplied by 1.5 to adjust for the increased variability.

Statistical comparisons of the iron analyses indicated that 7 replicate pairs were not equivalent, and 4 pair, or 36 percent of the results, were equivalent. The BTD\&QS has noted significant lack of precision for the same procedure at the NWQL and that the NWQL personnel are aware of the problem (Ludtke, A., 1995; and Ludtke, A. and Woodworth, M., 1995; U.S. Geological Survey, written commun.). The information from the QADATA program also shows that 12 percent of the WWR iron analyses were outside the two sigma control limits. Because the unfiltered samples collected at INEL were for WWR iron, they may not have been representative samples because of inhomogeneity of the water samples or contamination from the well structures. However, the samples analyzed for WWR iron in the BSP were split samples that were also analyzed for dissolved iron; the difference in the analyses was an added digestion procedure (Maloney. and others, 
1993, p. 3). This indicated that the lack of equivalence between replicate pairs analyzed for WWR iron partly resulted from laboratory conditions.

The argument that it may be difficult to compare replicate samples analyzed for a WWR constituent, rather than for the dissolved constituent, is valid. It is possible that sequential ground-water samples may be inhomogeneous because sediment may be present in each sample of a replicate pair in different quantities or different compositions. Therefore, sediment may contribute in varying amounts to the concentration of the WWR constituent, and the results of the replicate pair would not be equivalent statistically.

All of the results of the replicate pairs analyzed for trace elements were equivalent except the following, which are listed with the percentage that were equivalent: aluminum, 75 percent; chromium, 96 percent; copper, 92 percent; iron, 36 percent; and thallium, 90 percent. The $Z$-values indicated that 14 replicate pairs analyzed for trace elements were not equivalent, 2 pairs were uncertain, and 304 pairs, or 95 percent of the results, were equivalent.

\section{Gross radioactivity and radionuclides}

Gross alpha radioactivity.-There were 48 replicate pairs of samples analyzed by NWQL and the RESL for gross alpha radioactivity. The NWQL reported results as gross alpha, dissolved as thorium-230 and as natural uranium. The RESL reported results as gross alpha radioactivity. The Z-values indicated that 4 replicate pairs were not equivalent and 44 pairs, or 92 percent of the results, were equivalent.

Gross beta radioactivity.-There were 48 replicate pairs of samples analyzed by the NWQL and the RESL for gross beta radioactivity. The NWQL reported results as gross beta, dissolved as cesium-137 and as strontium-90/yttrium-90. The

RESL reported results as gross beta radioactivity. The Z-values indicated that 4 replicate pairs were not equivalent and 44 pairs, or 92 percent of the results, were equivalent.

Gamma radiation.-There were 41 replicate pairs of samples analyzed by the RESL for gamma radiation. The $\mathrm{Z}$-values indicated that 3 replicate pairs were not equivalent and 41 pairs, or 93 percent of the results, were equivalent.

Strontium-90.-There were 66 replicate pairs of samples analyzed by the RESL for strontium- 90 . The $\mathrm{Z}$-values indicated that 11 replicate pairs were not equivalent and 55 pairs, or 83 percent of the results, were equivalent.

The reason for the lack of equivalence could not be clearly defined. A report that evaluates field sampling and preservation methods for strontium-90 in ground water at the INEL (Cecil and others, 1989) found no statistical difference between filtered or unfiltered, acidified or unacidified ground water samples. The samples, however, continue to be acidified as they have been in the past as recommended in the report. The samples are labeled at the sampling site to avoid sample mix-up.

Tritium.-There were 93 replicate pairs of samples analyzed for tritium; 5 pairs were analyzed by the NWQL and 86 pairs were analyzed br' the RESL. The NWQL analyzed the routine waterquality sample and the RESL analyzed the QA sample in two additional replicate pairs. The $Z$-values indicated that 100 percent of the results were equivalent.

Transuranics: americium-241, plutonium-238. and plutonium-239/240.-There were seven replicate pairs of samples analyzed by the RESL for each of three transuranic isotopes. The Z-value indicated that 100 percent of the results of the replicate pairs were equivalent for each isotope.

\section{Organic Constituents}

Total organic carbon.-There were 24 replicate pairs of samples analyzed by the NWQL for total organic carbon. For most analyses, an MPD derived from linear regression equations formulated by the BTD\&QS from the SRWS program data, or a reported standard deviation may be used to quantify the precision associated with the analytical results. Neither an MPD nor a standard deviation was available for analysis of total organi? carbon.

The precision data for the dissolved organic carbon method (Wershaw and others, 1987, p. 15) was used to determine a linear regression equation 
for calculating standard deviations at low concentrations because there is no precision data for the total organic carbon method. The precision statement for the total organic carbon method only states that the percent RSD for total organic carbon will be greater than that for dissolved organic carbon (Wershaw and others, 1987, p. 16). When using the analytical results and the standard deviations at low concentrations calculated with the linear regression equation, the $\mathrm{Z}$-values indicated that 10 replicate pairs were not equivalent and 14 pairs, or 58 percent of the results, were equivalent.

The reason for the lack of equivalence of the replicate pairs could not be clearly defined.

Volatile organic compounds.-There were 10 replicate pairs of samples analyzed by the NWQL for 63 volatile organic compounds. Two of the replicate pairs had concentrations of three of the volatile organic compounds that were at or greater than the MRL. Because neither an MPD nor a stan-dard deviation was available for these three volatile organic compounds, the standard deviations were calculated from the RSD's provided by Rose and Schroeder (1995). The compounds and the RSD's used to determine the standard deviations for the statistical comparisons follow: carbon tetrachloride, 8.4 percent; 1,1,1-trichloroethane, 12 percent; and trichloroethene, 13 percent.

All the replicate pairs analyzed for the compounds with concentrations at or above the MRL were equivalent when compared statistically using equation 1. All the results of the replicate pairs that were less than the MRL were considered equivalent. Therefore, 100 percent of the results of replicate pairs analyzed for volatile organic compounds were equivalent.

\section{QUALITY ASSURANCE/QUALITY CONTROL DATA, BLANK SAMPLES}

Blank samples were prepared using deionized water from the Idaho Falls Field Office and inorganic blank water (IBW) and volatile organic compound blank water (VBW) from the NWQL. Several different types of blank samples were prepared: three source-solution, one trip, and four equipment.
A source solution is water that is free of the constituents of interest and is used as a stock solution for other blanks. For example, deionized water may be used to prepare an equipment blant of the filtration apparatus, and the source-solution blank would be a sample of the deionized water hefore it was filtered. Analytical results of a source-solution blank are used to determine the variability of methods or analysts within a labor:tory. They are also used to determine whether the laboratory has introduced a bias into the analytical process. Furthermore, this type of blank is used to determine if, in fact, the source solution is free of the constituents of interest.

A trip blank travels with the samples during collection, storage, and shipment to detect bias related to handling procedures or ambient conditions.

An equipment blank that has been run through all or part of the sampling apparatus can be used to detect a bias that has been introduced through use of that equipment. Also, equipment blanks can b: used to identify contamination from the samplecollection or equipment-cleaning processes. Only deionized water from the Idaho Falls Field Offic? and IBW and VBW from NWQL, which have he? shown to be free of the constituents of interest, are used for rinsing the sampling apparatus and preparing blanks.

Blanks should not have measurable concentrations of the constituents of interest. Measurable concentrations are those that exceed the MRL's plus twice the MPD or standard deviation; radiochemical concentrations should not exceed two standard deviations. When blanks have measurat"e, concentrations of the constituents of interest, they are considered contaminated and corrective actions must be taken. For example, analytical results of source-solution blanks that had been prepared with the distilled and deionized water from the analytical laboratories at the RESL and the Idaho Chemical Processing Plant (ICPP) showed measurable concentrations of several constituents of interest (Williams, 1995). Consequently, water from the RESL and the ICPP is no longer used.

Equipment blanks that have measurable concentrations of the constituents of interest must $b$ ? carefully evaluated to determine the source of contamination. After the possibilities that the 
contamination resulted from a laboratory error or an unsatisfactory source solution are ruled out, it could be concluded that the equipment was inadequately cleaned and additional training must be provided concerning the proper cleaning of sampling equipment. The analytical results of the affect-ed samples must be assessed to see whether there is a detectable bias present that could distort the data.

From 1994 through 1995, sequential QA designations were given to QA/QC samples beginning with QA-1 each sampling session; QAS designations were given to the Naval Reactors Facility QA/QC samples and were numbered sequentially from QAS-34 to QAS-45. Sources and descriptions of source-solution blanks, a trip blank, and equipment blanks that were analyzed by both the NWQL and the RESL for the water-quality monitoring progran are presented in tables 8 through 9. Analytical results of the source-solution blanks, a trip blank, and equipment blanks are presented in tables 49 through 52 .

\section{Source-Solution Blank and Trip Blank Results}

The deionized water from the Idaho Falls Field Office was used for rinsing the measuring and sampling equipment and for preconditioning filters when necessary. It was also used for preparing a trip blank and equipment blanks. Because the Idaho Falls Field Office is located some distance from the INEL Project Office, the deionized water is transported to the INEL in large polyethylene containers and stored until needed. To ensure that the deionized water is free of the constituents of interest, two source-solution blanks were prepared.

One source-solution blank, QA-2, was analyzed for chloride, dissolved chromium, and hexavalent chromium. This blank, and another sourcesolution blank, QA-3, were analyzed for gamma radiation, strontium-90, and tritium. No measurable concentrations of the constituents of interest were found.

At the beginning of the January 1995 sampling session, a trip blank, QA-318, and a sourcesolution blank, QA-317, were prepared with the deionized water from the Idaho Falls Field Office. The source-solution blank was sent to the NWQL for analyses, and the trip blank travelled throughout the sampling session in the field laborstory as the field personnel collected and prepared the routine water-quality samples. At the end of the sampling session, the trip blank was sent to the NWQL along with the last of the samples. The source-solution blank, QA-317, and trip blank, QA-318, were analyzed for sodium, chloride, dissolved chromium, hexavalent chromium, nutrients and volatile organic compounds ${ }^{1}$. No measurable concentrations of those constituents were found.

\section{Equipment-Blank Results}

Three source solutions have been used for equipment blanks: deionized water from the Idahe Falls Field Office and IBW and VBW from the NWQL. The equipment-blank source solutions were passed through and collected from different sampling apparatus in the same manner as the routine water-quality samples. Then, the blanks were analyzed for the constituents of interest to determine if the sampling process had introduced a bias to the analytical results.

Three equipment blanks, QA-3, QA-5, and QA-8, were analyzed for chloride, dissolved chromium, hexavalent chromium, strontium-90, and tritium. Additionally, QA-5, was analyzed for sodium and gamma radiation; and QA-8, for sulfate. Those three equipment blanks had no measurable concentrations of the constituents of interest.

One equipment blank, QAS-39, was prepared with two source solutions; samples for analyses of major ions, nutrients, trace elements, tritium, gros? alpha and gross beta radioactivity were prepared with IBW; for total organic carbon, VBW. Measurable concentrations of tritium, gross alpha and gross beta radioactivity, and total organic carbon were found. It is unlikely that the source solutions provided by the NWQL were contaminated with those constituents. The measurable concentrations of those constituents may have been due to bias $0^{*}$ error in the sample analyses or may be due 10 inadequate cleaning of the equipment. The data

\footnotetext{
${ }^{1}$ Because all of the analytical results for volatile organic compounds were less than the minimum reporting level, they were not tabulated.
} 
Table 8. Identification, source, and description of source-solution blanks and a trip blank for the water-quali?", monitoring program at the Idaho National Engineering Laboratory

[Site identifier: see Quality Assurance/Quality Control Data, Blank Samples section or explanation]

\begin{tabular}{lccc}
\hline \multicolumn{1}{c}{ Site identifier } & Date prepared & Source & Description \\
\hline & & Source-solution blanks & \\
QA-2 & $7 / 15 / 94$ & U.S. Geological Survey, & Deionized water \\
QA-317 & $1 / 9 / 95$ & Idaho Falls Field Office & \\
QA-3 & $2 / 8 / 95$ & & \\
& & Trip blank & Deionized water \\
& $2 / 1 / 95$ & U.S. Geological Survey, & \\
QA-318 & Idaho Falls Field Office & \\
\end{tabular}

Table 9. Identification, source, and description of equipment blanks for the water-quality monitoring progran at the Idaho National Engineering Laboratory

[Site identifier: see section on Quality Assurance/Quality Control Data, Blank Samples for explanation. Abbreviation: IBW, inorgan; blank water; VBW, volatile organic compound blank water]

\begin{tabular}{|c|c|c|c|}
\hline Site identifier & Date prepared & Source & Description \\
\hline $\begin{array}{l}\text { QA-5 } \\
\text { QAS-391 } \\
\text { QA-8 }\end{array}$ & $\begin{array}{c}7 / 28 / 94 \\
11 / 10 / 94 \\
7 / 17 / 95\end{array}$ & $\begin{array}{l}\text { IBW from the National Water Quality } \\
\text { Laboratory }\end{array}$ & $\begin{array}{l}\text { Rinsate of sampling equipment } \\
\text { and filtering apparatus }\end{array}$ \\
\hline QA-3 & $7 / 15 / 94$ & $\begin{array}{l}\text { Deionized water from the } \\
\text { U.S. Geological Survey, } \\
\text { Idaho Falls Field Office }\end{array}$ & $\begin{array}{l}\text { Rinsate of sampling equipment } \\
\text { and filtering apparatus }\end{array}$ \\
\hline QAS-39 1 & $11 / 10 / 94$ & $\begin{array}{l}\text { VBW from the National Water Quality } \\
\text { Laboratory }\end{array}$ & Rinsate of filtering apparatus \\
\hline
\end{tabular}

${ }^{1}$ The equipment blank was prepared with two source solutions.

from the last routine water-quality samples that were collected were carefully assessed to determine if there was a detectable bias. All the data were within range of the historical data and no bias could be determined.

\section{SUMMARY AND CONCLUSIONS}

More than 4,000 water samples were collected by the USGS from 179 monitoring sites for the water-quality monitoring program at the INEL from 1994 through 1995. Approximately 500 of the water samples were replicate or blank samples collected for the quality assurance/quality control program. Analyses were performed by the NWQL and the RESL to determine the concentrations of major ions, nutrients, trace elements, gross radio. activity and radionuclides, total organic carbon, and volatile organic compounds in those samples. The precision of field and laboratory methods can be assessed with the data from the analyses of th? replicate pairs of samples. Although many factors may affect precision, the determination of the equivalence of replicate pairs of samples, along with the BTD\&QS report concerning the NWQL (Maloney and others, 1993) and historical data, is useful in assessing sources of imprecision, bias, and, in some cases, inaccuracy. 
To evaluate the precision of field and laboratory methods, analytical results of the replicate pairs of samples were compared statistically for equivalence on the basis of the precision associated with each result. Within the major ion analyses, 97 percent were equivalent; nutrients, 88 percent; trace elements, 95 percent; gross radioactivity and radionuclides, 93 percent; and organic constituents, 98 percent. In all, the statistical comparison of the data indicated that 95 percent of the replicate pairs were equivalent. The large percentage of analytical results of replicate pairs that were equivalent indicates that the samples were being collected in a manner that ensures the quality of the data.

Ninety percent or more of the analytical results of replicate pairs were equivalent for each constituent when tested statistically except for the following: (which are listed with the percentages that were equivalent) nitrite, 88 percent; orthophosphate, 64 percent; phosphorus, 83 percent; aluminum, 75 percent; iron, 36 percent; strontium-90, 83 percent; and total organic carbon, 58 percent.

The precision statement for the method of nitrite analysis (Fishman 1993, p. 147) does not include concentrations at or twice the reporting level; however, at $0.03 \mathrm{mg} / \mathrm{L}$ the standard deviation is listed as $0.001 \mathrm{mg} / \mathrm{L}$. Although, the orthophosphate analysis is included in the BSP, the concentrations are higher than the concentrations of the QA replicate sample pairs collected at the INEL. Therefore, equivalence of the replicate pairs analyzed for nitrite and orthophosphate that were below $0.03 \mathrm{mg} / \mathrm{L}$ was uncertain.

Lack of precision for analytical methods to determine the concentrations of aluminum and iron has been documented by the BTD\&QS in the BSP. The information from the QADATA program that is available through the USGS computer network (Lucey, 1990) shows that 20 percent of the dissolved aluminum analyses and 12 percent of the WWR aluminum analyses were outside the two sigma control limits. The BTD\&QS also has noted significant lack of precision for the WWR iron analyses at the NWQL (Ludtke, A., 1995; Ludtke A. and Woodworth, M., 1995, USGS, written communs.). The QADATA program shows that 14 percent of those analyses also were outside the two sigma control limits. Although the unfiltered samples collected at INEL were for WWR iron and they may not have been representative samples owing to inhomogeneity of the water samples or contamination from the well structures, information from the BTD\&QS shows that the lacl of equivalence between replicate pairs partly resulted from laboratory conditions.

The reason for the lack of equivalence between the replicate pairs analyzed for strontium-90 could not be clearly defined. A report that evaluates field sampling and preservation methods for strontium-90 in ground water at the INEL (Cecil and others, 1989) found no statistical difference between filtered or unfiltered, acidified or unacidified ground water samples. The samples, however, continue to be acidified as they have been in the past as recommended in the report. The samples are labeled at the sampling site to avoid sample mix-up.

Neither an MPD nor a standard deviation was available for analysis of total organic carbon. Therefore, precision data for the dissolved organic carbon method (Wershaw and others, 1987, p. 15) was used to determine a linear regression equation for the calculating standard deviations at low concentrations. When using the analytical results and the standard deviations at low concentrations calculated with the linear regression equation, the Z-values indicated that 11 replicate pairs were not equivalent and 13 pairs, or 54 percent of the results, were equivalent. The reason for the lack of equivalence of the replicate pairs could not be clearly defined.

Blanks are an important component of the QA/QC program. Source solutions were used for preparation of blanks were deionized water from the Idaho Falls Field Office and IBW and VBW from the NWQL. Analytical results of a sourcesolution blank are used to determine variability or bias at the laboratory. Furthermore, this type of blank is used to determine if, in fact, the blank solution is free of the constituents of interest. A trip blank travels with the samples during collection, storage, and shipment to detect bias related to handling procedures or ambient conditions. An equipment blank that has been passed through and collected from all or part of the sampling apparatus may be used to detect bias that may been 
introduced through use of that equipment. Blanks should not have measurable concentrations of the constituents of interest. Measurable concentrations are those that exceed the MRL's plus twice the MPD or standard deviation. The radiochemical concentrations of blanks should not exceed two standard deviations.

Three source-solution blanks, one trip blank, and four equipment blanks were prepared and analyzed. The blanks had no measurable concentrations of the constituents of interest, except for one equipment blank, QAS-39, which had measurable concentrations of total organic carbon, tritium, and gross alpha and gross beta radioactivity. It is unlikely that the source solutions provided by the NWQL were contaminated with those constituents, and the measurable concentrations of those constituents were probably due to bias or error in the sample analyses or inadequate cleaning of equipment. The data from the last routine water-quality samples that were collected were carefully assessed to determine if there was a detectable bias. All the data were within range of the historical data and no bias could be determined.

Evaluation of the QA/QC data, the information from the BSP, and historical data help to assess precision and bias of field methods used by the personnel at the INEL Project Office. The large percentage of replicate pairs of samples that are equivalent and of blank results that are free of the constituents of interest validates the methods and procedures and supports the reliability of the data. Furthermore, the QA/QC data are useful in determining the source of inconsistencies when lack of equivalence between replicate pairs or blanks with measurable concentrations of the constituents of interest are detected. For example, when results of a specific analysis for several replicate pairs are not equivalent, and the results for other analyses of those pairs are equivalent, the source of the inconsistencies may be the laboratory procedures. On the other hand, when results of all the analyses for a replicate pair are not equivalent, the source of the inconsistencies may be the field procedures. In general, replicate samples do not address accuracy; but, a large Z-value, when the results of two replicate samples are tested statistically for equivalence, suggests that at least one of the samples is inaccurate.

\section{REFERENCES CITED}

Bodnar, L.Z., and Percival, D.R., eds., 1982, Analytical Chemistry Branch Procedures Manual-Radiological and Environmental Sciences Laboratory: U.S. Department of Energy Report IDO-12096, variable pagination.

Cecil, L.D., Knobel, L.L., Wegner, S.J., and Moore, L.M., 1989, Evaluation of field sampling and preservation methods for strontium-90 in ground water at the Idaho National Engineering Laboratory, Idaho: U.S. Geological Survey Open-File Report 89-4146, $24 \mathrm{p}$.

Erdmann, D.E., and Thomas, J.D., 1985, Quality assurance of U.S. Geological Survey waterquality field measurements, in Taylor, J.K., and Stanley, T.W., eds., Quality assurance for environmental measurements: Philadelphia, American Society for Testing and Materials, ASTM STP 867, 441 p.

Fishman, M.J., ed., 1993, Methods of analysis by the U.S. Geological Survey National Water Quality Laboratory-Determination of inorganic and organic constituents in water ar'l fluvial sediments: U.S. Geological Survey Open-File Report 93-125, 217 p.

Hardy, M.A., Leahy, P.P., and Alley, W.M., 1989, Well installation and documentation, and ground-water sampling protocols for the pilot National Water-Quality Assessment Program: U.S. Geological Survey Open-File Report 89-396, 36 p.

Horowitz, A.J., Demas, C.R., Fitzgerald, K.K., Miller, T.L., and Rickert, D.A., 1995, U.S. Geological Survey protocol for the collection and processing of surface-water samples for the subsequent determination of inorganic constituents in filtered water: U.S. Geological Survey Open-File Report 94-539, 57 p.

Long, H.K., and Farrar, J.W., 1993, Report of the U.S. Geological Survey's evaluation program for standard reference samples distributed in April 1993 T-123 (trace constituents), T-125 
(trace constituents), M-126 (major constituents), N-38 (nutrients), N-39 (nutrients), P-20) (low ionic strength), and $\mathrm{Hg}-16$ (mercury): U.S. Geological Survey Open-File Report 93-436, $149 \mathrm{p}$.

Lucey, K.J., 1990, QADATA User's Manual: An interactive computer program for the retrieval and analysis of the results from the external blind sample quality-assurance project of the U.S. Geological Survey: U.S. Geological Survey Open-File Report 90-162, 53 p.

Maloney, T.J., Ludtke, A.S., and Krizman, T.L., 1993, Quality assurance for routine water analysis in the laboratories of the U.S. Geological Survey for water year 1990: U.S. Geological Survey Water-Resources Investigations Report 93-4082, 145 p.

Olson, D.G. and Percival, D.R., 1980, Collecting, Pretreating, Packaging, and Shipping Samples to the Radiological and Environmental Sciences Laboratory in Bodnar, L.Z., and Percival, D.R., eds., 1982, Analytical Chemistry Branch Procedures Manual-Radiological and Environmental Sciences Laboratory: U.S. Department of Energy Report IDO-12096, variable pagination.

Ott, R.L., 1993, An introduction to statistical methods and data analysis (4th ed.): Belmont, California, Wadsworth Publishing Company, $1183 \mathrm{p}$.

Pritt, J., and Jones, B.E., eds., 1989, 1990 National Water Quality Laboratory Services Catalog: U:S. Geological Survey Open-File Report 89-386, variable pagination.

Pritt, J.W. and Raese, J.W., eds., 1992, Quality Assurance/Quality Control Manual, National Water Quality Laboratory, U.S. Geological Survey Open-File Report 92-495, 33 p.

Rose, D.L., and Schroeder, M.P., 1995, Methods of analysis by the U.S. Geological Survey National Water Quality Laboratory-Determination of volatile organic compounds in water by purge and trap capillary gas chromatograph/mass spectrometry: U.S. Geological Survey Open-File Report 94-708, 26 p.
Timme, P.J., 1994, 1994 National Water Quality Laboratory Services Catalog: U.S. Geological Survey Open-File Report 94-304, variable pagination.

Timme, P.J., 1995, 1995 National Water Quality Laboratory Services Catalog: U.S. Geological Survey Open-File Report 95-352, variable pagination.

Volk, William, 1969, Applied statistics for engineers ( $2 \mathrm{~d}$ ed.): New York, McGraw-Hill Book Company, 415 p.

Wershaw, R.L., Fishman, M.J., Grabbe, R.R., and Lowe, L.L, eds., 1987, Methods for the determination of organic substances in water and fluvial sediments: Techniques of WaterResources Investigations of the U.S. Geological Survey, book 5, chap. A3, p.

Williams, L.M., 1995, Evaluation of Quality Assurance/Quality Control Data Collected by the U.S. Geological Survey for Water-Quality Activities at the Idaho National Enginecring Laboratory, Idaho, 1989 through 1993: U.S. Geological Survey Investigations Report 96-4148, $116 \mathrm{p}$.

Wood, W.W., 1981, Guidelines for collection and field analysis of ground-water samples for selected unstable constituents: U.S. Geological Survey Techniques of Water-Resources Investigations, book 1, chap. D2, 24 p. 
SUPPLEMENTAL INFORMATION SECTION 
Table 10. Comparison of results of replicate pairs of samples from the Idaho National Engineering Laborationy analyzed for sodium-Continued

[Analyses by the National Water Quality Laboratory. Site identifier: see figures $1-3$ for location of sites. Z-value: see section on statistical comparisons for explanation. Remark: no entry, analytical results of replicate pairs are statistically equivalent; $N$, analy ${ }^{*} i c a l$ results of replicate pairs are not statistically oquivalent. Abbreviations: $Q A$, quality-assurance replicate sample; $\mathrm{mg} / \mathrm{L}$, milligram $p$ ? liter. Symbol: *, the QA sample was collected within 24 hours of the routine water-quality sample, rather than sequentially]

\begin{tabular}{|c|c|c|c|c|c|}
\hline Site identifier & Date sampled & $\begin{array}{l}\text { Sodium } \\
\text { (mg/L) }\end{array}$ & $\begin{array}{l}\text { Sodium, QA } \\
\quad(\mathrm{mg} / \mathrm{L})\end{array}$ & Z-value & Remark \\
\hline \multicolumn{6}{|c|}{ Dissolved } \\
\hline ANP-9 & $10 / 14 / 94$ & 14 & 15 & 0.92 & \\
\hline ARBOR Test & 9/29/94 & 16 & 16 & .00 & \\
\hline \multirow[t]{3}{*}{ CFA 1} & $4 / 7 / 94$ & 29 & 30 & .52 & \\
\hline & $1 / 5 / 95$ & 19 & 18 & .76 & \\
\hline & $4 / 13 / 95$ & 29 & *30 & .52 & \\
\hline \multirow[t]{2}{*}{ CFA LF 2-10 } & $11 / 10 / 94$ & 10 & 10 & .00 & \\
\hline & $10 / 25 / 95$ & 13 & 13 & .00 & \\
\hline Hwy 3 & $10 / 12 / 94$ & 5.9 & $* 5.7$ & .34 & \\
\hline MTR Test & $4 / 26 / 95$ & 26 & 26 & .00 & \\
\hline NPR Test & $4 / 14 / 94$ & 8.1 & 8 & .14 & \\
\hline PSTF & $4 / 10 / 95$ & 6.9 & 6.7 & .31 & \\
\hline PW-5 & $10 / 20 / 94$ & 160 & 160 & .00 & \\
\hline Site 17 & $10 / 19 / 94$ & 9.7 & 10 & .36 & \\
\hline Tan Expl. & $4 / 12 / 94$ & 9.6 & 10 & .49 & \\
\hline TRA A-13 & $10 / 4 / 95$ & 22 & 23 & .65 & \\
\hline USGS 2 & $7 / 13 / 95$ & 16 & 16 & .00 & \\
\hline USGS 4 & $4 / 19 / 95$ & 48 & 48 & .00 & \\
\hline USGS 6 & 7/19/94 & 13 & 14 & .97 & \\
\hline USGS 7 & $4 / 6 / 95$ & 23 & 23 & .00 & \\
\hline USGS 11 & $10 / 26 / 95$ & 9.1 & 9.2 & .14 & \\
\hline USGS 17 & $10 / 28 / 94$ & 7.0 & *7.1 & .15 & \\
\hline USGS 18 & $7 \pi / 95$ & 12 & 12 & .00 & \\
\hline USGS 23 & $10 / 10 / 95$ & 10 & 9.8 & .24 & \\
\hline USGS 26 & $4 / 11 / 95$ & 15 & 15 & .00 & \\
\hline USGS 29 & $10 / 11 / 94$ & 20 & 20 & .00 & \\
\hline USGS 31 & $4 / 1 / 94$ & 16 & 16 & .00 & \\
\hline USGS 42 & $10 / 18 / 94$ & 11 & 9.9 & 1.28 & \\
\hline USGS 44 & $10 / 16 / 95$ & 8.8 & 9.1 & .39 & \\
\hline USGS 45 & $10 / 11 / 95$ & 11 & 12 & 1.09 & \\
\hline USGS 47 & $10 / 16 / 95$ & 17 & 17 & .00 & \\
\hline USGS 53 & $10 / 25 / 94$ & 13 & 13 & .00 & \\
\hline \multirow[t]{2}{*}{ USGS 55} & $10 / 25 / 94$ & 24 & 24 & .00 & \\
\hline & $10 / 4 / 95$ & 22 & 22 & .00 & \\
\hline USGS 59 & 10/23/95 & 65 & 64 & .26 & \\
\hline
\end{tabular}


Table 10. Comparison of results of replicate pairs of samples from the Idaho National Engineering Laboratory analyzed for sodium-Continued

\begin{tabular}{|c|c|c|c|c|c|}
\hline Site identifier & Date sampled & $\begin{array}{c}\text { Sodium } \\
(\mathrm{mg} / \mathrm{L})\end{array}$ & $\begin{array}{l}\text { Sodium, QA } \\
\quad(\mathrm{mg} / \mathrm{L})\end{array}$ & Z-value & Remark \\
\hline \multicolumn{6}{|c|}{ Dissolved-cont. } \\
\hline USGS 67 & $10 / 17 / 95$ & 46 & 47 & 0.34 & \\
\hline \multirow[t]{2}{*}{ USGS 69} & $7 / 11 / 94$ & 11 & 10 & 1.16 & \\
\hline & $7 / 6 / 95$ & 11 & $* 9.9$ & 1.28 & \\
\hline USGS 70 & $10 / 24 / 94$ & 14 & 14 & .00 & \\
\hline USGS 78 & $7 / 13 / 95$ & 7.1 & 7.7 & .87 & \\
\hline USGS 84 & $10 / 18 / 95$ & 8.4 & $* 7.9$ & .69 & \\
\hline USGS 100 & $10 / 19 / 95$ & 17 & 17 & .00 & \\
\hline USGS 101 & $4 / 11 / 94$ & 13 & 9.2 & 4.21 & $\mathrm{~N}$ \\
\hline USGS 105 & $3 / 31 / 94$ & 13 & 14 & .97 & \\
\hline USGS 108 & $4 / 18 / 95$ & 11 & 11 & .00 & \\
\hline USGS 112 & $10 / 13 / 94$ & 69 & 73 & .93 & \\
\hline USGS 116 & $10 / 17 / 95$ & 32 & *33 & .47 & \\
\hline USGS 119 & $10 / 25 / 95$ & 11 & 11 & .00 & \\
\hline USGS 120 & $10 / 23 / 95$ & 26 & 25 & .61 & \\
\hline USGS 121 & $10 / 24 / 94$ & 7.3 & 7.3 & .00 & \\
\hline \multirow[t]{2}{*}{ USGS 123} & $10 / 1 / 94$ & 46 & 46 & .00 & \\
\hline & $10 / 30 / 95$ & 47 & 47 & .00 & \\
\hline USGS 124 & $4 / 21 / 94$ & 9.2 & 14 & 5.13 & $\mathrm{~N}$ \\
\hline USGS 125 & $6 / 16 / 95$ & 12 & 12 & .00 & \\
\hline \multicolumn{6}{|c|}{ Whole water recoverable } \\
\hline NRF-1 & $3 / 10 / 94$ & 15 & 14 & .92 & \\
\hline NRF-2 & $11 / 7 / 95$ & 20 & 20 & .00 & \\
\hline NRF-3 & $6 / 08 / 95$ & 17 & 17 & .00 & \\
\hline NRF-6 & $3 / 10 / 95$ & 73 & 110 & 6.67 & $\mathrm{~N}$ \\
\hline NRF-7 & $6 / 13 / 94$ & 8.3 & 8.2 & .14 & \\
\hline WSINEL1 & 6/9/94 & 14 & 15 & .92 & \\
\hline USGS 15 & $11 / 7 / 94$ & 7.6 & 7.4 & .29 & \\
\hline USGS 17 & $11 / 7 / 95$ & 6.3 & 6.7 & .63 & \\
\hline USGS 98 & $6 / 12 / 95$ & 11 & 9.9 & .00 & \\
\hline USGS 99 & $9 / / 94$ & 13 & 13 & .00 & \\
\hline USGS 102 & $9 / 13 / 95$ & 15 & 14 & .92 & \\
\hline
\end{tabular}


Table 11. Comparison of results of replicate pairs of samples from the Idaho National Engineering Laboratory analyzed for sulfate

(Analyses by the National Water Quality Laboratory. Site identifier: see figures 1-3 for location of sites. Z-value: see section on statistical comparisons for explanation. Remark: no entry, analytical results of replicate pairs are statistically equivalent. Abbreviations: QA, quality-assurance replicate sample; $\mathrm{mg} / \mathrm{L}$, milligram per liter. Symbol: ${ }^{*}$, the QA sample was collected within 24 hours of the routine water-quality sample, rather than sequentially]

\begin{tabular}{|c|c|c|c|c|c|}
\hline Site identifier & Date sampled & $\begin{array}{l}\text { Dissolved } \\
\text { sulfate } \\
\text { (mg/L) }\end{array}$ & $\begin{array}{c}\text { Dissolved } \\
\text { sulfate, QA } \\
(\mathrm{mg} / \mathrm{L})\end{array}$ & Z-value & Remark \\
\hline CFA 1 & $4 / 13 / 95$ & 34 & *35 & 0.26 & \\
\hline CFA LF 2-10 & $10 / 25 / 95$ & 28 & 28 & .00 & \\
\hline NRF-1 & $3 / 10 / 94$ & 39 & 39 & .00 & \\
\hline NRF-2 & $11 / 7 / 95$ & 46 & 46 & .00 & \\
\hline NRF-3 & $6 / 8 / 95$ & 39 & 40 & .25 & \\
\hline NRF-6 & $3 / 10 / 95$ & 270 & 270 & .00 & \\
\hline NRF-7 & $6 / 13 / 94$ & 14 & 14 & .00 & \\
\hline PW-9 & $7 / 11 / 95$ & 78 & 79 & .16 & \\
\hline TRA A-13 & $10 / 4 / 95$ & 270 & 270 & .00 & \\
\hline WSINEL1 & $6 / 9 / 94$ & 42 & 42 & .00 & \\
\hline USGS 2 & $7 / 13 / 95$ & 13 & 13 & .00 & \\
\hline USGS 15 & $11 / 7 / 94$ & 17 & 17 & .00 & \\
\hline USGS 17 & $11 / 7 / 95$ & 18 & 18 & .00 & \\
\hline USGS 18 & $7 / 7 / 95$ & 23 & 23 & .00 & \\
\hline USGS 44 & $10 / 16 / 95$ & 24 & 24 & .00 & \\
\hline USGS 45 & $10 / 11 / 95$ & 24 & 24 & .00 & \\
\hline USGS 47 & $10 / 16 / 95$ & 29 & 29 & .00 & \\
\hline USGS 55 & $10 / 4 / 95$ & 35 & 35 & .00 & \\
\hline USGS 59 & $10 / 23 / 95$ & 28 & 28 & .00 & \\
\hline USGS 67 & $10 / 17 / 95$ & 31 & 30 & .28 & \\
\hline USGS 69 & $7 / 6 / 95$ & 96 & $* 99$ & .42 & \\
\hline USGS 78 & $7 / 13 / 95$ & 18 & 18 & .00 & \\
\hline USGS 84 & $10 / 18 / 95$ & 26 & $* 26$ & .00 & \\
\hline USGS 98 & $6 / 12 / 95$ & 20 & 21 & .33 & \\
\hline USGS 99 & $9 / 7 / 94$ & 26 & 26 & .00 & \\
\hline USGS 100 & 10/19/95 & 11 & 11 & .00 & \\
\hline USGS 102 & 9/13/95 & 34 & 34 & .00 & \\
\hline USGS 116 & $10 / 17 / 95$ & 34 & *34 & .00 & \\
\hline USGS 120 & $10 / 25 / 95$ & 36 & 36 & .00 & \\
\hline USGS 121 & $10 / 24 / 94$ & 23 & 23 & .00 & \\
\hline USGS 123 & $10 / 30 / 95$ & 29 & 29 & .00 & \\
\hline
\end{tabular}


Table 12. Comparison of results of replicate pairs of samples from the Idaho National Engineering Labora'nry analyzed for chloride-Continued

[Analyses by the National Water Quality Laboratory. Site identifier: see figures 1-3 for location of sites. Z-value: see section on statistical comparisons for explanation. Remark: no entry, analytical results of replicate pairs are statistically equivalent; $N$, analytical results of replicate pairs are not statistically equivalent. Abbreviations: QA, quality-assurance replicate sample; $\mathrm{mg} / \mathrm{L}$, milligram per liter. Symbol: *, the QA sample was collected within 24 hours of the routine water-quality sample, rather than sequentially]

\begin{tabular}{|c|c|c|c|c|c|}
\hline Site identifier & Date sampled & $\begin{array}{c}\text { Dissolved } \\
\text { chloride } \\
(\mathrm{mg} / \mathrm{L})\end{array}$ & $\begin{array}{c}\text { Dissolved } \\
\text { chloride, QA } \\
(\mathrm{mg} / \mathrm{L})\end{array}$ & $Z$-value & Remark \\
\hline ANP-9 & $10 / 14 / 94$ & 12 & 12 & 0.00 & \\
\hline ARBOR Test & $9 / 29 / 94$ & 15 & 14 & .74 & \\
\hline Atomic City & $4 / 6 / 94$ & 18 & 18 & .00 & \\
\hline \multirow[t]{3}{*}{ CFA 1} & $4 / 7 / 94$ & 100 & 100 & .00 & \\
\hline & $1 / 5 / 95$ & 67 & 68 & .24 & \\
\hline & $4 / 13 / 95$ & 110 & $* 100$ & 1.61 & \\
\hline \multirow[t]{2}{*}{ CFA LF 2-10 } & $11 / 10 / 94$ & 32 & 33 & .43 & \\
\hline & $10 / 25 / 95$ & 30 & 30 & .00 & \\
\hline CFA LF 3-9 & $7 / 18 / 95$ & 110 & 110 & .00 & \\
\hline Hwy 3 & $10 / 12 / 94$ & 6.2 & $* 6.3$ & .11 & \\
\hline Leo Rogers & $7 / 18 / 94$ & 18 & 19 & .64 & \\
\hline MTR Test & $4 / 26 / 95$ & 26 & 26 & .00 & \\
\hline NPR Test & $4 / 14 / 94$ & 16 & 16 & .00 & \\
\hline NRF-1 & $3 / 10 / 94$ & 37 & 38 & .39 & \\
\hline NRF-2 & $11 / 7 / 95$ & 51 & 50 & .30 & \\
\hline NRF-3 & $6 / 8 / 95$ & 40 & 39 & .37 & \\
\hline NRF-6 & $3 / 10 / 95$ & 250 & 250 & .00 & \\
\hline NRF-7 & $6 / 13 / 94$ & 4.9 & 4.9 & .00 & \\
\hline PSTF & $4 / 10 / 95$ & 6.9 & 6.2 & .76 & \\
\hline PW-4 & $1 / 14 / 95$ & 280 & $* 270$ & .65 & \\
\hline PW-5 & $10 / 20 / 94$ & 240 & 250 & .73 & \\
\hline PW-6 & $1 / 24 / 94$ & 220 & 220 & .00 & \\
\hline PW-9 & $7 / 11 / 95$ & 23 & 22 & .56 & \\
\hline Site 4 & $4 / 13 / 95$ & 12 & 12 & .00 & \\
\hline Site 17 & $10 / 19 / 94$ & 9.9 & 11 & .98 & \\
\hline Tan Expl. & $4 / 12 / 94$ & 18 & 19 & .64 & \\
\hline TRA A-13 & $10 / 4 / 95$ & 33 & 33 & .00 & \\
\hline WSINEL1 & $6 / 9 / 94$ & 74 & 70 & .95 & \\
\hline USGS 2 & $7 / 13 / 95$ & 16 & 16 & .00 & \\
\hline USGS 4 & $4 / 19 / 95$ & 36 & 36 & .00 & \\
\hline USGS 6 & $7 / 19 / 94$ & 8.2 & 8.3 & .10 & \\
\hline USGS 7 & $4 / 6 / 95$ & 8.7 & 8.7 & .00 & \\
\hline USGS 11 & $10 / 26 / 95$ & 11 & 12 & .84 & \\
\hline USGS 15 & $11 / 7 / 94$ & 6.9 & 7.4 & .53 & \\
\hline
\end{tabular}


Table 12. Comparison of results of replicate pairs of samples from the Idaho National Engineering Laboratory analyzed for chloride-Continued

\begin{tabular}{|c|c|c|c|c|c|}
\hline Site identifier & Date sampled & $\begin{array}{c}\text { Dissolved } \\
\text { chloride } \\
\text { (mg/L) }\end{array}$ & $\begin{array}{c}\text { Dissolved } \\
\text { chloride, QA } \\
(\mathrm{mg} / \mathbf{L})\end{array}$ & Z-value & Remark \\
\hline \multirow[t]{2}{*}{ USGS 17} & $10 / 28 / 94$ & 5.8 & $* 5.9$ & 0.11 & \\
\hline & $11 / 7 / 95$ & 5.7 & 5.7 & .00 & \\
\hline USGS 18 & $7 / 7 / 95$ & 9.7 & 9.4 & .28 & \\
\hline USGS 23 & $10 / 10 / 95$ & 10 & 11 & .88 & \\
\hline USGS 26 & $4 / 11 / 95$ & 13 & 13 & .00 & \\
\hline USGS 29 & $10 / 11 / 94$ & 25 & 27 & 1.02 & \\
\hline USGS 31 & $4 / 01 / 94$ & 22 & 20 & 1.18 & \\
\hline \multirow[t]{2}{*}{ USGS 36} & $1 / 6 / 94$ & 64 & 64 & .00 & \\
\hline & $7 / 14 / 94$ & 65 & 66 & .24 & \\
\hline \multirow[t]{4}{*}{ USGS 39} & $4 / 25 / 94$ & 12 & 12 & .00 & \\
\hline & $7 / 15 / 94$ & 68 & *64 & .97 & \\
\hline & $1 / 20 / 95$ & 12 & 12 & .00 & \\
\hline & $7 / 03 / 95$ & 12 & 12 & .00 & \\
\hline USGS 40 & $1 / 13 / 94$ & 27 & 29 & .97 & \\
\hline USGS 41 & $5 / 3 / 94$ & 25 & 25 & .00 & \\
\hline USGS 42 & $10 / 18 / 94$ & 22 & 23 & .56 & \\
\hline USGS 44 & $10 / 16 / 95$ & 17 & 18 & .66 & \\
\hline \multirow[t]{2}{*}{ USGS 45} & $4 / 13 / 95$ & 20 & 21 & .60 & \\
\hline & $10 / 11 / 95$ & 21 & 21 & .00 & \\
\hline USGS 46 & $4 / 20 / 95$ & 25 & *28 & 1.51 & \\
\hline USGS 47 & $10 / 16 / 95$ & 35 & 36 & .40 & \\
\hline USGS 48 & $4 / 22 / 94$ & 24 & 24 & .00 & \\
\hline USGS 50 & $4 / 13 / 95$ & 68 & 67 & .24 & \\
\hline \multirow[t]{2}{*}{ USGS 51} & $4 / 21 / 94$ & 95 & 93 & .36 & \\
\hline & $4 / 19 / 95$ & 100 & 100 & .00 & \\
\hline USGS 53 & $10 / 25 / 94$ & 17 & 17 & .00 & \\
\hline \multirow[t]{2}{*}{ USGS 55} & $10 / 25 / 94$ & 28 & 28 & .00 & \\
\hline & 10/04/95 & 24 & 24 & .00 & \\
\hline USGS 58 & 4/11/95 & 11 & 11 & .00 & \\
\hline USGS 59 & $10 / 23 / 95$ & 150 & 150 & .00 & \\
\hline USGS 61 & $4 / 28 / 94$ & 14 & $* 14$ & .00 & \\
\hline USGS 62 & $4 / 25 / 94$ & 18 & 18 & .00 & \\
\hline USGS 63 & $4 / 795$ & 20 & 21 & .60 & \\
\hline USGS 65 & $1 / 12 / 94$ & 18 & 18 & .00 & \\
\hline \multirow[t]{2}{*}{ USGS 67} & $4 / 12 / 95$ & 140 & 150 & 1.20 & \\
\hline & $10 / 17 / 95$ & 150 & 150 & .00 & \\
\hline USGS 69 & $7 / 11 / 94$ & 16 & 15 & .71 & \\
\hline
\end{tabular}


Table 12. Comparison of results of replicate pairs of samples from the Idaho National Engineering Laboratory analyzed for chloride-Continued

\begin{tabular}{|c|c|c|c|c|c|}
\hline Site identifier & Date sampled & $\begin{array}{c}\text { Dissolved } \\
\text { chloride } \\
\text { (mg/L) }\end{array}$ & $\begin{array}{c}\text { Dissolved } \\
\text { chloride, QA } \\
(\mathbf{m g} / \mathbf{L})\end{array}$ & $Z$-value & Remark \\
\hline USGS 69-cont. & $7 / 6 / 95$ & 16 & $* 16$ & 0.00 & \\
\hline \multirow[t]{2}{*}{ USGS 70} & $10 / 24 / 94$ & 17 & 19 & 1.30 & \\
\hline & $4 / 12 / 95$ & 20 & 20 & .00 & \\
\hline USGS 78 & $7 / 13 / 95$ & 3.6 & 3.5 & .13 & \\
\hline USGS 79 & $4 / 15 / 94$ & 13 & *12 & .81 & \\
\hline USGS 84 & $10 / 18 / 95$ & 6.7 & *6.8 & .11 & \\
\hline USGS 87 & $1 / 11 / 95$ & 14 & *14 & .00 & \\
\hline USGS 98 & $6 / 12 / 95$ & 15 & 15 & .00 & \\
\hline USGS 99 & $9 / 794$ & 21 & 21 & .00 & \\
\hline USGS 100 & $10 / 19 / 95$ & 16 & 16 & .00 & \\
\hline USGS 101 & $4 / 11 / 94$ & 9 & 14 & 4.20 & N \\
\hline USGS 102 & $9 / 13 / 95$ & 34 & 35 & .41 & \\
\hline USGS 105 & $3 / 31 / 94$ & 14 & 14 & .00 & \\
\hline USGS 108 & $4 / 18 / 95$ & 14 & 14 & .00 & \\
\hline USGS 111 & $4 / 18 / 94$ & 140 & 150 & 1.20 & \\
\hline \multirow[t]{2}{*}{ USGS 112} & $1 / 13 / 94$ & 200 & *190 & .91 & \\
\hline & $10 / 13 / 94$ & 180 & 170 & 1.00 & \\
\hline USGS 113 & $7 / 13 / 94$ & 230 & *220 & .79 & \\
\hline USGS 115 & $7 / 6 / 95$ & 33 & *34 & .42 & \\
\hline \multirow[t]{2}{*}{ USGS 116} & $2 / 1 / 95$ & 110 & 110 & .00 & \\
\hline & $10 / 17 / 95$ & 99 & $* 99$ & .00 & \\
\hline USGS 119 & $10 / 25 / 95$ & 11 & 11 & .00 & \\
\hline USGS 120 & $10 / 23 / 95$ & 20 & 20 & .00 & \\
\hline USGS 121 & $10 / 24 / 94$ & 15 & 15 & .00 & \\
\hline \multirow[t]{2}{*}{ USGS 123} & $10 / 31 / 94$ & 110 & 120 & 1.48 & \\
\hline & $10 / 30 / 95$ & 120 & 120 & .00 & \\
\hline USGS 124 & $4 / 21 / 94$ & 14 & 8.3 & 4.85 & N \\
\hline USGS 125 & $6 / 16 / 95$ & 14 & 14 & .00 & \\
\hline
\end{tabular}


Table 13. Comparison of results of replicate pairs of samples from the Idaho National Engineering Laboratory analyzed for fluoride

[Analyses by the National Water Quality Laboratory. Site identifier: see figures 1-3 for location of sites. Z-value: see section on statistical comparisons for explanation. Remark: no entry, analytical results of replicate pairs are statistically equivalent. Abbreviations: $Q A$, quality-assurance replicate sample; $\mathrm{mg} /$, milligram per liter]

\begin{tabular}{|c|c|c|c|c|c|}
\hline Site identifier & Date sampled & $\begin{array}{c}\text { Dissolved } \\
\text { fluoride } \\
(\mathrm{mg} / \mathrm{L})\end{array}$ & $\begin{array}{c}\text { Dissolved } \\
\text { fluoride, QA } \\
(\mathrm{mg} / \mathrm{L})\end{array}$ & $Z$-value & Remark \\
\hline NRF-1 & $3 / 10 / 94$ & 0.2 & 0.2 & 0.00 & \\
\hline NRF-2 & $11 / 7 / 95$ & .2 & .2 & .00 & \\
\hline NRF-3 & $6 / 8 / 95$ & .2 & .1 & .94 & \\
\hline NRF-6 & $3 / 10 / 95$ & .2 & .2 & .00 & \\
\hline NRF-7 & $6 / 13 / 94$ & .2 & .2 & .00 & \\
\hline WSINEL1 & 6/9/94 & .1 & .2 & .94 & \\
\hline USGS 15 & $11 / 7 / 94$ & .1 & .1 & .00 & \\
\hline USGS 17 & $11 / 7 / 95$ & .3 & .3 & .00 & \\
\hline USGS 98 & $6 / 12 / 95$ & .2 & .2 & .00 & \\
\hline USGS 99 & $9 / / 94$ & .2 & .2 & .00 & \\
\hline USGS 102 & 9/13/95 & .2 & .1 & .94 & \\
\hline USGS 121 & $10 / 24 / 94$ & .2 & .2 & .00 & \\
\hline
\end{tabular}


Table 14. Comparison of results of replicate pairs of samples from the Idaho National Engineering Labora+ory analyzed for bromide

[Analyses by the National Water Quality Laboratory. Site identifier: see figures $1-3$ for location of sites. Z-value: see section on statistical comparisons for explanation. Remark: no entry, analytical results of replicate pairs are statistically equivalent; $N$, anal'tical results of replicate pairs are not statistically equivalent. Abbreviations: QA, quality-assurance replicate sample; mg/L, milligram per liter]

\begin{tabular}{lccccc}
\hline \multicolumn{1}{c}{ Site identifier } & Date sampled & $\begin{array}{c}\text { Dissolved } \\
\text { bromide } \\
(\mathbf{m g} / \mathbf{L})\end{array}$ & $\begin{array}{c}\text { Dissolved } \\
\text { bromide, QA } \\
(\mathbf{m g} / \mathbf{L})\end{array}$ & Z-value & Remark \\
\hline NRF-1 & $3 / 10 / 94$ & 0.05 & 0.08 & .12 & .55 \\
NRF-2 & $11 / 7 / 95$ & .08 & .09 & .55 & .00 \\
NRF-3 & $6 / 8 / 95$ & .09 & .10 & .00 \\
NRF-6 & $3 / 10 / 95$ & .10 & .03 & .21 \\
NRF-7 & $6 / 13 / 94$ & .03 & .22 & .00 \\
WSINEL1 & $6 / 9 / 94$ & .23 & .02 & .00 \\
USGS 15 & $11 / 7 / 94$ & .02 & .02 & 1.04 \\
USGS 17 & $11 / 7 / 95$ & .02 & .05 & .72 \\
USGS 98 & $6 / 12 / 95$ & .04 & .07 & .00 \\
USGS 99 & $9 / 7 / 94$ & .06 & .09 & \\
USGS 102 & $9 / 13 / 95$ & .09 & & .00 \\
\hline
\end{tabular}


Table 15. Comparison of results of replicate pairs of samples from the Idaho National Engineering Laboratory analyzed for nitrite, as nitrogen-Continued

[Analyses by the National Water Quality Laboratory. Site identifier: see figures 1-3 for location of sites. Z-value: see section on statistical comparisons for explanation. Remark: no entry, analytical results of replicate pairs are statistically equivalent; $U$, statistica' equivalence of the analytical results of replicate pairs is uncertain. Abbreviations: QA, quality-assurance replicate sample; mg/L, milligram per liter. Symbols: <, the result was less than the stated value; ", the QA sample was collected within 24 hours of the routine water-quality sample, rather than sequentially]

\begin{tabular}{|c|c|c|c|c|c|}
\hline Site identifier & Date sampled & $\begin{array}{l}\text { Dissolved nitrite, } \\
\text { as nitrogen } \\
(\mathrm{mg} / \mathrm{L})\end{array}$ & $\begin{array}{c}\text { Dissolved nitrite, } \\
\text { as nitrogen, QA } \\
(\mathrm{mg} / \mathrm{L})\end{array}$ & Z-value & Remarks \\
\hline ANP-9 & $10 / 14 / 94$ & $<0.01$ & $<0.01$ & 0 & \\
\hline ARBOR Test & $9 / 29 / 94$ & $<.01$ & $<.01$ & 0 & \\
\hline \multirow[t]{2}{*}{ CFA LF 2-10 } & $11 / 10 / 94$ & $<.01$ & $<.01$ & 0 & \\
\hline & $10 / 25 / 95$ & .02 & $<.01$ & & $\mathrm{U}$ \\
\hline CFA LF 3-9 & $7 / 18 / 95$ & $<.01$ & $<.01$ & 0 & \\
\hline Hwy 3 & $10 / 12 / 94$ & $<.01$ & $*<.01$ & 0 & \\
\hline NPR Test & $4 / 14 / 94$ & $<.01$ & $<.01$ & 0 & \\
\hline NRF-1 & $3 / 10 / 94$ & .01 & $<.01$ & & $\mathrm{U}$ \\
\hline NRF-2 & $11 / 7 / 95$ & $<.01$ & $<.01$ & 0 & \\
\hline NRF-3 & $6 / 08 / 95$ & $<.01$ & $<.01$ & 0 & \\
\hline NRF-6 & $3 / 10 / 95$ & $<.01$ & $<.01$ & 0 & \\
\hline NRF-7 & $6 / 13 / 94$ & $<.01$ & $<.01$ & 0 & \\
\hline PSTF & $4 / 10 / 95$ & $<.01$ & $<.01$ & 0 & \\
\hline Site 17 & $10 / 19 / 94$ & $<.01$ & $<.01$ & 0 & \\
\hline Tan Expl. & $4 / 12 / 94$ & $<.01$ & .02 & & $\mathrm{U}$ \\
\hline WSINEL1 & $6 / 09 / 94$ & $<.01$ & $<.01$ & 0 & \\
\hline USGS 2 & $7 / 13 / 95$ & $<.01$ & $<.01$ & 0 & \\
\hline USGS 4 & $4 / 19 / 95$ & $<.01$ & $<.01$ & 0 & \\
\hline USGS 6 & $7 / 19 / 94$ & $<.01$ & $<.01$ & 0 & \\
\hline USGS 7 & $4 / 6 / 95$ & $<.01$ & $<.01$ & 0 & \\
\hline USGS 11 & $10 / 25 / 95$ & $<.01$ & $<.01$ & 0 & \\
\hline USGS 15 & $11 / 7 / 94$ & $<.01$ & $<.01$ & 0 & \\
\hline \multirow[t]{2}{*}{ USGS 17} & $10 / 28 / 94$ & $<.01$ & $*<.01$ & 0 & \\
\hline & $11 / 7 / 95$ & $<.01$ & $<.01$ & 0 & \\
\hline USGS 18 & $7 / 7 / 95$ & $<.01$ & $<.01$ & 0 & \\
\hline USGS 23 & $10 / 10 / 95$ & $<.01$ & $<.01$ & 0 & . \\
\hline USĞS 26 & $4 / 11 / 95$ & $<.01$ & $<.01$ & 0 & \\
\hline USGS 29 & $10 / 11 / 94$ & $<.01$ & .01 & & $\mathrm{U}$ \\
\hline USGS 31 & $4 / 1 / 94$ & $<.01$ & .01 & & $\mathrm{U}$ \\
\hline USGS 42 & $10 / 18 / 94$ & $<.01$ & $<.01$ & 0 & \\
\hline USGS 44 & $10 / 16 / 95$ & $<.01$ & $<.01$ & 0 & \\
\hline USGS 45 & $10 / 11 / 95$ & $<.01$ & $<.01$ & 0 & \\
\hline USGS 47 & $10 / 16 / 95$ & $<.01$ & $<.01$ & 0 & \\
\hline
\end{tabular}


Table 15. Comparison of results of replicate pairs of samples from the Idaho National Engineering Laboratc $r$ analyzed for nitrite, as nitrogen-Continued

\begin{tabular}{|c|c|c|c|c|c|}
\hline Site identifier & Date sampled & $\begin{array}{l}\text { Dissolved nitrite, } \\
\text { as nitrogen } \\
(\mathrm{mg} / \mathrm{L})\end{array}$ & $\begin{array}{l}\text { Dissolved nitrite, } \\
\text { as nitrogen, } Q A \\
(m g / L)\end{array}$ & Z-value & Remarks \\
\hline USGS 59 & $10 / 23 / 95$ & 0.02 & 0.02 & 0.00 & \\
\hline USGS 67 & $10 / 17 / 95$ & .01 & $<.01$ & & $\mathrm{U}$ \\
\hline USGS 84 & $10 / 18 / 95$ & $<.01$ & $*<.01$ & 0 & \\
\hline USGS 98 & $6 / 12 / 95$ & $<.01$ & $<.01$ & 0 & \\
\hline USGS 99 & $9 / 7 / 94$ & $<.01$ & $<.01$ & 0 & \\
\hline USGS 101 & $4 / 11 / 94$ & .01 & .01 & .00 & \\
\hline USGS 102 & $9 / 13 / 95$ & $<.01$ & $<.01$ & 0 & \\
\hline USGS 105 & $3 / 31 / 94$ & .01 & .01 & .00 & \\
\hline USGS 108 & $4 / 18 / 95$ & $<.01$ & $<.01$ & 0 & \\
\hline USGS 112 & $10 / 13 / 94$ & $<.01$ & $<.01$ & 0 & \\
\hline USGS 116 & $10 / 17 / 95$ & $<.01$ & ${ }^{*}<, 01$ & 0 & \\
\hline USGS 119 & $10 / 25 / 95$ & $<.01$ & $<.01$ & 0 & \\
\hline USGS 120 & $10 / 23 / 95$ & $<.01$ & $<.01$ & 0 & \\
\hline USGS 121 & $10 / 24 / 94$ & $<.01$ & $<.01$ & 0 & \\
\hline \multirow[t]{2}{*}{ USGS 123} & $10 / 31 / 94$ & $<.01$ & $<.01$ & 0 & \\
\hline & $10 / 30 / 95$ & $<.01$ & $<.01$ & 0 & \\
\hline USGS 124 & $4 / 21 / 94$ & $<.01$ & $<.01$ & 0 & \\
\hline USGS 125 & $6 / 16 / 95$ & $<.01$ & $<.01$ & 0 & \\
\hline
\end{tabular}


Table 16. Comparison of results of replicate pairs of samples from the Idaho National Engineering Laboratory analyzed for nitrite plus nitrate, as nitrogen-Continued

[Analyses by the National Water Quality Laboratory. Site identifier: see figures $1-3$ for location of sites. Z-value: see section on statistical comparisons for explanation. Remark: no entry, analytical results of replicate pairs are statistically equivalent; $N$, analytical results of replicate pairs are not statistically equivalent. Abbreviations: QA, quality-assurance replicate sample; $\mathrm{mg} / \mathrm{L}$, milligram per liter. Symbol: *, the QA sample was collected within 24 hours of the routine water-quality sample, rather than sequentially]

\begin{tabular}{|c|c|c|c|c|c|}
\hline Site identifier & Date sampled & $\begin{array}{l}\text { Dissolved nitrite plus } \\
\text { nitrate, as nitrogen } \\
\text { (mg/L) }\end{array}$ & $\begin{array}{l}\text { Dissolved nitrite plus } \\
\text { nitrate, as nitrogen, QA } \\
(\mathrm{mg} / \mathrm{L})\end{array}$ & $Z$-value & Remark \\
\hline ANP-9 & $10 / 14 / 94$ & 0.71 & 0.71 & 0.00 & \\
\hline ARBOR Test & 9/29/94 & 1.1 & 1.3 & 1.36 & \\
\hline \multirow[t]{2}{*}{ CFA LF 2-10 } & $11 / 10 / 94$ & 1.7 & 1.7 & .00 & \\
\hline & $10 / 25 / 95$ & 1.9 & 1.8 & .51 & \\
\hline CFA LF 3-9 & $7 / 18 / 95$ & 3.8 & 3.8 & .00 & \\
\hline Hwy 3 & $10 / 12 / 94$ & .34 & $* .57$ & 2.45 & $\mathrm{~N}$ \\
\hline NPR Test & $4 / 14 / 94$ & 1.4 & 1.2 & 1.29 & \\
\hline NRF-1 & $3 / 10 / 94$ & 1.9 & 1.9 & .00 & \\
\hline NRF-2 & $11 / 7 / 95$ & 2.0 & 2.3 & 1.39 & \\
\hline NRF-3 & 6/08/95 & 1.8 & 1.8 & .00 & \\
\hline NRF-6 & $3 / 10 / 95$ & 1.9 & 1.9 & .00 & \\
\hline NRF-7 & $6 / 13 / 94$ & .43 & .45 & .22 & \\
\hline PSTF & $4 / 10 / 95$ & .59 & .58 & .10 & \\
\hline Site 17 & $10 / 19 / 94$ & 1.1 & 1.1 & .00 & \\
\hline Tan Expl. & $4 / 12 / 94$ & .76 & .80 & .34 & \\
\hline WSINEL1 & $6 / 09 / 94$ & 4.1 & 3.8 & .87 & \\
\hline USGS 2 & $7 / 13 / 95$ & 1.2 & 1.2 & .00 & \\
\hline USGS 4 & $4 / 19 / 95$ & 4.4 & 4.4 & .00 & \\
\hline USGS 6 & $7 / 19 / 94$ & .54 & .52 & .20 & \\
\hline USGS 7 & $4 / 6 / 95$ & .38 & .37 & .11 & \\
\hline USGS 11 & $10 / 26 / 95$ & .55 & .55 & .00 & \\
\hline USGS 15 & $11 / 7 / 94$ & .35 & .34 & .12 & \\
\hline \multirow[t]{2}{*}{ USGS 17} & $10 / 28 / 94$ & .30 & $* .33$ & .36 & \\
\hline & $11 / 7 / 95$ & .34 & .33 & .24 & \\
\hline USGS 18 & $7 / 7 / 95$ & .59 & .59 & .00 & \\
\hline USGS 23 & $10 / 10 / 95$ & .57 & .57 & .00 & \\
\hline USGS 26 & $4 / 11 / 95$ & .78 & .76 & .17 & \\
\hline USGS 29 & 10/11/94 & 1.9 & 1.9 & .00 & \\
\hline USGS 31 & $4 / 1 / 94$ & .9 & .85 & .40 & \\
\hline USGS 42 & $10 / 18 / 94$ & 2.2 & 2.1 & .46 & \\
\hline USGS 44 & $10 / 16 / 95$ & 1.2 & 1.2 & .00 & \\
\hline USGS 45 & $10 / 11 / 95$ & 1.3 & 1.3 & .00 & \\
\hline USGS 47 & $10 / 16 / 95$ & 4.9 & 5.1 & .47 & \\
\hline USGS 59 & $10 / 23 / 95$ & 3.0 & 3.0 & .00 & \\
\hline
\end{tabular}


Table 16. Comparison of results of replicate pairs of samples from the Idaho National Engineering Laboratnry analyzed for nitrite plus nitrate, as nitrogen-Continued

\begin{tabular}{lccccc}
\hline Site identifier & Date sampled & $\begin{array}{c}\text { Dissolved nitrite plus } \\
\text { nitrate, as nitrogen } \\
(\mathbf{m g} / \mathbf{L})\end{array}$ & $\begin{array}{c}\text { Dissolved nitrite plus } \\
\text { nitrate, as nitrogen, QA } \\
(\mathbf{m g} / \mathbf{L})\end{array}$ & Z-value & Remark \\
\hline USGS 67 & $10 / 17 / 95$ & 3.3 & 3.3 & 0.00 \\
USGS 84 & $10 / 18 / 95$ & .82 & $* .83$ & .08 \\
USGS 98 & $6 / 12 / 95$ & 1.0 & 1.0 & .00 \\
USGS 99 & $9 / 7 / 94$ & 1.4 & 1.4 & .00 \\
USGS 101 & $4 / 11 / 94$ & .89 & .89 & .00 \\
USGS 1012 & $9 / 13 / 95$ & 2.0 & 1.9 & .50 \\
USGS 105 & $3 / 31 / 94$ & .63 & .68 & .46 \\
USGS 108 & $4 / 18 / 95$ & .67 & .66 & .09 \\
USGS 112 & $10 / 13 / 94$ & 2.9 & 2.9 & .00 \\
USGS 116 & $10 / 17 / 95$ & 2.8 & $* 2.7$ & .39 \\
USGS 119 & $10 / 25 / 95$ & 1.2 & 1.2 & .00 \\
USGS 120 & $10 / 23 / 95$ & .84 & .83 & .08 \\
USGS 121 & $10 / 24 / 94$ & .82 & .82 & .00 \\
USGS 123 & $10 / 31 / 94$ & 4.1 & 4.2 & .28 \\
& $10 / 30 / 95$ & 3.8 & 3.8 & .00 \\
USGS 124 & $4 / 21 / 94$ & .83 & .79 & .34 \\
USGS 125 & $6 / 16 / 95$ & .57 & .57 & .00 \\
\hline
\end{tabular}


Table 17. Comparison of results of replicate pairs of samples from the Idaho National Engineering Laboratory analyzed for ammonia and ammonia plus organic nitrogen, as nitrogen-Continued

[Analyses by the National Water Quality Laboratory. Site identifier: see figures $1-3$ for location of sites. Z-value: see section on statistical comparisons for explanation. Remark: no entry, analytical results of replicate pairs are statistically equivalent. Abbreviations: $Q A$, quality-assurance replicate sample; $m g / L$, milligram per liter; WWR, whole water, recoverable. Symbols: $<$, the result was less than the stated value; ", the QA sample was collected within 24 hours of the routine water-quality sample, rather than sequentially]

\begin{tabular}{|c|c|c|c|c|c|}
\hline Site identifier & Date sampled & $\begin{array}{l}\text { Dissolved ammonia, } \\
\text { as nitrogen } \\
(\mathrm{mg} / \mathrm{L})\end{array}$ & $\begin{array}{c}\text { Dissolved ammonia, } \\
\text { as nitrogen, } Q A \\
(\mathrm{mg} / \mathrm{L})\end{array}$ & Z-value & Remarks \\
\hline ANP-9 & $10 / 14 / 94$ & $<0.01$ & $<0.01$ & 0 & \\
\hline ARBOR Test & 9/29/94 & .01 & .02 & .44 & \\
\hline \multirow[t]{2}{*}{ CFA LF 2-10 } & $11 / 10 / 94$ & $<.01$ & .01 & 0 & \\
\hline & $10 / 25 / 95$ & .02 & $<.015$ & .22 & \\
\hline CFA LF 3-9 & $7 / 18 / 95$ & .02 & .03 & .42 & \\
\hline Hwy 3 & $10 / 12 / 94$ & .01 & $*<.01$ & 0 & \\
\hline NPR Test & $4 / 14 / 94$ & .01 & .01 & .00 & \\
\hline NRF-1 & $3 / 10 / 94$ & .02 & .03 & .42 & \\
\hline NRF-7 & $6 / 13 / 94$ & $<.01$ & $<.01$ & 0 & \\
\hline PSTF & $4 / 10 / 95$ & $<.015$ & $<.015$ & 0 & \\
\hline Site 17 & $10 / 19 / 94$ & .02 & .02 & .00 & \\
\hline Tan Expl. & $4 / 12 / 94$ & .01 & .01 & .00 & \\
\hline WSINEL1 & $6 / 9 / 94$ & .01 & .02 & .44 & \\
\hline USGS 2 & $7 / 13 / 95$ & .03 & .04 & .40 & \\
\hline USGS 4 & $4 / 19 / 95$ & $<.015$ & $<.015$ & 0 & \\
\hline USGS 6 & $7 / 19 / 94$ & $<.01$ & $<.01$ & 0 & \\
\hline USGS 7 & $4 / 6 / 95$ & .02 & $<.015$ & .22 & \\
\hline USGS 11 & $10 / 26 / 95$ & $<.015$ & $<.015$ & 0 & \\
\hline USGS 15 & $11 / 7 / 94$ & $<.01$ & .01 & 0 & \\
\hline USGS 17 & $10 / 28 / 94$ & $<.015$ & $*<.015$ & 0 & \\
\hline USGS 18 & $7 / 7 / 95$ & .03 & .02 & .42 & \\
\hline USGS 23 & $10 / 10 / 95$ & .02 & .02 & .00 & \\
\hline USGS 26 & $4 / 11 / 95$ & $<.015$ & $<.015$ & 0 & \\
\hline USGS 29 & 10/11/94 & $<.01$ & .02 & .22 & \\
\hline USGS 31 & $4 / 1 / 94$ & .01 & $<.01$ & 0 & \\
\hline USGS 42 & $10 / 18 / 94$ & $<.015$ & .02 & .22 & \\
\hline USGS 44 & $10 / 16 / 95$ & $<.015$ & $<.015$ & 0 & \\
\hline USGS 45 & 10/11/95 & $<.015$ & $<.015$ & 0 & \\
\hline USGS 47 & $10 / 16 / 95$ & $<.015$ & $<.015$ & 0 & \\
\hline USGS 59 & $10 / 23 / 95$ & $<.015$ & $<.015$ & 0 & \\
\hline USGS 67 & 10/17/95 & $<.015$ & $<.015$ & 0 & \\
\hline USGS 84 & $10 / 18 / 95$ & $<.015$ & $*<.015$ & 0 & \\
\hline USGS 99 & $9 / 7 / 94$ & .02 & .02 & .00 & \\
\hline
\end{tabular}


Table 17. Comparison of results of replicate pairs of samples from the Idaho National Engineering Laboratc $y$ analyzed for ammonia and ammonia plus organic nitrogen, as nitrogen-Continued

\begin{tabular}{|c|c|c|c|c|c|}
\hline Site identifier & Date sampled & $\begin{array}{c}\text { Dissolved ammonia, } \\
\text { as nitrogen } \\
(\mathrm{mg} / \mathrm{L})\end{array}$ & $\begin{array}{c}\text { Dissolved ammonia, } \\
\text { as nitrogen, QA } \\
(\mathrm{mg} / \mathrm{L})\end{array}$ & Z-value & Remarks \\
\hline USGS 101 & $4 / 11 / 94$ & $<0.01$ & $<0.01$ & 0 & \\
\hline USGS 105 & $3 / 31 / 94$ & .02 & .01 & .44 & \\
\hline USGS 108 & $4 / 18 / 95$ & $<.015$ & $<.015$ & 0 & \\
\hline USGS 112 & $10 / 13 / 94$ & $<.01$ & .01 & 0 & \\
\hline USGS 116 & $10 / 17 / 95$ & $<.015$ & $*<.015$ & 0 & \\
\hline USGS 119 & $10 / 25 / 95$ & $<.015$ & $<.015$ & 0 & \\
\hline USGS 120 & $10 / 23 / 95$ & $<.015$ & $<.015$ & 0 & \\
\hline USGS 121 & $10 / 24 / 94$ & $<.015$ & $<.015$ & 0 & \\
\hline \multirow[t]{2}{*}{ USGS 123} & $10 / 31 / 94$ & $<.015$ & $<.015$ & 0 & \\
\hline & $10 / 30 / 95$ & $<.015$ & $<.015$ & 0 & \\
\hline USGS 124 & $4 / 21 / 94$ & .01 & .01 & .00 & \\
\hline USGS 125 & $6 / 16 / 95$ & .02 & .02 & .00 & \\
\hline Site identifier & Date sampled & $\begin{array}{l}\text { WWR ammonia, } \\
\text { plus organic nitrogen, } \\
\text { as nitrogen } \\
(\mathrm{mg} / \mathrm{L})\end{array}$ & $\begin{array}{l}\text { WWR ammonia, } \\
\text { plus organic nitrogen, } \\
\text { as nitrogen, QA } \\
(\mathrm{mg} / \mathrm{L})\end{array}$ & Z-value & Remar'ts \\
\hline NRF-2 & $11 / 7 / 95$ & $<.2$ & $<.2$ & 0 & \\
\hline NRF-3 & $6 / 8 / 95$ & $<.2$ & $<.2$ & 0 & \\
\hline NRF-6 & $3 / 10 / 95$ & $<.2$ & $<.2$ & 0 & \\
\hline USGS 17 & $11 / 7 / 95$ & $<.2$ & $<.2$ & 0 & \\
\hline USGS 98 & $6 / 12 / 95$ & $<.2$ & $<.2$ & 0 & \\
\hline USGS 102 & $9 / 13 / 95$ & $<.2$ & $<.2$ & 0 & \\
\hline
\end{tabular}


Table 18. Comparison of results of replicate pairs of samples from the Idaho National Engineering Laboratory analyzed for orthophosphate, as phosphorus; and phosphorus-Continued

[Analyses by the National Water Quality Laboratory. Site identifier. see figures 1-3 for location of sites. Z-value: see section on statistical companisons for explanation. Remark: no entry, analytical results of replicate pairs are statistically equivalent; $N$, analytical results of replicate pairs are not statistically equivalent; $\mathrm{U}$, statistical equivalence of the analytical results of replicate pairs is uncertain. Abbreviations: QA, quality-assurance replicate sample; $\mathrm{mg} / \mathrm{L}$, milligram per liter; WWR, whole water, recoverable. Symbols: <, the result was less than the stated value; *, the QA sample was collected within 24 hours of the routine water-quality sample, rather than sequentiallyl

\begin{tabular}{|c|c|c|c|c|c|}
\hline Site identifier & Date sampled & $\begin{array}{l}\text { Orthophosphate, } \\
\text { as dissolved } \\
\text { phosphorus } \\
\text { (mg/L) }\end{array}$ & $\begin{array}{c}\text { Ortlophosphate, } \\
\text { as dissolved } \\
\text { phosphorus, QA } \\
(\mathrm{mg} / \mathrm{L})\end{array}$ & $Z$-value & Remark \\
\hline ANP-9 & $10 / 14 / 94$ & $<0.01$ & $<0.01$ & 0 & \\
\hline ARBOR Test & $9 / 29 / 94$ & $<.01$ & $<.01$ & 0 & \\
\hline \multirow[t]{2}{*}{ CFA LF 2-10 } & $11 / 10 / 94$ & .02 & .02 & .00 & \\
\hline & $10 / 25 / 95$ & .03 & .03 & .00 & \\
\hline CFA LF 3-9 & $7 / 18 / 95$ & $<.01$ & .02 & & $\mathrm{U}$ \\
\hline Hwy 3 & $10 / 12 / 94$ & .01 & $*<.01$ & & $\mathrm{U}$ \\
\hline NPR Test & $4 / 14 / 94$ & $<.01$ & .01 & & U \\
\hline NRF-1 & $3 / 10 / 94$ & .02 & .02 & .00 & \\
\hline NRF-7 & $6 / 13 / 94$ & .01 & $<.01$ & & $\mathrm{U}$ \\
\hline PSTF & $4 / 10 / 95$ & .02 & .02 & .00 & \\
\hline Site 17 & $10 / 19 / 94$ & .01 & .01 & .00 & \\
\hline Tan Expl. & $4 / 12 / 94$ & .02 & .02 & .00 & \\
\hline WSINEL1 & $6 / 9 / 94$ & .02 & .01 & & U \\
\hline USGS 2 & $7 / 13 / 95$ & .02 & .03 & & $\mathrm{U}$ \\
\hline USGS 4 & $4 / 19 / 95$ & .02 & .02 & .00 & \\
\hline USGS 6 & $7 / 19 / 94$ & .01 & .02 & & U \\
\hline USGS 7 & $4 / 6 / 95$ & $<.01$ & $<.01$ & 0 & \\
\hline USGS 11 & $10 / 26 / 95$ & .01 & .01 & .00 & \\
\hline USGS 15 & $11 / 7 / 94$ & .01 & .02 & & $\mathrm{U}$ \\
\hline USGS 17 & $10 / 28 / 94$ & $<.01$ & $*<.01$ & 0 & \\
\hline USGS 18 & $7 / 7 / 95$ & $<.01$ & $<.01$ & 0 & \\
\hline USGS 23 & $10 / 10 / 95$ & $<.01$ & $<.01$ & 0 & \\
\hline USGS 26 & $4 / 11 / 95$ & $<.01$ & $<.01$ & 0 & \\
\hline USGS 29 & 10/11/94 & $<.01$ & .01 & & $\mathrm{U}$ \\
\hline USGS 31 & $4 / 1 / 94$ & .01 & $<.01$ & & $\mathrm{U}$ \\
\hline USGS 42 & $10 / 18 / 94$ & .02 & .02 & .00 & \\
\hline USGS 44 & $10 / 16 / 95$ & .02 & .02 & .00 & \\
\hline USGS 45 & $10 / 11 / 95$ & .02 & .02 & .00 & \\
\hline USGS 47 & $10 / 16 / 95$ & .04 & .03 & 1.75 & \\
\hline USGS 59 & $10 / 23 / 95$ & .02 & .02 & .00 & \\
\hline USGS 67 & $10 / 17 / 95$ & .03 & .02 & & U \\
\hline USGS 84 & 10/18/95 & .02 & $* .03$ & & $\mathrm{U}$ \\
\hline
\end{tabular}


Table 18. Comparison of results of replicate pairs of samples from the Idaho National Engineering Laboratory analyzed for orthophosphate, as phosphorus; and phosphorus-Continued

\begin{tabular}{|c|c|c|c|c|c|}
\hline Site identifier & Date sampled & $\begin{array}{l}\text { Orthophosphate, } \\
\text { as dissolved } \\
\text { phosphorus } \\
(\mathrm{mg} / \mathrm{L})\end{array}$ & $\begin{array}{c}\text { Orthophosphate, } \\
\text { as dissolved } \\
\text { phosphorus, QA } \\
(\mathrm{mg} / \mathrm{L})\end{array}$ & Z-value & Remark \\
\hline USGS 99 & $9 / 7 / 94$ & $<0.01$ & $<0.01$ & 0 & \\
\hline USGS 101 & $4 / 11 / 94$ & .01 & $<.01$ & & $\mathrm{U}$ \\
\hline USGS 105 & $3 / 31 / 94$ & $<.01$ & .01 & & $\mathrm{U}$ \\
\hline USGS 108 & $4 / 18 / 95$ & .01 & .01 & .00 & \\
\hline USGS 112 & $10 / 13 / 94$ & .02 & .02 & .00 & \\
\hline USGS 116 & $10 / 17 / 95$ & .02 & $* .01$ & & $\mathrm{U}$ \\
\hline USGS 119 & $10 / 25 / 95$ & .01 & $<.01$ & & $\mathbf{U}$ \\
\hline USGS 120 & $10 / 23 / 95$ & .01 & .01 & .00 & \\
\hline USGS 121 & $10 / 24 / 94$ & $<.01$ & $<.01$ & 0 & \\
\hline \multirow[t]{2}{*}{ USGS 123} & $10 / 31 / 94$ & .02 & .02 & .00 & \\
\hline & $10 / 30 / 95$ & .02 & .02 & .00 & \\
\hline USGS 124 & $4 / 21 / 94$ & $<.01$ & $<.01$ & 0 & \\
\hline USGS 125 & $6 / 16 / 95$ & $<.01$ & $<.01$ & 0 & \\
\hline Site identifier & Date sampled & $\begin{array}{c}\text { WWR } \\
\text { phosphorus, } \\
(\mathrm{mg} / \mathrm{L})\end{array}$ & $\begin{array}{c}\text { WWR } \\
\text { phosphorus, QA } \\
(\mathrm{mg} / \mathrm{L})\end{array}$ & $Z$-value & Remark \\
\hline NRF-2 & $11 / 7 / 95$ & $<.01$ & .07 & 2.02 & $\mathbf{N}$ \\
\hline NRF-3 & $6 / 8 / 95$ & .02 & .02 & .00 & \\
\hline NRF-6 & $3 / 16 / 95$ & .09 & .1 & .30 & \\
\hline USGS 17 & $11 / 7 / 95$ & .03 & .06 & 1.00 & \\
\hline USGS 98 & $6 / 12 / 95$ & .03 & .03 & .00 & \\
\hline USGS 102 & $9 / 13 / 95$ & .03 & $<.01$ & 0 & \\
\hline
\end{tabular}


Table 19. Comparison of results of replicate pairs of samples from the Idaho National Engineering Laboratory analyzed for aluminum

[Analyses by the National Water Quality Laboratory. Site identifier: see figures 1-3 for location of sites. Z-value: see section on statistical comparisons for explanation. Remark: no entry, analytical results of replicate pairs are statistically equivalent; $N$, analytical results of replicate pairs are not statistically equivalent; $U$, statistical equivalence of the analytical results of replicate pairs is uncertain. Abbreviations: QA, quality-assurance replicate sample; $\mu \mathrm{g} / \mathrm{L}$, microgram per liter. Symbols: <, the result was less than the stated value; *, the QA sample was collected within 24 hours of the routine water-quality sample, rather than sequentiallyl

\begin{tabular}{lccccc}
\hline \multicolumn{1}{c}{ Site identifier } & Date sampled & $\begin{array}{c}\text { Aluminum } \\
(\mu \mathrm{g} / \mathrm{L})\end{array}$ & $\begin{array}{c}\text { Aluminum, QA } \\
(\mu \mathrm{g} / \mathrm{L})\end{array}$ & Z-value & Remark \\
\hline ANP-9 & $10 / 14 / 94$ & 4 & Dissolved & & \\
PSTF & $4 / 10 / 95$ & 3 & 9 & 0.77 & \\
Tan Expl. & $4 / 12 / 94$ & 4 & 4 & .16 & .16 \\
USGS 7 & $4 / 6 / 95$ & 3 & 3 & .16 & \\
USGS 26 & $4 / 11 / 95$ & 4 & 4 & .00 & \\
USGS 84 & $10 / 18 / 95$ & 5 & 4 & .16 & \\
& & Whole water recoverable & & \\
NRF-2 & $11 / 7 / 95$ & 10 & $<10$ & & $\mathrm{~N}$ \\
NRF-3 & $6 / 8 / 95$ & $<10$ & 30 & 2.53 & \\
NRF-6 & $3 / 10 / 95$ & $<10$ & $<10$ & 0 & $\mathrm{~N}$ \\
USGS 17 & $11 / 7 / 95$ & 20 & 10 & 1.36 & \\
USGS 98 & $6 / 12 / 95$ & 20 & 40 & 2.24 & .00 \\
USGS 102 & $9 / 13 / 95$ & 20 & 20 & & \\
\hline
\end{tabular}


Table 20. Comparison of results of replicate pairs of samples from the Idaho National Engineering Laboratory analyzed for antimony

[Analyses by the National Water Quality Laboratory. Site identifier: see figures $1-3$ for location of sites. Z-value: see section on statistical comparisons for explanation. Remark: no entry, analytical results of replicate pairs are statistically equivalent.

Abbreviations: QA, quality-assurance replicate sample; $\mu \mathrm{g} / \mathrm{h}$, microgram per liter. Symbols: <, the result was less than the stated value; *, the QA sample was collected within 24 hours of the routine water-quality sample, rather than sequentially]

\begin{tabular}{lccccc}
\hline \multicolumn{1}{c}{ Site identifier } & Date sampled & $\begin{array}{c}\text { Antimony } \\
(\mu \mathrm{g} / \mathrm{L})\end{array}$ & $\begin{array}{c}\text { Antimony, QA } \\
(\mu \mathrm{g} / \mathrm{L})\end{array}$ & Z-value & Remark \\
\hline & & & Dissolved & & \\
ANP-9 & $10 / 14 / 94$ & $<1$ & 1 & 0 & 0 \\
PSTF & $4 / 10 / 95$ & $<1$ & $<1$ & 0 \\
Tan Expl. & $4 / 12 / 94$ & $<1$ & $<1$ & 0 \\
USGS 7 & $4 / 6 / 95$ & $<1$ & $<1$ & 0 \\
USGS 26 & $4 / 11 / 95$ & $<1$ & $*<1$ & 0 \\
USGS 84 & $10 / 18 / 95$ & $<1$ & $<1$ & 0 \\
& & Whole water.recoverable & 0 \\
NRF-2 & $11 / 07 / 95$ & $<1$ & $<1$ & 0 \\
NRF-3 & $6 / 08 / 95$ & $<1$ & $<1$ & 0 \\
NRF-6 & $3 / 10 / 95$ & $<1$ & $<1$ & 0 \\
USGS 17 & $11 / 07 / 95$ & $<1$ & $<1$ & 0 \\
USGS 98 & $6 / 12 / 95$ & $<1$ & $<1$ & \\
USGS 102 & $9 / 13 / 95$ & $<1$ & & $<1$ & \\
\hline
\end{tabular}


Table 21. Comparison of results of replicate pairs of samples from the Idaho National Engineering Laboratory analyzed for arsenic

[Analyses by the National Water Quality Laboratory. Site identifier: see figures 1-3 for location of sites. Z-value: see section on statistical comparisons for explanation. Remark: no entry, analytical results of replicate pairs are statistically equivalent.

Abbreviations: QA, quality-assurance replicate sample; $\mu$ g/L, microgram per liter. Symbol: *, the QA sample was collected within 24 hours of the routine water-quality sample, rather than sequentially]

\begin{tabular}{lccccc}
\hline \multicolumn{1}{c}{ Site identifier } & Date sampled & $\begin{array}{c}\text { Arsenic } \\
(\mu \mathbf{g} / \mathbf{L})\end{array}$ & $\begin{array}{c}\text { Arsenic, QA } \\
(\mu \mathbf{g} / \mathbf{L})\end{array}$ & Z-value & Remark \\
\hline & & & Dissolved & & \\
ANP-9 & $10 / 14 / 94$ & 3 & 3 & 0.00 \\
PSTF & $4 / 10 / 95$ & 2 & 2 & .00 \\
Tan Expl. & $4 / 12 / 94$ & 2 & 2 & .00 \\
USGS 7 & $4 / 6 / 95$ & 4 & 4 & .00 \\
USGS 26 & $4 / 11 / 95$ & 2 & 2 & .00 \\
USGS 84 & $10 / 18 / 95$ & 1 & $* 1$ & .00 \\
& & Whole water recoverable & \\
NRF-2 & $11 / 7 / 95$ & 2 & 2 & .00 \\
NRF-3 & $6 / 8 / 95$ & 2 & 1 & .87 \\
NRF-6 & $3 / 10 / 95$ & 3 & 4 & .70 \\
USGS 17 & $11 / 7 / 95$ & 2 & 2 & .00 \\
USGS 98 & $6 / 12 / 95$ & 2 & 2 & .00 \\
USGS 102 & $9 / 13 / 95$ & 2 & 2 & .00 \\
\hline
\end{tabular}


Table 22. Comparison of results of replicate pairs of samples from the Idaho National Engineering Laboratnry analyzed for barium

[Analyses by the National Water Quality Laboratory. Site identifier: see figures 1-3 for location of sites. Z-value: see section on statistical comparisons for explanation. Remark: no entry, analytical results of replicate pairs are statistically equivalent. Abbreviations: QA, quality-assurance replicate sample; $\mu \mathrm{g} / \mathrm{L}$, microgram per liter. Symbols: <, the result was less than the stated value; *, the QA sample was collected within 24 hours of the routine water-quality sample, rather than sequentially]

\begin{tabular}{lccccc}
\hline Site identifier & Date sampled & $\begin{array}{c}\text { Barium } \\
(\mu \mathrm{g} / \mathrm{L})\end{array}$ & $\begin{array}{c}\text { Barium, QA } \\
(\mu \mathrm{g} / \mathrm{L})\end{array}$ & Z-value & Remark \\
\hline & & & Dissolved & & \\
ANP-9 & $10 / 14 / 94$ & 85 & 90 & 1.35 \\
PSTF & $4 / 10 / 95$ & 67 & 67 & .00 \\
Tan Expl. & $4 / 12 / 94$ & 68 & 67 & .35 \\
USGS 7 & $4 / 6 / 95$ & 16 & 16 & .00 \\
USGS 26 & $4 / 11 / 95$ & 37 & 36 & .24 \\
USGS 84 & $10 / 18 / 95$ & 84 & $* 83$ & .25 \\
& & Whole water, recoverable & \\
NRF-2 & $11 / 7 / 95$ & 200 & 100 & .94 \\
NRF-3 & $6 / 8 / 95$ & 200 & $<100$ & .94 \\
NRF-6 & $3 / 10 / 95$ & 100 & 100 & .00 \\
USGS 17 & $11 / 7 / 95$ & $<100$ & $<100$ & 0 \\
USGS 98 & $6 / 12 / 95$ & $<100$ & $<100$ & 0 \\
USGS 102 & $9 / 13 / 95$ & $<100$ & $<100$ & 0 \\
\hline
\end{tabular}


Table 23. Comparison of results of replicate pairs of samples from the Idaho National Engineering Laboratory analyzed for beryllium

[Analyses by the National Water Quality Laboratory. Site identifier. see figures 1-3 for location of sites. Z-value: see section on statistical comparisons for explanation. Remark: no entry, analytical results of replicate pairs are statistically equivalent. Abbreviations: QA, quality-assurance replicate sample; $\mu \mathrm{g} / \mathrm{L}$, microgram per liter. Symbols: <, the result was less than the stated value; ", the QA sample was collected within 24 hours of the routine water-quality sample, rather than sequentially]

\begin{tabular}{lccccc}
\hline \multicolumn{1}{c}{ Site identifier } & Date sampled & $\begin{array}{c}\text { Beryllium } \\
(\mu \mathbf{g} / \mathbf{L})\end{array}$ & $\begin{array}{c}\text { Beryllium, QA } \\
(\mu \mathbf{g} / \mathbf{L})\end{array}$ & Z-value & Remark \\
\hline & & & Dissolved & & \\
ANP-9 & $10 / 14 / 94$ & $<1$ & $<1$ & 0 \\
PSTF & $4 / 10 / 95$ & $<1$ & $<1$ & 0 \\
Tan Expl. & $4 / 12 / 94$ & $<1$ & $<1$ & 0 \\
USGS 7 & $4 / 6 / 95$ & $<1$ & $<1$ & 0 \\
USGS 26 & $4 / 11 / 95$ & $<1$ & $<1$ & 0 \\
USGS84 & $10 / 18 / 95$ & $<1$ & $*<1$ & 0 \\
& & Whole water recoverable & \\
NRF-2 & $11 / 7 / 95$ & $<10$ & $<10$ & 0 \\
NRF-3 & $6 / 8 / 95$ & $<10$ & $<10$ & 0 \\
NRF-6 & $3 / 10 / 95$ & $<10$ & $<10$ & 0 \\
USGS 17 & $11 / 7 / 95$ & $<10$ & $<10$ & 0 \\
USGS 98 & $6 / 12 / 95$ & $<10$ & $<10$ & 0 \\
USGS 102 & $9 / 13 / 95$ & $<10$ & $<10$ & 0 \\
\hline
\end{tabular}


Table 24. Comparison of results of replicate pairs of samples from the Idaho National Engineering Laboratnry analyzed for cadmium

[Analyses by the National Water Quality Laboratory. Site identifier: see figures 1-3 for location of sites. Z-value: see section on statistical comparisons for explanation. Remark: no entry, analytical results of replicate pairs are statistically equivalent. Abbreviations: QA, quality-assurance replicate sample; $\mu \mathrm{g} / \mathrm{L}$, microgram per liter. Symbols: <, the result was less than the stated value; *, the QA sample was collected within 24 hours of the routine water-quality sample, rather than sequentially]

\begin{tabular}{lccccc}
\hline Site identifier & Date sampled & $\begin{array}{c}\text { Cadmium } \\
(\mu \mathrm{g} / \mathrm{L})\end{array}$ & $\begin{array}{c}\text { Cadmium, QA } \\
(\mu \mathrm{g} / \mathrm{L})\end{array}$ & Z-value & Remark \\
\hline & & & Dissolved & & \\
ANP-9 & $10 / 14 / 94$ & $<1$ & $<1$ & 0 \\
PSTF & $4 / 10 / 95$ & $<1$ & $<1$ & 0 \\
Tan Expl. & $4 / 12 / 94$ & $<1$ & $<1$ & 0 \\
USGS 7 & $4 / 6 / 95$ & $<1$ & $<1$ & 0 \\
USGS 26 & $4 / 11 / 95$ & $<1$ & $<1$ & 0 \\
USGS 84 & $10 / 18 / 95$ & $<1$ & $*<1$ & 0 \\
& & Whole water recoverable & \\
NRF-2 & $11 / 7 / 95$ & $<1$ & $<1$ & 0 \\
NRF-3 & $6 / 8 / 95$ & $<1$ & $<1$ & 0 \\
NRF-6 & $3 / 10 / 95$ & $<1$ & 1 & 0 \\
USGS 17 & $11 / 7 / 95$ & $<1$ & $<1$ & 0 \\
USGS 98 & $6 / 12 / 95$ & $<1$ & $<1$ & 0 \\
USGS 102 & $9 / 13 / 95$ & $<1$ & $<1$ & 0 \\
\hline
\end{tabular}




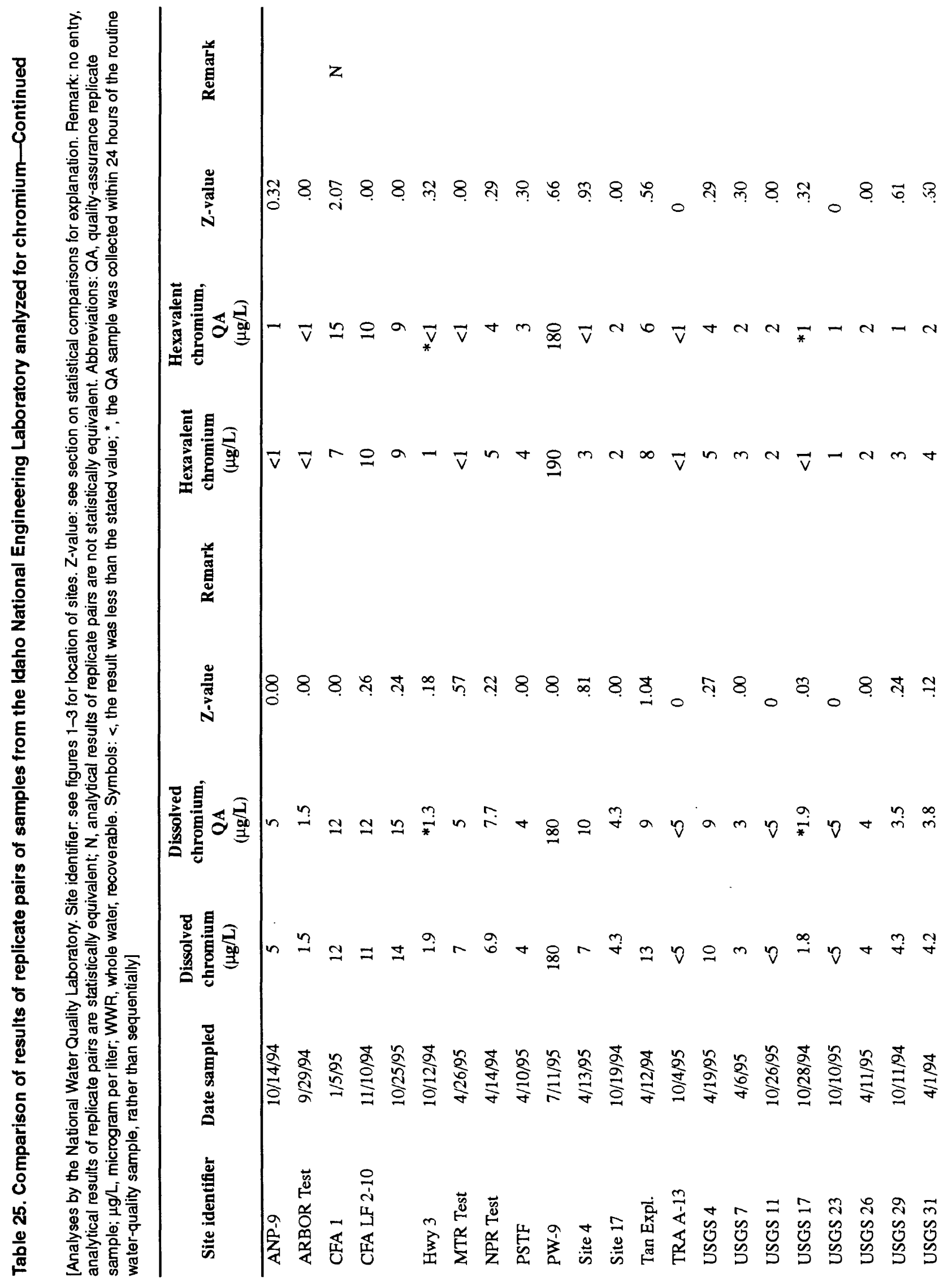




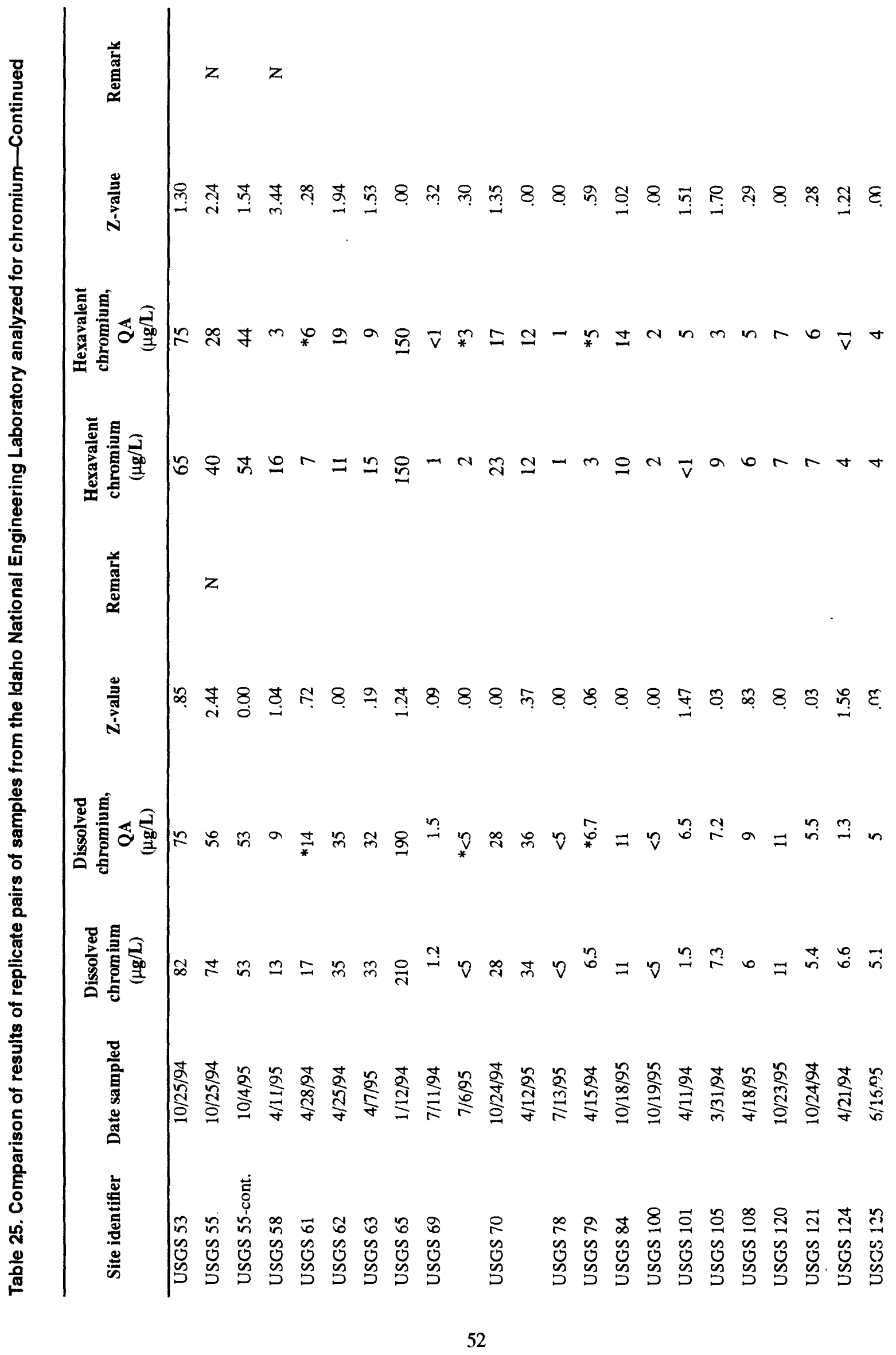




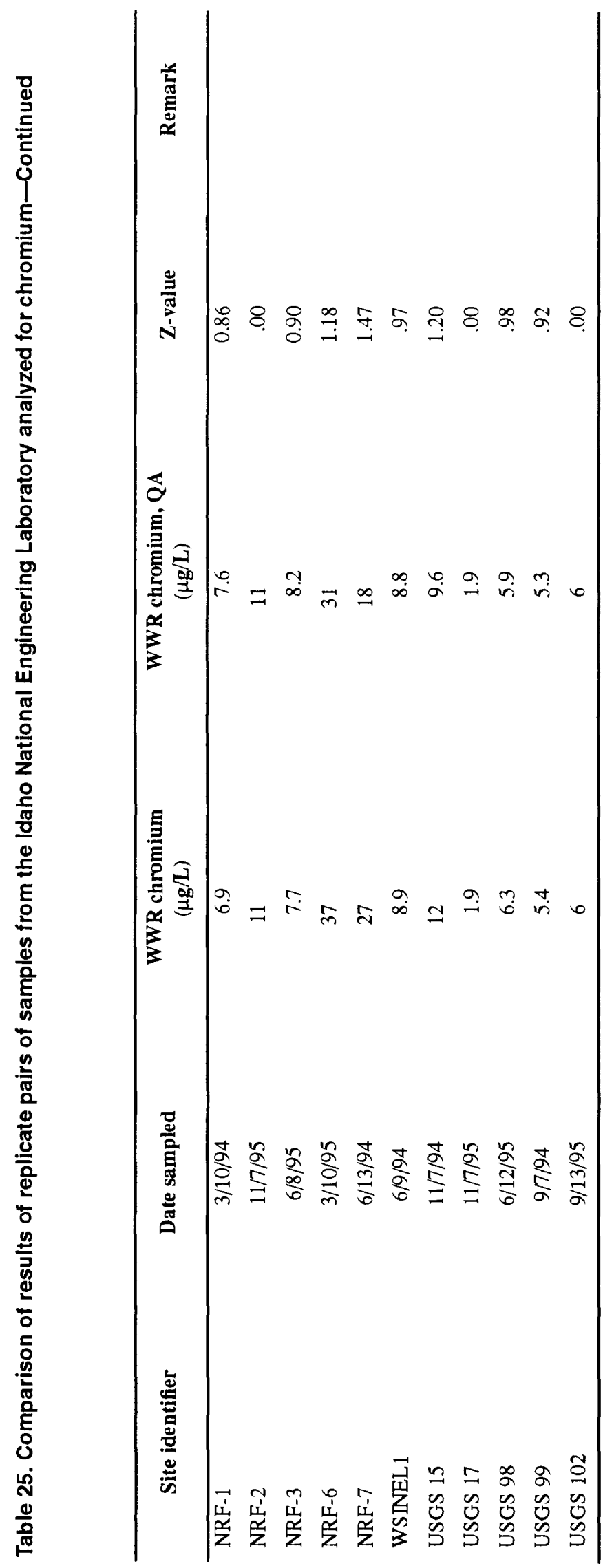


Table 26. Comparison of results of replicate pairs of samples from the Idaho National Engineering Laboratory analyzed for cobalt

[Analyses by the National Water Quality Laboratory. Site identifier: see figures 1-3 for location of sites. Z-value: see section on statistical comparisons for explanation. Remark: no entry, analytical results of replicate pairs are statistically equivalent.

Abbreviations: QA, quality-assurance replicate sample; $\mu \mathrm{g} / \mathrm{L}$, microgram per liter. Symbols: <, the result was less than the stated value; *, the QA sample was collected within 24 hours of the routine water-quality sample, rather than sequentially]

\begin{tabular}{lccccc}
\hline Site identifier & Date sampled & $\begin{array}{c}\text { Dissolved } \\
\text { cobalt } \\
(\mu \mathbf{g} / \mathbf{L})\end{array}$ & $\begin{array}{c}\text { Dissolved } \\
\text { cobalt, } \mathbf{Q A} \\
(\mu \mathbf{g} / \mathbf{L})\end{array}$ & Z-value & Remark \\
\hline ANP-9 & $10 / 14 / 94$ & $<1$ & $<1$ & 0 \\
PSTF & $4 / 10 / 95$ & $<1$ & $<1$ & 0 \\
Tan Expl. & $4 / 12 / 94$ & $<1$ & $<1$ & 0 \\
USGS 7 & $4 / 6 / 95$ & $<1$ & $<1$ & 0 \\
USGS 26 & $4 / 11 / 95$ & $<1$ & $<1$ & 0 \\
USGS 84 & $10 / 18 / 95$ & $<1$ & $*<1$ & 0 \\
\hline
\end{tabular}


Table 27. Comparison of results of replicate pairs of samples from the Idaho National Engineering Laboratory analyzed for copper

[Analyses by the National Water Quality Laboratory. .Site identifier: see figures 1-3 for location of sites. Z-value: see section on statistical companisons for explanation. Remark: no entry, analytical results of replicate pairs are statistically equivalent; $N$, analytical results of replicate pairs are not statistically equivalent. Abbreviations: QA, quality-assurance replicate sample; $\mu \mathrm{g} / \mathrm{L}$, microgram per liter. Symbols: <, the result was less than the stated value; *, the QA sample was collected within 24 hours of the routine water-quality sample, rather than sequentially]

\begin{tabular}{|c|c|c|c|c|c|}
\hline Site identifier & Date sampled & $\begin{array}{l}\text { Copper } \\
(\mu \mathrm{g} / \mathrm{L})\end{array}$ & $\begin{array}{c}\text { Copper, QA } \\
(\mu \mathrm{g} / \mathrm{L})\end{array}$ & $Z$-value & Remark \\
\hline \multicolumn{6}{|c|}{ Dissolved } \\
\hline ANP-9 & $10 / 14 / 94$ & $<1$ & $<1$ & 0 & \\
\hline PSTF & $4 / 10 / 95$ & $<1$ & $<1$ & 0 & \\
\hline Tan Expl. & $4 / 12 / 94$ & $<1$ & $<1$ & 0 & \\
\hline USGS 7 & $4 / 6 / 95$ & $<1$ & $<1$ & 0 & \\
\hline USGS 26 & $4 / 11 / 95$ & $<1$ & $<1$ & 0 & \\
\hline USGS 84 & $10 / 18 / 95$ & 1 & *2 & .33 & \\
\hline \multicolumn{6}{|c|}{ Whole water, recoverable } \\
\hline NRF-2 & $11 / 7 / 95$ & 1 & 19 & 4.72 & $\mathrm{~N}$ \\
\hline NRF-3 & 6/8/95 & 3 & 4 & .31 & \\
\hline NRF-6 & $3 / 10 / 95$ & 1 & 3 & .64 & \\
\hline USGS 17 & $11 / 7 / 95$ & $<1$ & $<1$ & 0 & \\
\hline USGS 98 & $6 / 12 / 95$ & 4 & 6 & .60 & \\
\hline USGS 102 & 9/13/95 & 2 & $<1$ & .33 & \\
\hline
\end{tabular}


Table 28. Comparison of results of replicate pairs of samples from the Idaho National Engineering Laboratory analyzed for iron

[Analyses by the National Water Quality Laboratory. Site identifier: see figures $1-3$ for location of sites. Z-value: see Statistical Comparisons of Replicate Pairs of Samples section for explanation. Remark: no entry, analytical results of replicate pairs are statistically equivalent; $\mathrm{N}$, analytical results of replicate pairs are not statistically equivalent. Abbreviations: WWR, whole water, recoverable; QA, quality-assurance replicate sample; $\mu \mathrm{g} / \mathrm{L}$, microgram per liter. Symbols: $<$, the result was less than the stated value]

\begin{tabular}{lccccc}
\hline \multicolumn{1}{c}{ Site identifier } & Date sampled & $\begin{array}{c}\text { WWR iron } \\
(\mu \mathrm{g} / \mathbf{L})\end{array}$ & $\begin{array}{c}\text { WWR iron, QA } \\
(\mu \mathrm{g} / \mathbf{L})\end{array}$ & Z-value & Remark \\
\hline NRF-1 & $3 / 10 / 94$ & 30 & $<10$ & 1.38 & \\
NRF-2 & $11 / 7 / 95$ & 30 & $<10$ & 1.38 & \\
NRF-3 & $6 / 8 / 95$ & 320 & 460 & 4.32 & $\mathrm{~N}$ \\
NRF-6 & $3 / 10 / 95$ & 800 & 410 & 8.94 & $\mathrm{~N}$ \\
NRF-7 & $6 / 13 / 94$ & 4800 & 1200 & 20.01 & $\mathrm{~N}$ \\
WSINEL1 & $6 / 9 / 94$ & 4000 & 2600 & 7.98 & $\mathrm{~N}$ \\
USGS 15 & $11 / 7 / 94$ & 480 & 540 & 1.58 & \\
USGS 17 & $11 / 7 / 95$ & 40 & 30 & .66 & \\
USGS 98 & $6 / 12 / 95$ & 1300 & 670 & 10.05 & $\mathrm{~N}$ \\
USGS 99 & $97 / 94$ & 580 & 360 & 6.03 & $\mathrm{~N}$ \\
USGS 102 & $9 / 13 / 95$ & 450 & 600 & 3.86 & $\mathrm{~N}$ \\
\hline
\end{tabular}


Table 29. Comparison of results of replicate pairs of samples from the Idaho National Engineering Laboratory analyzed for lead

[Analyses by the National Water Quality Laboratory. Site identifier: see figures 1-3 for location of sites. Z-value: see section on statistical comparisons for explanation. Remark: no entry, analytical results of replicate pairs are statistically equivalent. Abbreviations: QA, quality-assurance replicate sample; $\mu \mathrm{g} / \mathrm{L}$, microgram per liter. Symbols: $<$, the result was less than the stated value; *, the QA sample was collected within 24 hours of the routine water-quality sample, rather than sequentially]

\begin{tabular}{|c|c|c|c|c|c|}
\hline Site identifier & Date sampled & $\begin{array}{l}\text { Lead } \\
(\mu \mathrm{g} / \mathrm{L})\end{array}$ & $\begin{array}{c}\text { Lead, QA } \\
(\mu \mathrm{g} / \mathbf{L})\end{array}$ & Z-value & Remark \\
\hline \multicolumn{6}{|c|}{ Dissolved } \\
\hline ANP-9 & 10/14/94 & $<1$ & $<1$ & 0 & \\
\hline PSTF & $4 / 10 / 95$ & $<1$ & $<1$ & 0 & \\
\hline Tan Expl. & $4 / 12 / 94$ & $<1$ & $<1$ & 0 & \\
\hline USGS 7 & $4 / 6 / 95$ & $<1$ & $<1$ & 0 & \\
\hline USGS 26 & $4 / 11 / 95$ & $<1$ & $<1$ & 0 & \\
\hline USGS 84 & 10/18/95 & 16 & $* 14$ & .39 & \\
\hline \multicolumn{6}{|c|}{ Whole water recoverable } \\
\hline NRF-1 & $3 / 10 / 94$ & $<1$ & $<1$ & 0 & \\
\hline NRF-2 & $11 / 07 / 95$ & $<1$ & $<1$ & 0 & \\
\hline NRF-3 & $6 / 08 / 95$ & 2 & 1 & .31 & \\
\hline NRF-6 & $3 / 10 / 95$ & $<1$ & 1 & 0 & \\
\hline NRF-7 & $6 / 13 / 94$ & $<1$ & $<1$ & 0 & \\
\hline WSINEL1 & 6/09/94 & 4 & 4 & .00 & \\
\hline USGS 15 & $11 / 07 / 94$ & $<1$ & $<1$ & 0 & \\
\hline USGS 17 & $11 / 07 / 95$ & $<1$ & $<1$ & 0 & \\
\hline USGS 98 & $6 / 12 / 95$ & 9 & 9 & .00 & \\
\hline USGS 99 & $9 / 07 / 94$ & 5 & 2 & .86 & \\
\hline USGS 102 & 9/13/95 & $<1$ & $<1$ & 0 & \\
\hline
\end{tabular}


Table 30. Comparison of results of replicate pairs of samples from the Idaho National Engineering Laboratoy analyzed for manganese

[Analyses by the National Water Quality Laboratory. Site identifier: see figures $1-3$ for location of sites. Z-value: see section on statistical comparisons for explanation. Remark: no entry, analytical results of replicate pairs are statistically oquivalent. Abbreviations: $Q A$, quality-assurance replicate sample; $\mu \mathrm{g} / \mathrm{L}$, microgram per liter. Symbols: $<$, the result was less than the stated value; *, the QA sample was collected within 24 hours of the routine water-quality sample rather than sequentially]

\begin{tabular}{lccccc}
\hline \multicolumn{1}{c}{ Site identifier } & Date sampled & $\begin{array}{c}\text { Manganese } \\
(\mu \mathbf{g} / \mathbf{L})\end{array}$ & $\begin{array}{c}\text { Manganese, } \mathbf{Q A} \\
(\mu \mathbf{g} / \mathbf{L})\end{array}$ & Z-value & Remark \\
\hline & & & Dissolved & & \\
ANP-9 & $10 / 14 / 94$ & 2 & 2 & 0.00 \\
Tan Expl. & $4 / 12 / 94$ & $<1$ & $<1$ & 0 \\
PSTF & $4 / 10 / 95$ & $<1$ & $<1$ & 0 \\
USGS 7 & $4 / 6 / 95$ & 2 & 2 & .00 \\
USGS 26 & $4 / 11 / 95$ & $<1$ & $<1$ & 0 \\
USGS 84 & $10 / 18 / 95$ & $<1$ & $* 1$ & 0 \\
& & Whole water. recoverable & \\
NRF-2 & $11 / 7 / 95$ & $<10$ & $<10$ & 0 \\
NRF-3 & $6 / 8 / 95$ & $<10$ & $<10$ & 0 \\
NRF-6 & $3 / 10 / 95$ & 10 & 10 & .00 \\
USGS 17 & $11 / 7 / 95$ & $<10$ & $<10$ & 0 \\
USGS 98 & $6 / 12 / 95$ & $<10$ & $<10$ & 0 \\
USGS 102 & $9 / 13 / 95$ & $<10$ & $<10$ & 0 \\
\hline
\end{tabular}


Table 31. Comparison of results of replicate pairs of samples from the Idaho National Engineering Laboratory analyzed for mercury

[Analyses by the National Water Quality Laboratory. Site identifier: see figures 1-3 for location of sites. Z-value: see section on statistical comparisons for explanation. Remark: no entry, analytical results of replicate pairs are statistically equivalent.

Abbreviations: $Q A$, quality-assurance replicate sample; $\mu \mathrm{g} / \mathrm{L}$, microgram per liter. Symbols: <, the result was less than the stated value; *, the QA sample was collected within 24 hours of the routine water-quality sample, rather than sequentially]

\begin{tabular}{|c|c|c|c|c|c|}
\hline Site identifier & Date sampled & $\begin{array}{c}\text { Mercury } \\
(\mu \mathrm{g} / \mathrm{L})\end{array}$ & $\begin{array}{c}\text { Mercury, QA } \\
(\mu \mathrm{g} / \mathrm{L})\end{array}$ & $Z$-value & Remark \\
\hline \multicolumn{6}{|c|}{ Dissolved } \\
\hline PSTF & $4 / 10 / 95$ & $<0.1$ & 0.1 & 0 & \\
\hline Tan Expl. & $4 / 12 / 94$ & $<.1$ & $<.1$ & 0 & \\
\hline USGS 7 & $4 / 6 / 95$ & $<.1$ & $<.1$ & 0 & \\
\hline USGS 26 & $4 / 11 / 95$ & $<.1$ & $<.1$ & 0 & \\
\hline USGS 84 & $10 / 18 / 95$ & $<.1$ & $*<.1$ & 0 & \\
\hline \multicolumn{6}{|c|}{ Whole water recoverable } \\
\hline NRF-1 & $3 / 10 / 94$ & $<.1$ & $<.1$ & 0 & \\
\hline NRF-2 & $11 / 7 / 95$ & $<.1$ & .1 & 0 & \\
\hline NRF-3 & 6/8/95 & $<.1$ & $<.1$ & 0 & \\
\hline NRF-6 & $3 / 10 / 95$ & $<.2$ & $<.2$ & 0 & \\
\hline NRF-7 & $6 / 13 / 94$ & $<.1$ & $<.1$ & 0 & \\
\hline WSINEL1 & 6/9/94 & $<.1$ & $<.1$ & 0 & \\
\hline USGS 15 & $11 / 7 / 94$ & $<.1$ & $<.1$ & 0 & \\
\hline USGS 17 & $11 / 7 / 95$ & $<.1$ & $<.1$ & 0 & \\
\hline USGS 98 & $6 / 12 / 95$ & $<.1$ & $<.1$ & 0 & \\
\hline USGS 99 & $9 / 7 / 94$ & $<.1$ & $<.1$ & 0 & \\
\hline USGS 102 & $9 / 13 / 95$ & $<.1$ & $<.1$ & 0 & \\
\hline
\end{tabular}


Table 32. Comparison of results of replicate pairs of samples from the Idaho National Engineering Laborato $y$ analyzed for molybdenum

[Analyses by the National Water Quality Laboratory. Site identifier. see figures 1-3 for location of sites. Z-value: see section on statistical comparisons for explanation. Remark: no entry, analytical results of replicate pairs are statistically equivalent.

Abbreviations: QA, quality-assurance replicate sample; $\mu \mathrm{g} / \mathrm{L}$, microgram per liter. Symbol: *, the QA sample was collected within 24 hours of the routine water-quality sample, rather than sequentially]

\begin{tabular}{|c|c|c|c|c|c|}
\hline Site identifier & Date sampled & $\begin{array}{c}\text { Dissolved } \\
\text { molybdenum } \\
(\mu \mathrm{g} / \mathrm{L})\end{array}$ & $\begin{array}{c}\text { Dissolved } \\
\text { molybdenum, QA } \\
(\mu \mathrm{g} / \mathrm{L})\end{array}$ & $Z$-value & Remark \\
\hline ANP-9 & $10 / 14 / 94$ & 4 & 3 & 0.27 & \\
\hline PSTF & $4 / 10 / 95$ & 2 & 2 & .00 & \\
\hline Tan Expl. & $4 / 12 / 94$ & 6 & 6 & .00 & \\
\hline USGS 7 & $4 / 6 / 95$ & 4 & 4 & .00 & \\
\hline USGS 26 & $4 / 11 / 95$ & 3 & 3 & .00 & \\
\hline USGS 84 & $10 / 18 / 95$ & 2 & $* 2$ & .00 & \\
\hline
\end{tabular}


Table 33. Comparison of results of replicate pairs of samples from the Idaho National Engineering Laboraton! analyzed for nickel

IAnalyses by the National Water Quality Laboratory. Site identifier: see figures 1-3 for location of sites. Z-value: see section on statistical comparisons for explanation. Remark: no entry, analytical results of replicate pairs are statistically equivalent.

Abbreviations: QA, quality-assurance replicate sample; $\mu \mathrm{g} / \mathrm{L}$, microgram per liter. Symbols: <, the result was less than the stated value; *, the QA sample was collected within 24 hours of the routine water-quality sample, rather than sequentially]

\begin{tabular}{|c|c|c|c|c|c|}
\hline Site identifier & Date sampled & $\begin{array}{l}\text { Nickel } \\
(\mu \mathrm{g} / \mathrm{L})\end{array}$ & $\begin{array}{c}\text { Nickel, QA } \\
(\mu \mathrm{g} / \mathrm{L})\end{array}$ & $Z$-value & Remark \\
\hline \multicolumn{6}{|c|}{ Dissolved } \\
\hline ANP-9 & $10 / 14 / 94$ & $<1$ & $<1$ & 0 & \\
\hline PSTF & $4 / 10 / 95$ & 1 & 1 & .00 & \\
\hline Tan Expl. & $4 / 12 / 94$ & $<1$ & $<1$ & 0 & \\
\hline USGS 7 & $4 / 6 / 95$ & 1 & 1 & .00 & \\
\hline USGS 26 & $4 / 11 / 95$ & 1 & 1 & .00 & \\
\hline USGS 84 & $10 / 18 / 95$ & $<1$ & $* 1$ & 0 & \\
\hline \multicolumn{6}{|c|}{ Whole water recoverable } \\
\hline NRF-1 & $3 / 10 / 94$ & $<1$ & $<1$ & 0 & \\
\hline NRF-2 & $11 / 7 / 95$ & $<1$ & 2 & .28 & \\
\hline NRF-3 & 6/8/95 & $<1$ & $<1$ & 0 & \\
\hline NRF-6 & $3 / 10 / 95$ & 12 & 12 & .00 & \\
\hline NRF-7 & $6 / 13 / 94$ & 17 & 9 & 1.71 & \\
\hline WSINEL1 & $6 / 9 / 94$ & $<1$ & $<1$ & 0 & \\
\hline USGS 15 & $11 / 7 / 94$ & 2 & 2 & .00 & \\
\hline USGS 17 & $11 / 7 / 95$ & $<1$ & $<1$ & 0 & \\
\hline USGS 98 & $6 / 12 / 95$ & $<1$ & 1 & 0 & \\
\hline USGS 99 & $9 / 7 / 94$ & 5 & 6 & .26 & \\
\hline USGS 102 & $9 / 13 / 95$ & $<1$ & $<1$ & 0 & \\
\hline
\end{tabular}


Table 34. Comparison of results of replicate pairs of samples from the Idaho National Engineering Laboratory analyzed for selenium

[Analyses by the National Water Quality Laboratory. Site identifier: see figures $1-3$ for location of sites. Z-value: see section on statistical comparisons for explanation. Remark: no entry, analytical results of replicate pairs are statistically equivalent. Abbreviations: WWR, whole water, recoverable; $Q A$, quality-assurance replicate sample; $\mu \mathrm{g} / \mathrm{L}$, microgram per liter. Symbol: *, the QA sample was collected within 24 hours of the routine water-quality sample, rather than sequentially]

\begin{tabular}{lccccc}
\hline Site identifier & Date sampled & $\begin{array}{c}\text { WWR selenium } \\
(\mu \mathrm{g} / \mathbf{L})\end{array}$ & $\begin{array}{c}\text { WWR selenium, QA } \\
(\mu \mathrm{g} / \mathbf{L})\end{array}$ & Z-value & Remark \\
\hline NRF-2 & $11 / 7 / 95$ & 2 & 2 & 0.00 \\
NRF-3 & $6 / 8 / 95$ & 2 & 2 & .00 \\
NRF-6 & $3 / 10 / 95$ & 2 & 3 & .67 \\
USGS 17 & $11 / 7 / 95$ & 1 & 1 & .00 \\
USGS 98 & $6 / 12 / 95$ & 1 & 1 & .00 \\
USGS 102 & $9 / 13 / 95$ & 2 & 2 & .00 \\
\hline
\end{tabular}


Table 35. Comparison of results of replicate pairs of samples from the Idaho National Engineering Laboratory analyzed for silver

[Analyses by the National Water Quality Laboratory. Site identifier: see figures 1-3 for location of sites. Z-value: see section on statistical comparisons for explanation. Remark: no entry, analytical results of replicate pairs are statistically equivalent. Abbreviations: $Q A$, quality-assurance replicate sample; $\mu g / L$, microgram per liter. Symbols: $<$, the result was less than the stated value; ", the QA sample was collected within 24 hours of the routine water-quality sample, rather than sequentiallyl

\begin{tabular}{lccccc}
\hline Site identifier & Date sampled & $\begin{array}{c}\text { Silver } \\
(\mu \mathbf{g} / \mathbf{L})\end{array}$ & $\begin{array}{c}\text { Silver, QA } \\
(\mu \mathbf{g} / \mathbf{L})\end{array}$ & Z-value & Remark \\
\hline ANP-9 & & & Dissolved & & \\
PSTF & $10 / 14 / 94$ & $<1$ & $<1$ & 0 & 0 \\
Tan Expl. & $4 / 10 / 95$ & $<1$ & $<1$ & 0 \\
USGS 7 & $4 / 12 / 94$ & $<1$ & $<1$ & 0 \\
USGS 26 & $4 / 6 / 95$ & $<1$ & $<1$ & 0 \\
USGS 84 & $4 / 11 / 95$ & $<1$ & $* 1$ & .00 \\
& $10 / 18 / 95$ & 1 & $<1$ & 0 \\
NRF-1 & & Wholewater recoverable & 0 \\
NRF-2 & $3 / 10 / 94$ & $<1$ & $<1$ & 0 \\
NRF-3 & $11 / 7 / 95$ & $<1$ & $<1$ & 0 \\
NRF-6 & $6 / 8 / 95$ & $<1$ & $<1$ & 0 \\
NRF-7 & $3 / 10 / 95$ & $<1$ & $<1$ & 0 \\
WSINEL1 & $6 / 13 / 94$ & $<1$ & $<1$ & 0 \\
USGS 15 & $6 / 09 / 94$ & $<1$ & $<1$ & 0 \\
USGS 17 & $11 / 7 / 94$ & $<1$ & $<1$ & 0 \\
USGS 98 & $11 / 7 / 95$ & $<1$ & $<1$ & 0 \\
USGS 99 & $6 / 12 / 95$ & $<1$ & $<1$ & 0 \\
USGS 102 & $9 / 7 / 94$ & $<1$ & $<1$ & & \\
\hline
\end{tabular}


Table 36. Comparison of results of replicate pairs of samples from the Idaho National Engineering Laborator' analyzed for thallium

[Analyses by the National Water Quality Laboratory. Site identifier: see figures 1-3 for location of sites. Z-value: see section on statistical comparisons for explanation. Remark: no entry, analytical results of replicate pairs are statistically equivalent; $U$, statistical equivalence of the analytical results of replicate pairs is uncertain. Abbreviations: $Q A$, quality-assurance replicate sample; $\mu \mathrm{g} / \mathrm{L}$, microgram per liter. Symbol: <, the result was less than the stated value]

\begin{tabular}{lccccc}
\hline Site identifier & Date sampled & $\begin{array}{c}\text { Dissolved } \\
\text { thallium } \\
(\mu \mathbf{g} / \mathbf{L})\end{array}$ & $\begin{array}{c}\text { Dissolved } \\
\text { thallium, QA } \\
(\mu \mathbf{g} / \mathbf{L})\end{array}$ & Z-value & Remark \\
\hline ANP-9 & $10 / 14 / 94$ & $<0.5$ & $<0.5$ & 0 & \\
NRF-2 & $11 / 7 / 95$ & $<.5$ & $<.5$ & 0 & \\
NRF-3 & $6 / 8 / 95$ & $<.5$ & $<.5$ & 0 & \\
PSTF & $4 / 10 / 95$ & $<.5$ & .5 & 0 & \\
Tan Expl. & $4 / 12 / 94$ & $<.5$ & $<.5$ & 0 \\
USGS 7 & $4 / 6 / 95$ & $<.5$ & $<.5$ & 0 \\
USGS 17 & $11 / 7 / 95$ & $<.5$ & $<.5$ & 0 \\
USGS 26 & $4 / 11 / 95$ & $<.5$ & $<.5$ & 0 \\
USGS 98 & $6 / 12 / 95$ & $<.5$ & $<.5$ & 0 \\
USGS 102 & $9 / 13 / 95$ & $<.5$ & $<.5$ & \\
\hline
\end{tabular}


Table 37. Comparison of results of replicate pairs of samples from the Idaho National Engineering Laboratory analyzed for uranium

[Analyses by the National Water Quality Laboratory. Site identifier: see figures 1-3 for location of sites. Z-value: see section on statistical comparisons for explanation. Remark: no entry, analytical results of replicate pairs are statistically equivalent.

Abbreviations: QA, quality-assurance replicate sample; $\mu \mathrm{g} \Omega$, microgram per liter. Symbol: ${ }^{*}$, the $Q A$ sample was collected within 24 hours of the routine water-quality sample, rather than sequentially]

\begin{tabular}{lccccc}
\hline Site identifier & Date sampled & $\begin{array}{c}\text { Dissolved } \\
\text { uranium } \\
(\mu \mathrm{g} / \mathrm{L})\end{array}$ & $\begin{array}{c}\text { Dissolved } \\
\text { uranium, QA } \\
(\mu \mathrm{g} / \mathbf{L})\end{array}$ & Z-value & Remark \\
\hline ANP-9 & $10 / 14 / 94$ & 2 & 2 & 0.00 \\
PSTF & $4 / 10 / 95$ & 1 & 1 & .00 \\
USGS 7 & $4 / 06 / 95$ & 2 & 2 & .00 \\
USGS 26 & $4 / 11 / 95$ & 2 & 2 & .00 \\
USGS 84 & $10 / 18 / 95$ & 1 & $*_{1}$ & .00 \\
\hline
\end{tabular}


Table 38. Comparison of results of replicate pairs of samples from the Idaho National Engineering Laboratory analyzed for zinc

[Analyses by the National Water Quality Laboratory. Site identifier: see figures 1-3 for location of sites. Z-value: see section on statistical comparisons for explanation. Remark: no entry, analytical results of replicate pairs are statistically equivalent. Abbreviations: QA, quality-assurance replicate sample; $\mu \mathrm{g} / \mathrm{L}$, microgram per liter. Symbols: <, the result was less than the stated value; *, the QA sample was collected within 24 hours of the routine water-quality sample, rather than sequentially]

\begin{tabular}{|c|c|c|c|c|c|}
\hline Site identifier & Date sampled & $\begin{array}{c}\text { Zinc } \\
(\mu \mathbf{g} / \mathbf{L})\end{array}$ & $\begin{array}{c}\text { Zinc, QA } \\
(\mu \mathbf{g} / \mathbf{L})\end{array}$ & Z-value & Remark \\
\hline \multicolumn{6}{|c|}{ Dissolved } \\
\hline ANP-9 & $10 / 14 / 94$ & 12 & 11 & 0.14 & \\
\hline PSTF & $4 / 10 / 95$ & 2 & 6 & .61 & \\
\hline Tan Expl. & $4 / 12 / 94$ & $<1$ & $<1$ & .00 & \\
\hline USGS 7 & $4 / 6 / 95$ & 1 & $<1$ & .16 & \\
\hline USGS 26 & $4 / 11 / 95$ & 4 & 1 & .47 & \\
\hline USGS 84 & $10 / 18 / 95$ & 410 & *383 & .81 & \\
\hline \multicolumn{6}{|c|}{ Whole water, recoverable } \\
\hline NRF-2 & $11 / 7 / 95$ & $<10$ & 20 & .94 & \\
\hline NRF-3 & $6 / 8 / 95$ & $<10$ & 20 & .94 & \\
\hline NRF-6 & $3 / 10 / 95$ & $<10$ & $<10$ & .00 & \\
\hline USGS 17 & $11 / 7 / 95$ & $<10$ & $<10$ & .00 & \\
\hline USGS 98 & $6 / 12 / 95$ & 200 & 210 & .50 & \\
\hline USGS 102 & $9 / 13 / 95$ & $<10$ & $<10$ & .00 & \\
\hline
\end{tabular}


Table 39. Comparison of the results of replicate pairs of samples from the Idaho National Engineering Laboratory analyzed for gross alpha radioactivity by the National Water Quality Laboratory

[Site identifier: see figures 1-3 for location of sites. Z-value: see section on statistical comparisons for explanation. Remark: no entry; analytical results of replicate pairs are statistically equivalent; $N$, analytical results of replicate pairs are not statistically equivalent. Abbreviations: QA, quality-assurance replicate sample; $\mathrm{pCi} / \mathrm{L}$, picocurie per liter; $\mu \mathrm{g} / \mathrm{L}$, microgram per liter]

\begin{tabular}{|c|c|c|c|c|c|}
\hline Site identifier & Date sampled & $\begin{array}{c}\text { Dissolved gross alpha, } \\
\text { as thorium-230 } \\
(\mathrm{pCi} / \mathrm{L})\end{array}$ & $\begin{array}{c}\text { Dissolved gross alpha, } \\
\text { as thorium-230, } \mathrm{QA} \\
(\mathrm{pCi} / \mathrm{L})\end{array}$ & Z-value & Remark \\
\hline NRF-1 & $3 / 10 / 94$ & $3.48 \pm 1.75$ & $2.91 \pm 1.68$ & 0.47 & \\
\hline NRF-2 & $11 / 7 / 95$ & $3.77 \pm 1.84$ & $2.75 \pm 0.942$ & .99 & \\
\hline NRF-3 & $6 / 8 / 95$ & $9.08 \pm 4.08$ & $2.06 \pm 2.59$ & 2.91 & $\mathrm{~N}$ \\
\hline NRF-6 & $3 / 10 / 95$ & $2.94 \pm 7.22$ & $14.9 \pm 7.50$ & 2.30 & $\mathbf{N}$ \\
\hline NRF-7 & $6 / 13 / 94$ & $1.14 \pm 0.80$ & $1.88 \pm 1.06$ & 1.12 & \\
\hline WSINEL1 & $6 / 9 / 94$ & $1.84 \pm 1.51$ & $1.62 \pm 1.46$ & .21 & \\
\hline USGS 15 & $11 / 7 / 94$ & $4.55 \pm 2.38$ & $2.92 \pm 2.01$ & 1.05 & \\
\hline USGS 17 & $11 / 7 / 95$ & $1.66 \pm 0.956$ & $2.10 \pm 0.873$ & .68 & \\
\hline USGS 98 & $6 / 12 / 95$ & $2.18 \pm 2.03$ & $1.73 \pm 1.93$ & .32 & \\
\hline USGS 99 & $9 / 7 / 94$ & $2.59 \pm 1.15$ & $3.01 \pm 1.55$ & .39 & \\
\hline USGS 102 & $9 / 13 / 95$ & $2.19 \pm 1.36$ & $1.58 \pm 1.22$ & .67 & \\
\hline Site identifier & Date sampled & $\begin{array}{c}\text { Dissolved gross alpha, } \\
\text { as natural uranium } \\
(\mu \mathrm{g} / \mathrm{L})\end{array}$ & $\begin{array}{l}\text { Dissolved gross alpha, } \\
\text { as natural uranium, QA } \\
(\mu \mathrm{g} / \mathrm{L})\end{array}$ & $Z$-value & Remark \\
\hline NRF-1 & $3 / 10 / 94$ & $4.95 \pm 2.49$ & $4.54 \pm 2.61$ & .23 & \\
\hline NRF-2 & $11 / 7 / 95$ & $5.44 \pm 2.66$ & $5.37 \pm 3.00$ & .03 & \\
\hline NRF-3 & $6 / 8 / 95$ & $13.10 \pm 6.04$ & $3.40 \pm 4.29$ & 2.62 & $\mathrm{~N}$ \\
\hline NRF-6 & $3 / 10 / 95$ & $4.96 \pm 12.20$ & $24.10 \pm 12.40$ & 2.20 & $N$ \\
\hline NRF-7 & $6 / 13 / 94$ & $1.78 \pm 1.25$ & $2.43 \pm 1.38$ & .70 & \\
\hline WSINEL1 & $6 / 9 / 94$ & $2.62 \pm 2.15$ & $2.29 \pm 2.07$ & .22 & \\
\hline USGS 15 & $11 / 7 / 94$ & $6.70 \pm 3.52$ & $4.55 \pm 3.17$ & .91 & \\
\hline USGS 17 & $11 / 7 / 95$ & $2.34 \pm 1.35$ & $2.48 \pm 1.20$ & .16 & \\
\hline USGS 98 & $6 / 12 / 95$ & $3.50 \pm 3.28$ & $2.83 \pm 3.18$ & .29 & \\
\hline USGS 99 & $9 / 7 / 94$ & $3.50 \pm 2.04$ & $4.70 \pm 2.42$ & .34 & \\
\hline USGS 102 & $9 / 13 / 95$ & $3.10 \pm 1.93$ & $2.19 \pm 1.69$ & .71 & \\
\hline
\end{tabular}


Table 40. Comparison of the results of replicate pairs of samples from the Idaho National Engineering Laboratory analyzed for gross alpha radioactivity by the Radiological and Environmental Sciences Laboratory

[Samples were unfiltered and regarded as whole water, recoverable. Site identifier: see figures 1-3 for location of sites. Z-value: see section on statistical comparisons for explanation. Remark: no entry, analytical results of replicate pairs are statistically equivalent. Abbreviations: QA, quality-assurance replicate sample; pCi/L, picocurie per liter. Symbol: *, the QA sample was collected within 24 hours of the routine water-quality sample, rather than sequentially]

\begin{tabular}{|c|c|c|c|c|c|}
\hline Site identifier & Date sampled & $\begin{array}{l}\text { Gross alpha } \\
\text { (pCi/L) }\end{array}$ & $\begin{array}{c}\text { Gross alpha, QA } \\
(\text { (pCi/L) }\end{array}$ & $Z$-value & Remark \\
\hline ANP-9 & $10 / 14 / 94$ & $1.0 \pm 0.9$ & $2.8 \pm 1.2$ & 1.20 & \\
\hline ARBOR Test & $9 / 29 / 94$ & $-.3 \pm 0.7$ & $1.7 \pm 0.9$ & 1.75 & \\
\hline \multirow{2}{*}{ CFA LF2-10 } & $11 / 10 / 94$ & $.7 \pm 0.8$ & $2.8 \pm 1.2$ & 1.46 & \\
\hline & $10 / 25 / 95$ & $2.4 \pm 1.1$ & $1.4 \pm 0.9$ & .70 & \\
\hline Hwy 3 & $10 / 12 / 94$ & $1.4 \pm 0.9$ & $* 1.4 \pm 1.0$ & .00 & \\
\hline Leo Rogers & $7 / 18 / 94$ & $1.4 \pm 0.9$ & $2.8 \pm 1.2$ & .93 & \\
\hline NPR Test & $4 / 14 / 94$ & $2.8 \pm 1.2$ & $.7 \pm 0.8$ & 1.46 & \\
\hline PSTF & $4 / 10 / 95$ & $1.7 \pm 0.9$ & $1.4 \pm 0.9$ & .24 & \\
\hline Site 17 & $10 / 19 / 94$ & $2.4 \pm 1.1$ & $2.1 \pm 1.0$ & .20 & \\
\hline Tan Expl. & $4 / 12 / 94$ & $1.7 \pm 0.9$ & $1.0 \pm 0.9$ & .55 & \\
\hline USGS 4 & $4 / 19 / 95$ & $.7 \pm 0.8$ & $.7 \pm 0.8$ & .00 & \\
\hline USGS 7 & $4 / 6 / 95$ & $1.4 \pm 0.9$ & $1.4 \pm 0.9$ & .00 & \\
\hline USGS 11 & $10 / 26 / 95$ & $1.7 \pm 0.9$ & $1.4 \pm 0.9$ & .24 & \\
\hline USGS 17 & $10 / 27 / 94$ & $.7 \pm 1.0$ & $* 1.0 \pm 0.9$ & .22 & \\
\hline USGS 23 & $10 / 10 / 95$ & $1.4 \pm 0.9$ & $1.7 \pm 0.9$ & .24 & \\
\hline USGS 26 & $4 / 11 / 95$ & $1.0 \pm 0.9$ & $2.1 \pm 1.0$ & .82 & \\
\hline USGS 29 & $10 / 11 / 94$ & $.1 \pm 1.0$ & $.7 \pm 0.8$ & .47 & \\
\hline USGS 31 & $4 / 1 / 94$ & $1.4 \pm 0.9$ & $1.0 \pm 0.9$ & .31 & \\
\hline USGS 84 & $10 / 18 / 95$ & $2.1 \pm 1.0$ & $* 1.0 \pm 0.9$ & .82 & \\
\hline USGS 101 & $4 / 11 / 94$ & $2.1 \pm 1.0$ & $.3 \pm 0.8$ & 1.41 & \\
\hline USGS 105 & $3 / 31 / 94$ & $.7 \pm 0.8$ & $.3 \pm 0.8$ & .35 & \\
\hline USGS 108 & $4 / 18 / 95$ & $2.1 \pm 1.0$ & $1.0 \pm 0.9$ & .82 & \\
\hline USGS 120 & $10 / 23 / 95$ & $1.4 \pm 0.9$ & $1.4 \pm 0.9$ & .00 & \\
\hline USGS 121 & $10 / 24 / 94$ & $.7 \pm 0.8$ & $1.7 \pm 0.9$ & .83 & \\
\hline USGS 124 & $4 / 21 / 94$ & $1.4 \pm 0.9$ & $.7 \pm 0.8$ & .58 & \\
\hline USGS 125 & $6 / 16 / 95$ & $1.0 \pm 0.9$ & $1.4 \pm 0.9$ & .31 & \\
\hline
\end{tabular}


Table 41. Comparison of the results of replicate pairs of samples from the Idaho National Engineering Laboratory analyzed for gross beta radioactivity by the National Water Quality Laboratory

[Site identifier: see figures 1-3 for location of sites. Z-value: see section on statistical comparisons for explanation. Remark: no entr:, analytical results of replicate pairs are statistically equivalent; $N$, analytical results of replicate pairs are not statistically equivalent. Abbreviations: QA, quality-assurance replicate sample; $\mathrm{pCi} / \mathrm{L}$, picocurie per liter. Symbol: *, the QA sample was collected within 24 hours of the routine water-quality sample, rather than sequentially]

\begin{tabular}{|c|c|c|c|c|c|}
\hline Site identifier & Date sampled & $\begin{array}{l}\text { Dissolved gross beta, } \\
\text { as cesium-137 } \\
\text { (pCi/L) }\end{array}$ & $\begin{array}{c}\text { Dissolved gross beta, } \\
\text { as cesium-137, } \mathrm{QA} \\
(\mathrm{pCi} / \mathrm{L})\end{array}$ & Z-value & Remark \\
\hline NRF-1 & $3 / 10 / 94$ & $4.02 \pm 1.18$ & $3.63 \pm 1.06$ & 0.49 & \\
\hline NRF-2 & $11 / 7 / 95$ & $4.21 \pm 1.32$ & $4.71 \pm 1.56$ & .49 & \\
\hline NRF-3 & $6 / 8 / 95$ & $11.80 \pm 4.07$ & $2.46 \pm 4.59$ & 3.05 & $\mathrm{~N}$ \\
\hline NRF-6 & $3 / 16 / 95$ & $6.21 \pm 9.54$ & $12.30 \pm 7.55$ & 1.00 & \\
\hline NRF-7 & $6 / 13 / 94$ & $3.89 \pm 1.15$ & $3.38 \pm 1.08$ & .65 & \\
\hline WSINEL1 & $6 / 09 / 94$ & $3.65 \pm 1.16$ & $3.66 \pm 1.21$ & .01 & \\
\hline USGS 15 & $11 / 7 / 94$ & $1.89 \pm 1.84$ & $7.91 \pm 3.01$ & 3.41 & $\mathbf{N}$ \\
\hline USGS 17 & $11 / 7 / 95$ & $3.26 \pm 1.06$ & $3.50 \pm 1.07$ & .32 & \\
\hline USGS 98 & $6 / 12 / 95$ & $5.09 \pm 3.28$ & $2.75 \pm 3.07$ & 1.04 & \\
\hline USGS 99 & 9/7/94 & $2.81 \pm 0.97$ & $2.95 \pm 0.99$ & .20 & \\
\hline USGS 102 & 9/13/95 & $3.34 \pm 1.11$ & $4.08 \pm 1.21$ & .90 & \\
\hline Site identifier & Date sampled & $\begin{array}{c}\text { Dissolved gross beta, } \\
\text { as } \mathrm{Sr}-90 / \mathrm{Y}-90 \\
(\mathrm{pCi} / \mathrm{L})\end{array}$ & $\begin{array}{c}\text { Dissolved gross beta, } \\
\text { as } \mathrm{Sr}-90 / \mathrm{Y}-90, \mathrm{QA} \\
(\mathrm{pCi} / \mathrm{L})\end{array}$ & $Z$-value & . Remark \\
\hline NRF-1 & $3 / 10 / 94$ & $2.99 \pm 0.88$ & $2.73 \pm 0.80$ & .44 & \\
\hline NRF-2 & $11 / 7 / 95$ & $3.17 \pm 0.995$ & $3.43 \pm 1.48$ & .29 & \\
\hline NRF-3 & $6 / 8 / 95$ & $5.17 \pm 1.38$ & $1.65 \pm 3.07$ & 2.09 & $N$ \\
\hline NRF-6 & $3 / 16 / 95$ & $2.94 \pm 4.48$ & $5.97 \pm 3.44$ & 1.07 & \\
\hline NRF-7 & $6 / 13 / 94$ & $2.96 \pm 0.76$ & $2.60 \pm 0.73$ & .68 & \\
\hline WSINEL1 & $6 / 9 / 94$ & $2.76 \pm 0.88$ & $2.74 \pm 0.90$ & .03 & \\
\hline USGS 15 & $11 / 7 / 94$ & $1.50 \pm 1.46$ & $3.98 \pm 1.29$ & 2.55 & $\mathrm{~N}$ \\
\hline USGS 17 & $11 / 7 / 95$ & $2.50 \pm 0.693$ & $2.67 \pm 0.711$ & .34 & \\
\hline USGS 98 & $6 / 12 / 95$ & $3.47 \pm 2.16$ & $1.85 \pm 2.05$ & 1.09 & \\
\hline USGS 99 & $9 / 7 / 94$ & $2.12 \pm 0.73$ & $2.20 \pm 0.74$ & .15 & \\
\hline USGS 102 & $9 / 13 / 95$ & $2.53 \pm 0.839$ & $3.05 \pm 0.908$ & .84 & \\
\hline
\end{tabular}


Table 42. Comparison of the results of replicate pairs of samples from the Idaho National Engineering Laboratory analyzed for gross beta radioactivity by the Radiological and Environmental Sciences Laboratory

[Samples were unfiltered and regarded as whole water, recoverable.. Site identifier. see figures $1-3$ for location of sites. Z-value: see section on statistical comparisons for explanation. Remark: no entry, analytical results of replicate pairs are statistically equivalent. Abbreviations: QA, quality-assurance replicate sample; $\mathrm{pCi} / \mathrm{L}$, picocurie per liter. Symbols: *, the QA sample was collected within 24 hours of the routine water-quality sample, rather than sequentiallyl

\begin{tabular}{|c|c|c|c|c|c|}
\hline Site identifier & Date sampled & $\begin{array}{c}\text { Gross beta } \\
(\mathrm{pCi} / \mathrm{L})\end{array}$ & $\begin{array}{c}\text { Gross beta, QA } \\
(\mathrm{pCi} / \mathrm{L})\end{array}$ & $Z$-value & Remar"t \\
\hline ANP-9 & $10 / 14 / 94$ & $6 \pm 2$ & $5 \pm 2$ & 0.35 & \\
\hline ARBOR Test & $9 / 29 / 94$ & $4 \pm 2$ & $7 \pm 2$ & 1.06 & \\
\hline \multirow[t]{2}{*}{ CFA LF2-10 } & $11 / 10 / 94$ & $4 \pm 2$ & $4 \pm 2$ & .00 & \\
\hline & $10 / 25 / 95$ & $5 \pm 2$ & $4 \pm 2$ & .35 & \\
\hline Hwy 3 & $10 / 12 / 94$ & $2 \pm 2$ & $* 5 \pm 2$ & 1.06 & \\
\hline Leo Rogers & $7 / 18 / 94$ & $4 \pm 2$ & $5 \pm 2$ & .35 & \\
\hline NPR Test & $4 / 14 / 94$ & $3 \pm 2$ & $1.1 \pm 1.8$ & .71 & \\
\hline PSTF & $4 / 10 / 95$ & $4 \pm 2$ & $2 \pm 2$ & .71 & \\
\hline Site 17 & $10 / 19 / 94$ & $3 \pm 2$ & $* 3 \pm 2$ & .00 & \\
\hline Tan Expl. & $4 / 12 / 94$ & $3 \pm 2$ & $6 \pm 2$ & 1.06 & \\
\hline USGS 4 & $4 / 19 / 95$ & $6 \pm 2$ & $5 \pm 2$ & .35 & \\
\hline USGS 7 & $4 / 06 / 95$ & $1.3 \pm 1.9$ & $4 \pm 2$ & .98 & \\
\hline USGS 11 & $10 / 26 / 95$ & $5 \pm 2$ & $0 \pm 2$ & 1.77 & \\
\hline USGS 17 & $10 / 27 / 94$ & $2 \pm 2$ & $5 \pm 2$ & 1.06 & \\
\hline USGS 23 & $10 / 10 / 95$ & $3 \pm 2$ & $0 \pm 2$ & 1.06 & \\
\hline USGS 26 & $4 / 11 / 95$ & $2 \pm 2$ & $2 \pm 2$ & .00 & \\
\hline USGS 29 & $10 / 11 / 94$ & $4 \pm 2$ & $5 \pm 2$ & .35 & \\
\hline USGS 31 & $4 / 1 / 94$ & $6 \pm 2$ & $4 \pm 2$ & .71 & \\
\hline USGS 84 & $10 / 18 / 95$ & $5 \pm 2$ & $* 1.6 \pm 2.1$ & 1.17 & \\
\hline USGS 101 & $4 / 11 / 94$ & $3 \pm 2$ & $5 \pm 2$ & .71 & \\
\hline USGS 105 & $3 / 31 / 94$ & $4 \pm 2$ & $4 \pm 2$ & .00 & \\
\hline USGS 108 & $4 / 18 / 95$ & $3 \pm 2$ & $4 \pm 2$ & .35 & \\
\hline USGS 120 & $10 / 23 / 95$ & $6 \pm 2$ & $3 \pm 2$ & 1.06 & \\
\hline USGS 121 & $10 / 24 / 94$ & $3.0 \pm 1.4$ & $4 \pm 2$ & .41 & \\
\hline USGS 124 & $4 / 21 / 94$ & $5 \pm 2$ & $7 \pm 2$ & .71 & \\
\hline USGS 125 & $6 / 16 / 95$ & $6 \pm 2$ & $7 \pm 2$ & .35 & \\
\hline
\end{tabular}


Table 43. Comparison of the results of replicate pairs of samples from the Idaho National Engineering Laboratory analyzed for gamma radiation-Continued

[Analyses by the Radiological and Environmental Sciences Laboratory. Samples were unfiltered and regarded as whole water, recoverable. Site identifier: see figures $1-3$ for location of sites. Z-value: see section on statistical comparisons for explanation. Remark: no entry, analytical results of replicate pairs are statistically equivalent; $N$, analytical results of replicate pairs are not statistically equivalent. Abbreviations: $Q A$, quality-assurance replicate sample; $\mathrm{PCi} / \mathrm{L}$, picocurie per liter. Symbol: *, the $\mathrm{QA}$ sample was collected within $\mathbf{2 4}$ hours of the routine water-quality sample, rather than sequentially]

\begin{tabular}{|c|c|c|c|c|c|}
\hline Site identifier & Date sampled & $\begin{array}{c}\text { Gamma radiation } \\
(\mathrm{pCi} / \mathrm{L})\end{array}$ & $\begin{array}{c}\text { Gamma radiation, } Q A \\
(\mathrm{pCi} / \mathrm{L})\end{array}$ & Z-value & Remark \\
\hline ANP-9 & $10 / 14 / 94$ & $16 \pm 28$ & $20 \pm 20$ & 0.12 & \\
\hline ARBOR Test & $9 / 29 / 94$ & $60 \pm 20$ & $-20 \pm 30$ & 2.22 & $\mathbf{N}$ \\
\hline \multirow[t]{2}{*}{ CFA LF $2-10$} & $11 / 10 / 94$ & $0 \pm 20$ & $20 \pm 20$ & .71 & \\
\hline & $10 / 25 / 95$ & $20 \pm 30$ & $0 \pm 20$ & .71 & \\
\hline Hwy 3 & $10 / 12 / 94$ & $14 \pm 27$ & $* 30 \pm 20$ & .48 & \\
\hline Leo Rogers & $7 / 18 / 94$ & $12 \pm 13$ & $10 \pm 30$ & .06 & \\
\hline NPR Test & $4 / 14 / 94$ & $-10 \pm 30$ & $14 \pm 28$ & .58 & \\
\hline PSTF & $4 / 10 / 95$ & $-14 \pm 27$ & $30 \pm 40$ & .91 & \\
\hline Site 17 & $10 / 19 / 94$ & $30 \pm 20$ & $40 \pm 20$ & .35 & \\
\hline Tan Expl. & $4 / 12 / 94$ & $50 \pm 30$ & $-40 \pm 30$ & 2.12 & $\mathrm{~N}$ \\
\hline TRA A-13 & $10 / 4 / 95$ & $14 \pm 21$ & $-20 \pm 30$ & .93 & \\
\hline USGS 4 & $4 / 19 / 95$ & $-20 \pm 40$ & $-40 \pm 20$ & .45 & \\
\hline USGS 7 & $4 / 6 / 95$ & $0 \pm 30$ & $-10 \pm 40$ & .20 & \\
\hline USGS 11 & $10 / 26 / 95$ & $10 \pm 40$ & $16 \pm 36$ & .11 & \\
\hline USGS 17 & $10 / 27 / 94$ & $20 \pm 20$ & $* 20 \pm 30$ & .00 & \\
\hline USGS 23 & $10 / 10 / 95$ & $20 \pm 30$ & $-10 \pm 25$ & .77 & \\
\hline USGS 26 & $4 / 11 / 95$ & $7 \pm 16$ & $-10 \pm 30$ & .50 & \\
\hline USGS 29 & $10 / 11 / 94$ & $16 \pm 29$ & $-40 \pm 30$ & 1.34 & \\
\hline USGS 31 & $4 / 1 / 94$ & $0 \pm 30$ & $-15 \pm 27$ & .37 & \\
\hline USGS 40 & $1 / 13 / 94$ & $40 \pm 20$ & $30 \pm 30$ & .28 & \\
\hline USGS 44 & $10 / 16 / 95$ & $-20 \pm 20$ & $16 \pm 23$ & 1.18 & \\
\hline USGS 46 & $4 / 20 / 95$ & $0 \pm 20$ & $*-13 \pm 26$ & .40 & \\
\hline USGS 47 & $10 / 16 / 95$ & $-30 \pm 40$ & $0 \pm 20$ & .68 & \\
\hline USGS 50 & $4 / 13 / 95$ & $10 \pm 30$ & $-20 \pm 30$ & .71 & \\
\hline USGS 51 & $4 / 19 / 95$ & $-50 \pm 40$ & $0 \pm 20$ & 1.12 & \\
\hline USGS 58 & $4 / 11 / 95$ & $16 \pm 24$ & $20 \pm 30$ & .10 & \\
\hline USGS 61 & $4 / 28 / 94$ & $-14 \pm 29$ & $*-15 \pm 31$ & .02 & \\
\hline USGS 62 & $4 / 25 / 94$ & $30 \pm 20$ & $20 \pm 30$ & .28 & \\
\hline USGS 63 & $4 / 7 / 95$ & $-30 \pm 30$ & $20 \pm 30$ & 1.18 & \\
\hline USGS 65 & $1 / 12 / 94$ & $-12 \pm 16$ & $20 \pm 20$ & 1.25 & \\
\hline USGS 70 & $4 / 12 / 95$ & $-20 \pm 40$ & $0 \pm 20$ & .45 & \\
\hline USGS 84 & $10 / 18 / 95$ & $-80 \pm 40$ & $* 16 \pm 26$ & 2.01 & $\mathbf{N}$ \\
\hline USGS 87 & $1 / 11 / 95$ & $12 \pm 30$ & $* 11 \pm 27$ & .02 & \\
\hline USGS 101 & $4 / 11 / 94$ & $30 \pm 20$ & $15 \pm 29$ & .43 & \\
\hline
\end{tabular}


Table 43. Comparison of the results of replicate pairs of samples from the Idaho National Engineering Laboratory analyzed for gamma radiation-Continued

\begin{tabular}{|c|c|c|c|c|c|}
\hline Site identifier & Date sampled & $\begin{array}{c}\text { Gamma radiation } \\
(\mathrm{pC} \mathrm{C} / \mathrm{L})\end{array}$ & $\begin{array}{c}\text { Gamma radiation, } Q A \\
(\mathrm{pCi} / \mathrm{L})\end{array}$ & $Z$-value & Remark \\
\hline USGS 105 & $3 / 31 / 94$ & $30 \pm 30$ & $-16 \pm 29$ & 1.10 & \\
\hline USGS 108 & $4 / 18 / 95$ & $30 \pm 40$ & $-50 \pm 40$ & 1.41 & \\
\hline USGS 119 & $10 / 25 / 95$ & $0 \pm 40$ & $20 \pm 40$ & .45 & \\
\hline USGS 120 & $10 / 23 / 95$ & $0 \pm 20$ & $30 \pm 20$ & 1.06 & \\
\hline USGS 121 & $10 / 24 / 94$ & $10 \pm 20$ & $10 \pm 20$ & .00 & \\
\hline USGS 124 & $4 / 21 / 94$ & $10 \pm 30$ & $-20 \pm 30$ & .71 & \\
\hline USGS 125 & $6 / 16 / 95$ & $20 \pm 20$ & $50 \pm 40$ & .67 & \\
\hline
\end{tabular}


Table 44. Comparison of the results of replicate pairs of samples from the Idaho National Engineering Laboratory analyzed for strontium-90-Continued

[Analyses by the Radiological and Environmental Sciences Laboratory (RESL) and the National Water Quality Laboratory (NWQL). Samples for the RESL were unfiltered and regarded as whole water, recoverable. Site identifier: see figures 1-3 for location of sites. Z-value: see section on statistical comparisons for explanation. Remark: no entry, analytical results of replicate pairs are statisticall!" equivalent; $N$, analytical results of replicate pairs are not statistically equivalent. Abbreviations: $Q A$, quality-assurance replicate sample; pCi/L, picocurie per liter. Symbols: *, the QA sample was collected within 24 hours of the routine water-quality sample, rather than sequentially; \#\#, analysis of a filtered sample was performed by the NWQL and compared with the routine water-quality sample!

\begin{tabular}{|c|c|c|c|c|c|}
\hline Site identifier & Date sampled & $\begin{array}{l}\text { Strontium-90 } \\
(\mathrm{pCi} / \mathrm{L})\end{array}$ & $\begin{array}{c}\text { Strontium-90, QA } \\
(\mathrm{pCi} / \mathrm{L})\end{array}$ & Z-value & Remark \\
\hline ANP-9 & $10 / 14 / 94$ & $-1.4 \pm 1.7$ & $0 \pm 2$ & 0.53 & \\
\hline \multirow[t]{2}{*}{ CFA 1} & $4 / 7 / 94$ & $1.1 \pm 1.6$ & $.5 \pm 1.5$ & .27 & \\
\hline & $4 / 13 / 95$ & $.2 \pm 0.7$ & *. $6 \pm 0.7$ & .40 & \\
\hline CFA LF 2-10 & $11 / 10 / 94$ & $-1.3 \pm 1.8$ & $1 \pm 2$ & .85 & \\
\hline CFA LF 3-9 & $7 / 18 / 95$ & $2.6 \pm 0.7$ & $3.5 \pm 0.8$ & .85 & \\
\hline PSTF & $4 / 10 / 95$ & $.5 \pm 0.8$ & $.7 \pm 0.7$ & .19 & \\
\hline PW-4 & $1 / 14 / 94$ & $3 \pm 2$ & $* 2 \pm 2$ & .35 & \\
\hline PW-5 & $10 / 20 / 94$ & $6 \pm 2$ & $7 \pm 2$ & .35 & \\
\hline PW-6 & $1 / 24 / 94$ & $-1.1 \pm 1.9$ & $-4.0 \pm 1.6$ & 1.17 & \\
\hline PW-9 & $7 / 11 / 95$ & $2.7 \pm 0.8$ & $.13 \pm 0.76$ & 2.33 & $\mathbf{N}$ \\
\hline Tan Expl. & $4 / 2 / 94$ & $1 \pm 2$ & $-3 \pm 2$ & 1.41 & \\
\hline TRA A-13 & $10 / 4 / 95$ & $42 \pm 2$ & $39 \pm 2$ & 1.06 & \\
\hline USGS 2 & $7 / 13 / 95$ & $-.1 \pm 0.7$ & $.0 \pm 0.7$ & .10 & \\
\hline USGS 6 & $7 / 19 / 94$ & $0 \pm 2$ & $6 \pm 2$ & 2.12 & $\mathbf{N}$ \\
\hline USGS 7 & $4 / 6 / 95$ & $-.3 \pm 0.7$ & $.4 \pm 0.7$ & .71 & \\
\hline USGS 18 & $7 / 7 / 95$ & $0 \pm 0.8$ & $.3 \pm 0.7$ & .27 & \\
\hline USGS 26 & $4 / 11 / 95$ & $-2.1 \pm 0.9$ & $-.8 \pm 0.8$ & 1.08 & . \\
\hline \multirow[t]{2}{*}{ USGS 36} & $1 / 6 / 94$ & $14 \pm 2$ & $13 \pm 2$ & .35 & \\
\hline & $7 / 14 / 94$ & $11 \pm 2$ & $19 \pm 3$ & 2.22 & $\mathbf{N}$ \\
\hline \multirow[t]{3}{*}{ USGS 39} & $4 / 25 / 94$ & $-2 \pm 2$ & $2 \pm 1.7$ & 1.52 & \\
\hline & $1 / 20 / 95$ & $-1.0 \pm 0.4$ & $-.5 \pm 0.7$ & .62 & \\
\hline & $7 / 3 / 95$ & $1.4 \pm 0.8$ & $1.6 \pm 0.7$ & .19 & \\
\hline USGS 40 & $1 / 13 / 94$ & $19 \pm 3$ & $30 \pm 3$ & 2.59 & $\mathbf{N}$ \\
\hline USGS 41 & $5 / 3 / 94$ & $17 \pm 3$ & $23 \pm 3$ & 1.41 & \\
\hline USGS 42 & $10 / 18 / 94$ & $10 \pm 2$ & $9 \pm 3$ & .28 & \\
\hline USGS 44 & $10 / 16 / 95$ & $6.6 \pm 0.9$ & $7.2 \pm 0.9$ & .47 & \\
\hline \multirow[t]{2}{*}{ USGS 45} & $4 / 13 / 95$ & $4.1 \pm 0.8$ & $4.3 \pm 0.8$ & .18 & \\
\hline & $10 / 11 / 95$ & $1.6 \pm 0.9$ & $12 \pm 2$ & 4.74 & $\mathbf{N}$ \\
\hline USGS 46 & $4 / 20 / 95$ & $14.6 \pm 1.1$ & $* 14.1 \pm 1.1$ & .32 & \\
\hline USGS 47 & $10 / 16 / 95$ & $76 \pm 3$ & $47 \pm 2$ & 8.04 & $\mathbf{N}$ \\
\hline USGS 48 & $4 / 22 / 94$ & $17 \pm 2$ & $18 \pm 2$ & .35 & \\
\hline USGS 50 & $4 / 13 / 95$ & $164 \pm 5$ & $178 \pm 6$ & 1.79 & \\
\hline USGS 51 & $4 / 21 / 94$ & $-1.9 \pm 1.6$ & $.6 \pm 1.6$ & 1.10 & \\
\hline
\end{tabular}


Table 44. Comparison of the results of replicate pairs of samples from the Idaho National Engineering Laboratory analyzed for strontium-90-Continued

\begin{tabular}{|c|c|c|c|c|c|}
\hline Site identifier & Date sampled & $\begin{array}{l}\text { Strontium-90 } \\
\quad(\mathrm{pCi} / \mathrm{L})\end{array}$ & $\begin{array}{c}\text { Strontium-90, QA } \\
\quad(\mathrm{pCi} / \mathrm{L})\end{array}$ & $Z$-value & Remarl \\
\hline USGS 51-cont. & $9 / 19 / 95$ & $0.6 \pm 0.7$ & $-0.5 \pm 0.6$ & 1.19 & \\
\hline USGS 53 & $10 / 25 / 94$ & $120 \pm 6$ & $117 \pm 6$ & .35 & \\
\hline \multirow[t]{2}{*}{ USGS 55} & $10 / 25 / 94$ & $10 \pm 2$ & $8 \pm 2$ & 0.71 & \\
\hline & $10 / 4 / 95$ & $6.4 \pm 0.9$ & $8.8 \pm 1.0$ & 1.78 & \\
\hline USGS 58 & $4 / 11 / 95$ & $-1.2 \pm 0.7$ & $-1.6 \pm 0.8$ & .38 & \\
\hline USGS 59 & $10 / 23 / 95$ & $16.2 \pm 1.1$ & $24 \pm 2$ & 3.42 & $\mathrm{~N}$ \\
\hline USGS 61 & $4 / 28 / 94$ & $1.6 \pm 2.2$ & $* 0 \pm 2$ & .54 & \\
\hline USGS 62 & $4 / 25 / 94$ & $4 \pm 2$ & $2 \pm 2$ & .71 & \\
\hline USGS 63 & $4 / 7 / 95$ & $7.9 \pm .9$ & $8.4 \pm 1.0$ & .37 & \\
\hline USGS 65 & $1 / 12 / 94$ & $-3 \pm 2$ & $-2 \pm 2$ & .35 & \\
\hline \multirow[t]{2}{*}{ USGS 67} & $4 / 12 / 95$ & $13.8 \pm 1.1$ & $16.0 \pm 1.1$ & 1.41 & \\
\hline & $10 / 17 / 95$ & $13.7 \pm 1.1$ & $1 \pm 2$ & 5.56 & $\mathrm{~N}$ \\
\hline \multirow[t]{2}{*}{ USGS 69} & $7 / 11 / 94$ & $1 \pm 2$ & $6 \pm 2$ & 1.77 & \\
\hline & $7 / 6 / 95$ & $.3 \pm 0.8$ & $* .2 \pm 0.7$ & .09 & \\
\hline \multirow[t]{2}{*}{ USGS 70} & $10 / 27 / 94$ & $61 \pm 4$ & $65 \pm 4$ & .71 & \\
\hline & $4 / 12 / 95$ & $55 \pm 2$ & $57 \pm 3$ & .55 & \\
\hline USGS 78 & $7 / 13 / 95$ & $.9 \pm 0.8$ & $2.5 \pm 0.8$ & 1.41 & \\
\hline USGS 84 & $10 / 18 / 95$ & $-.13 \pm 0.76$ & $*_{-.12 \pm 0.76}$ & .01 & \\
\hline \multirow[t]{2}{*}{ USGS 87} & $1 / 11 / 95$ & $.3 \pm 0.9$ & $2.7 \pm 0.8$ & 1.99 & $N$ \\
\hline & & & $\#-.089 \pm 0.25$ & .42 & \\
\hline USGS 111 & $4 / 18 / 94$ & $-1.0 \pm 1.6$ & $.3 \pm 1.6$ & .57 & \\
\hline \multirow[t]{2}{*}{ USGS 112} & $1 / 13 / 94$ & $25 \pm 3$ & $* 23 \pm 3$ & .47 & \\
\hline & 10/13/94 & $28 \pm 3$ & $26 \pm 6$ & .30 & \\
\hline USGS 113 & $7 / 13 / 94$ & $17 \pm 3$ & $* 19 \pm 3$ & .47 & \\
\hline USGS 115 & $7 / 6 / 95$ & $-1.2 \pm .8$ & $* .1 \pm 1.6$ & .73 & \\
\hline \multirow[t]{2}{*}{ USGS 116} & $2 / 1 / 95$ & $.7 \pm 0.9$ & $-.1 \pm 0.8$ & .66 & \\
\hline & $10 / 17 / 95$ & $.5 \pm 0.7$ & $*_{-.1 \pm 1.4}$ & .38 & \\
\hline USGS 119 & $10 / 25 / 95$ & $-.9 \pm 0.7$ & $-.4 \pm 0.7$ & .51 & \\
\hline USGS 120 & $10 / 23 / 95$ & $-.7 \pm 0.8$ & $2.5 \pm 0.8$ & 2.83 & $N$ \\
\hline USGS 121 & $10 / 24 / 94$ & $.6 \pm 1.6$ & $2 \pm 2$ & .55 & \\
\hline \multirow[t]{2}{*}{ USGS 123} & $10 / 31 / 94$ & $37 \pm 3$ & $36 \pm 3$ & .24 & \\
\hline & $10 / 30 / 95$ & $34.2 \pm 1.6$ & $74 \pm 4$ & 9.24 & $N$ \\
\hline USGS 124 & $4 / 21 / 94$ & $1 \pm 2$ & $.6 \pm 1.6$ & .16 & \\
\hline
\end{tabular}


Table 45. Comparison of the results of replicate pairs of samples from the Idaho National Engineering Laboratory analyzed for tritium-Continued

[Analyses by the Radiological and Environmental Sciences Laboratory (RESL) and the National Water Quality Laboratory (NWQL). Samples for the RESL were unfiltered and regarded as whole water, recoverable (WWR). Site identifier: see figures $1-3$ for location of sites. Z-value: see section on statistical comparisons for explanation. Remark: no entry, analytical results of replicate pairs are statistically equivalent. Abbreviations: QA, quality-assurance replicate sample; $p C i / L$, picocurie per liter. Symbols: *, the QA sample was collected within 24 hours of the routine water-quality sample, rather than sequentially; ${ }^{\# \#}$, analysis was performed by the NWQL. for WWR tritium]

\begin{tabular}{|c|c|c|c|c|c|}
\hline Site identifier & Date sampled & $\begin{array}{l}\text { Tritium } \\
\text { (pCi/L) }\end{array}$ & $\begin{array}{l}\text { Tritium, QA } \\
\text { (pCi/L) }\end{array}$ & Z-value & Remark \\
\hline ANP-9 & $10 / 14 / 94$ & $-200 \pm 200$ & $-270 \pm 170$ & 0.27 & \\
\hline ARBOR Test & $9 / 29 / 94$ & $-120 \pm 170$ & $-250 \pm 170$ & .54 & \\
\hline Atomic City & $4 / 6 / 94$ & $-170 \pm 80$ & $-240 \pm 80$ & .62 & \\
\hline \multirow[t]{3}{*}{ CFA 1} & $4 / 7 / 94$ & $14,300 \pm 600$ & $14,000 \pm 600$ & .35 & \\
\hline & $1 / 5 / 95$ & $18,100 \pm 800$ & $18,200 \pm 800$ & .09 & \\
\hline & $4 / 13 / 95$ & $13,700 \pm 600$ & $* 13,400 \pm 600$ & .35 & \\
\hline \multirow[t]{2}{*}{ CFA LF 2-10 } & $11 / 10 / 94$ & $6,500 \pm 400$ & $6,700 \pm 400$ & .35 & \\
\hline & $10 / 25 / 95$ & $6,100 \pm 400$ & $6,000 \pm 400$ & .18 & \\
\hline CFA LF 3-9 & $7 / 18 / 95$ & $24,100 \pm 1,000$ & $23,700 \pm 900$ & .30 & \\
\hline Hwy 3 & $10 / 12 / 94$ & $0 \pm 200$ & $*-100 \pm 200$ & .35 & \\
\hline Leo Rogers & $7 / 18 / 94$ & $100 \pm 200$ & $-60 \pm 170$ & .61 & \\
\hline MTR Test & $4 / 26 / 95$ & $1,600 \pm 200$ & $1,900 \pm 200$ & 1.06 & \\
\hline NPR Test & $4 / 14 / 94$ & $-250 \pm 170$ & $-220 \pm 170$ & .12 & \\
\hline NRF-2 & $11 / 7 / 95$ & $\# 64.0 \pm 25.6$ & $\#-1.2 \pm 25.6$ & .35 & \\
\hline NRF-3 & $6 / 8 / 95$ & $\#$ \#4.0土25.6 & $\# 92.8 \pm 25.6$ & 1.59 & \\
\hline NRF-6 & $3 / 10 / 95$ & $\#^{\#} 124.8 \pm 25.6$ & $80 \pm 32$ & 1.09 & \\
\hline PSTF & $4 / 10 / 95$ & $-70 \pm 170$ & $-80 \pm 170$ & .04 & \\
\hline PW-4 & $1 / 14 / 94$ & $1,100 \pm 200$ & $* 1,100 \pm 200$ & .00 & \\
\hline PW-5 & $10 / 20 / 94$ & $400 \pm 200$ & $400 \pm 200$ & .00 & \\
\hline PW-6 & $1 / 24 / 94$ & $21,500 \pm 900$ & $22,200 \pm 900$ & .55 & \\
\hline PW-9 & $7 / 11 / 95$ & $162,000 \pm 5,000$ & $160,000 \pm 5,000$ & .28 & \\
\hline Site 4 & $4 / 13 / 95$ & $0 \pm 200$ & $-60 \pm 170$ & .23 & \\
\hline Site 17 & $10 / 19 / 94$ & $-140 \pm 170$ & $* 0 \pm 200$ & .53 & \\
\hline Tan Expl. & $4 / 12 / 94$ & $-240 \pm 170$ & $-290 \pm 170$ & .21 & \\
\hline TRA A-13 & $10 / 4 / 95$ & 100200 & 0200 & .35 & \\
\hline USGS 2 & $7 / 13 / 95$ & $-70 \pm 170$ & $-140 \pm 160$ & .30 & \\
\hline USGS 4 & $4 / 19 / 95$ & $-50 \pm 170$ & $0 \pm 200$ & .19 & \\
\hline USGS 6 & $7 / 19 / 94$ & $100 \pm 200$ & $-120 \pm 160$ & .86 & \\
\hline USGS 7 & $4 / 6 / 95$ & $-130 \pm 170$ & $-140 \pm 170$ & .04 & \\
\hline USGS 11 & $10 / 26 / 95$ & $-11 \pm 70$ & $20 \pm 70$ & .31 & \\
\hline \multirow[t]{2}{*}{ USGS 17} & $10 / 28 / 94$ & $\#$ \#7.6土25.6 & $*_{-1} 100 \pm 200$ & .78 & \\
\hline & $11 / 7 / 95$ & $\# 38.4 \pm 25.6$ & 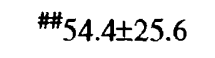 & .44 & \\
\hline USGS 18 & $7 / / 95$ & $-160 \pm 170$ & $-70 \pm 170$ & .37 & \\
\hline
\end{tabular}


Table 45. Comparison of the results of replicate pairs of samples from the Idaho National Engineering Laboratory analyzed for tritium-Continued

\begin{tabular}{|c|c|c|c|c|c|}
\hline Site identifier & Date sampled & $\begin{array}{l}\text { Tritium } \\
(\mathbf{p C i} / \mathbf{L})\end{array}$ & $\begin{array}{l}\text { Tritium, QA } \\
(\mathbf{p C i} / \mathbf{L})\end{array}$ & Z-value & Rema-k \\
\hline USGS 23 & $10 / 10 / / 95$ & $-130 \pm 170$ & $0 \pm 200$ & 0.50 & \\
\hline USGS 26 & $4 / 11 / 95$ & $-130 \pm 170$ & $-140 \pm 170$ & .04 & \\
\hline USGS 29 & $10 / 11 / 94$ & $-100 \pm 200$ & $-100 \pm 200$ & .00 & \\
\hline USGS 31 & $4 / 1 / 94$ & $-100 \pm 200$ & $-200 \pm 200$ & .35 & \\
\hline \multirow[t]{2}{*}{ USGS 36} & $1 / 6 / 94$ & $9,700 \pm 500$ & $10,300 \pm 500$ & .85 & \\
\hline & $7 / 14 / 94$ & $9,300 \pm 500$ & $9,700 \pm 500$ & .57 & \\
\hline \multirow[t]{3}{*}{ USGS 39} & $4 / 25 / 94$ & $6,000 \pm 400$ & $5,800 \pm 400$ & .35 & \\
\hline & $1 / 20 / 95$ & $6,200 \pm 400$ & $6,100 \pm 400$ & .18 & \\
\hline & $7 / 3 / 95$ & $5,800 \pm 400$ & $5,800 \pm 400$ & .00 & \\
\hline USGS 40 & $1 / 13 / 94$ & $6,800 \pm 400$ & $6,900 \pm 400$ & .18 & \\
\hline USGS 41 & $5 / 3 / 94$ & $4,400 \pm 300$ & $4,300 \pm 300$ & .24 & \\
\hline USGS 42 & $10 / 18 / 94$ & $2,200 \pm 200$ & $2,200 \pm 200$ & .00 & \\
\hline USGS 44 & $10 / 16 / 95$ & $600 \pm 200$ & $500 \pm 200$ & .35 & \\
\hline \multirow[t]{2}{*}{ USGS 45} & $4 / 13 / 95$ & $2,000 \pm 200$ & $1,800 \pm 200$ & .71 & \\
\hline & $10 / 11 / 95$ & $2,300 \pm 200$ & $2,300 \pm 200$ & .00 & \\
\hline USGS 46 & $4 / 20 / 95$ & $3,200 \pm 300$ & $* 3,300 \pm 300$ & .24 & \\
\hline USGS 47 & $10 / 16 / 95$ & $7,600 \pm 400$ & $7,600 \pm 400$ & .00 & \\
\hline USGS 48 & $4 / 22 / 94$ & $4,400 \pm 300$ & $4,200 \pm 300$ & .47 & \\
\hline USGS 50 & $4 / 13 / 95$ & $58,400 \pm 2,100$ & $58,200 \pm 2,100$ & .07 & \\
\hline \multirow[t]{2}{*}{ USGS 51} & $4 / 21 / 94$ & $23,100 \pm 900$ & $22,500 \pm 900$ & .47 & \\
\hline & $4 / 19 / 95$ & $20,100 \pm 800$ & $20,900 \pm 800$ & .71 & \\
\hline USGS 53 & $10 / 25 / 94$ & $122,000 \pm 4,000$ & $122,000 \pm 4,000$ & .00 & \\
\hline \multirow[t]{2}{*}{ USGS 55} & $10 / 25 / 94$ & $900 \pm 200$ & $1,000 \pm 200$ & .35 & \\
\hline & $10 / 4 / 95$ & $1,600 \pm 200$ & $1,300 \pm 200$ & 1.06 & \\
\hline USGS 58 & $4 / 11 / 95$ & $4,600 \pm 300$ & $4,100 \pm 300$ & 1.18 & \\
\hline USGS 59 & $10 / 23 / 95$ & $13,000 \pm 600$ & $13,600 \pm 600$ & .71 & \\
\hline USGS 61 & $4 / 28 / 94$ & $36,700 \pm 1,400$ & $* 37,500 \pm 1,400$ & .40 & \\
\hline USGS 62 & $4 / 25 / 94$ & $1,500 \pm 200$ & $1,200 \pm 200$ & 1.06 & \\
\hline USGS 63 & $4 / 7 / 95$ & $600 \pm 200$ & $400 \pm 200$ & .71 & \\
\hline USGS 65 & $1 / 12 / 94$ & $26,800 \pm 1,000$ & $26,500 \pm 1,000$ & .21 & \\
\hline \multirow[t]{2}{*}{ USGS 67} & $4 / 12 / 95$ & $18,600 \pm 800$ & $18,400 \pm 800$ & .18 & \\
\hline & $10 / 16795$ & $16,800 \pm 700$ & $16,400 \pm 700$ & .40 & \\
\hline \multirow[t]{2}{*}{ USGS 69} & $7 / 11 / 94$ & $-100 \pm 160$ & $100 \pm 200$ & .78 & \\
\hline & $7 / 6 / 95$ & $-20 \pm 170$ & $* 0 \pm 200$ & .08 & \\
\hline \multirow[t]{2}{*}{ USGS 70} & $10 / 2794$ & $29,100 \pm 1,100$ & $28,000 \pm 1,100$ & .71 & \\
\hline & $4 / 12 / 95$ & $33,900 \pm 1,300$ & $35,800 \pm 1,300$ & 1.03 & \\
\hline USGS 78 & $7 / 13 / 95$ & $-60 \pm 170$ & $-100 \pm 170$ & .17 & \\
\hline USGS 79 & $4 / 15 / 94$ & $-110 \pm 170$ & $*-160 \pm 170$ & .21 & \\
\hline
\end{tabular}


Table 45. Comparison of the results of replicate pairs of samples from the Idaho National Engineering Laboratory analyzed for tritium-Continued

\begin{tabular}{|c|c|c|c|c|c|}
\hline Site identifier & Date sampled & $\begin{array}{l}\text { Tritium } \\
(\mathrm{pCi} / \mathrm{L})\end{array}$ & $\begin{array}{l}\text { Tritium, QA } \\
(\mathrm{pCi} / \mathrm{L})\end{array}$ & $Z$-value & Remark \\
\hline USGS 84 & $10 / 18 / 95$ & $1,600 \pm 200$ & $* 1,900 \pm 200$ & 1.06 & \\
\hline USGS 87 & $1 / 11 / 95$ & $1,000 \pm 200$ & $* 1,100 \pm 200$ & .35 & \\
\hline USGS 98 & $6 / 12 / 95$ & $\# 9.6 \pm 25.6$ & $\# 22.4 \pm 25.6$ & .35 & \\
\hline USGS 100 & $10 / 19 / 95$ & $-100 \pm 200$ & $-100 \pm 200$ & .00 & \\
\hline USGS 101 & $4 / 11 / 94$ & $-300 \pm 170$ & $-330 \pm 160$ & .13 & \\
\hline USGS 102 & $9 / 13 / 95$ & $\# 35.2 \pm 25.6$ & $\#$ \#7.6土25.6 & .62 & \\
\hline USGS 105 & $3 / 31 / 94$ & $100 \pm 80$ & $30 \pm 80$ & .62 & \\
\hline USGS 108 & $4 / 18 / 95$ & $-140 \pm 70$ & $-110 \pm 80$ & .28 & \\
\hline USGS 111 & $4 / 18 / 94$ & $12,600 \pm 600$ & $12,700 \pm 600$ & .12 & \\
\hline \multirow[t]{2}{*}{ USGS 112} & $1 / 13 / 94$ & $16,000 \pm 700$ & $* 15,600 \pm 700$ & .40 & \\
\hline & $10 / 13 / 94$ & $14,800 \pm 700$ & $14,700 \pm 700$ & .06 & \\
\hline USGS 113 & $7 / 13 / 94$ & $122,000 \pm 6,000$ & $* 119,000 \pm 6,000$ & .35 & \\
\hline USGS 115 & $7 / 6 / 95$ & $4,500 \pm 300$ & $* 4,500 \pm 300$ & .00 & \\
\hline \multirow[t]{2}{*}{ USGS 116} & $2 / 1 / 95$ & $8,600 \pm 500$ & $9,000 \pm 500$ & .57 & \\
\hline & $10 / 17 / 95$ & $4,100 \pm 300$ & $* 4,300 \pm 300$ & .47 & \\
\hline USGS 119 & $10 / 25 / 95$ & $-100 \pm 200$ & $-160 \pm 170$ & .23 & \\
\hline USGS 120 & $10 / 23 / 95$ & $100 \pm 180$ & $100 \pm 200$ & .00 & \\
\hline USGS 121 & $10 / 23 / 94$ & $0 \pm 200$ & $-200 \pm 200$ & .71 & \\
\hline \multirow[t]{2}{*}{ USGS 123} & $10 / 31 / 94$ & $26,400 \pm 1,000$ & $25,300 \pm 1,000$ & .78 & \\
\hline & $10 / 30 / 95$ & $20,500 \pm 800$ & $20,700 \pm 800$ & .18 & \\
\hline USGS 124 & $4 / 21 / 94$ & $-140 \pm 79$ & $30 \pm 80$ & 1.51 & \\
\hline USGS 125 & $6 / 16 / 95$ & $30 \pm 70$ & $40 \pm 70$ & .10 & \\
\hline
\end{tabular}


Table 46. Comparison of the result of replicate pairs of samples from the Idaho National Engineering Laboratory analyzed for transuranics (americium-241, plutonium-238, and plutonium-239/240)

[Analyses by the Radiological and Environmental Sciences Laboratory. Samples were unfiltered and regarded as whole water, recoverable. Site identifier: see figures $1-3$ for location of sites. Z-value: see section on statistical comparisons for explanation. Remark: no entry, analytical results of replicate pairs are statistically equivalent. Abbreviations: QA, quality-assurance replicate sample; $\mathrm{pCi} / \mathrm{L}$, picocurie per liter. Symbol: *, the QA sample was collected within 24 hours of the routine water-quality sample, rather than sequentially]

\begin{tabular}{|c|c|c|c|c|c|}
\hline Site identifier & Date sampled & $\begin{array}{l}\text { Americium-241 } \\
(\mathrm{pCi} / \mathrm{L})\end{array}$ & $\begin{array}{c}\text { Americium-241, } \mathrm{Q \Lambda} \\
(\mathrm{pCi} / \mathrm{L})\end{array}$ & $Z$-value & Remark \\
\hline USGS 40 & $1 / 13 / 94$ & $0.02 \pm 0.02$ & $0.013 \pm 0.019$ & 0.25 & \\
\hline USGS 47 & $10 / 16 / 95$ & $.03 \pm 0.02$ & $.(x) \pm 0 .(1)$ & 1.06 & \\
\hline USGS 84 & $10 / 18 / 95$ & $.00 \pm 0 .(12$ & $* .01 \pm 0.02$ & .35 & \\
\hline USGS 87 & $1 / 11 / 95$ & $.00 \pm 0.02$ & $* .010 \pm 0.020$ & .35 & \\
\hline USGS 119 & $10 / 25 / 95$ & $.010 \pm 0.018$ & $.017 \pm 0.018$ & .27 & \\
\hline USGS 120 & $10 / 23 / 95$ & $.010 \pm 0.018$ & $.01 \pm 0.02$ & .00 & \\
\hline USGS 121 & $10 / 24 / 94$ & $-.02 \pm 0.02$ & $.00 \pm 0.02$ & .71 & \\
\hline Site identifier & Date sampled & $\begin{array}{l}\text { Plutonium-238 } \\
(\mathrm{pCi} / \mathrm{L})\end{array}$ & $\begin{array}{c}\text { Plutonium-238, } Q \Lambda \\
(p(\mathrm{i} / \mathrm{L})\end{array}$ & $\mathbf{Z}$-value & Remrrk \\
\hline USGS 40 & $1 / 13 / 94$ & $.022 \pm 0.016$ & $.010 \pm 0.016$ & .53 & \\
\hline USGS 47 & $10 / 16 / 95$ & $.003 \pm 0.015$ & $.008 \pm 0.014$ & .24 & \\
\hline USGS 84 & $10 / 18 / 95$ & $.01 \pm 0.02$ & $* .001 \pm 0.014$ & .37 & \\
\hline USGS 87 & $1 / 11 / 95$ & $-.008 \pm 0.015$ & $*_{-.019 \pm 0.014}$ & .54 & \\
\hline USGS 119 & $10 / 25 / 95$ & $.017 \pm 0.017$ & $-.016 \pm 0.014$ & 1.50 & \\
\hline USGS 120 & $10 / 23 / 95$ & $-.012 \pm 0.02$ & $-.007 \pm 0.013$ & .23 & \\
\hline USGS 121 & $10 / 24 / 94$ & $.02 \pm 0.02$ & $.003 \pm 0.014$ & .70 & \\
\hline Site identifier & Date sampled & $\begin{array}{c}\text { Plutonium-239/240 } \\
(\mathrm{pCi} / \mathrm{L})\end{array}$ & $\begin{array}{c}\text { Plutonium-239/240, QA } \\
(\mathrm{pCi} / \mathrm{L})\end{array}$ & $Z$-value & Remark \\
\hline USGS 40) & $1 / 13 / 94$ & $.003 \pm 0.011$ & $.010 \pm 0.013$ & .41 & \\
\hline USGS 47 & $10 / 16 / 95$ & $.008 \pm 0.014$ & $-.015 \pm 0.013$ & .34 & \\
\hline USGS 84 & $10 / 18 / 95$ & $.01 \pm 0.02$ & $* .002 \pm 0.014$ & .33 & \\
\hline USGS 87 & $1 / 11 / 95$ & $-.009 \pm 0.015$ & $*_{-.}(009 \pm 0.014$ & .00 & \\
\hline USGS 119 & $10 / 25 / 95$ & $.001 \pm 0.014$ & $-.015 \pm 0.014$ & .81 & \\
\hline USGS 120 & $10 / 23 / 95$ & $.002 \pm 0.016$ & $.0(2) \pm 0.014$ & .09 & \\
\hline USGS 121 & $10 / 24 / 94$ & $-.007 \pm 0.012$ & $-.019 \pm 0.015$ & .62 & \\
\hline
\end{tabular}


Table 47. Comparison of results of replicate pairs of samples from the Idaho National Engineering Laboraton' analyzed for total organic carbon

[Analyses by the National Water Quality Laboratory. Site identifier: see figures $1-3$ for location of sites. Z-value: see section on statistical comparisons for explanation. Remark: no entry, analytical results of replicate pairs are statistically equivalent; $\mathrm{N}$, analytica' results of replicate pairs are not statistically equivalent. Abbreviations: QA, quality-assurance replicate sample; mg/L, milligram per liter. Symbols: *, the QA sample was collected within 24 hours of the routine water-quality sample, rather than sequentially]

\begin{tabular}{|c|c|c|c|c|c|}
\hline Site identifier & Date sampled & $\begin{array}{l}\text { Total organic } \\
\text { carbon } \\
(\mathbf{m g} / \mathrm{L})\end{array}$ & $\begin{array}{c}\text { Total organic } \\
\text { carbon, QA } \\
(\mathrm{mg} / \mathrm{L})\end{array}$ & Z-value & Remark \\
\hline ANP-9 & $10 / 14 / 94$ & 0.4 & 0.8 & 1.94 & \\
\hline ARBOR Test & 9/29/94 & .8 & .4 & 1.94 & \\
\hline \multirow[t]{2}{*}{ CFA LF 2-10 } & $11 / 10 / 94$ & .2 & .4 & .96 & \\
\hline & $10 / 25 / 95$ & 5.6 & .2 & 27.21 & N \\
\hline Hwy 3 & $10 / 12 / 94$ & .9 & $* .6$ & 1.46 & \\
\hline NRF-1 & $3 / 10 / 94$ & .9 & .4 & 2.24 & $\mathrm{~N}$ \\
\hline NRF-2 & $11 / 7 / 95$ & 1.5 & .4 & 5.37 & $\mathrm{~N}$ \\
\hline NRF-3 & 6/8/95 & 3.2 & 3.4 & 1.03 & \\
\hline NRF-6 & $3 / 10 / 95$ & .2 & 2.1 & 9.31 & $\mathrm{~N}$ \\
\hline NRF-7 & $6 / 13 / 94$ & .1 & .2 & .48 & \\
\hline Site 17 & $10 / 19 / 94$ & .5 & 1.4 & 4.39 & $\mathrm{~N}$ \\
\hline WSINEL1 & 6/9/94 & .7 & .5 & 0.97 & \\
\hline USGS 11 & $10 / 26 / 95$ & .2 & .5 & 1.45 & \\
\hline USGS 15 & $11 / 7 / 94$ & .2 & .2 & .00 & \\
\hline \multirow[t]{2}{*}{ USGS 17} & $10 / 28 / 94$ & .7 & $* .7$ & .00 & \\
\hline & $11 / 7 / 95$ & 1.0 & .2 & 3.88 & $\mathbf{N}$ \\
\hline USGS 23 & $10 / 10 / 95$ & .1 & .1 & .00 & \\
\hline USGS 29 & $10 / 11 / 94$ & .6 & .7 & .48 & \\
\hline USGS 84 & $10 / 18 / 95$ & .2 & $* 1.8$ & 7.82 & $\mathrm{~N}$ \\
\hline USGS 98 & $6 / 12 / 95$ & .3 & .2 & .48 & \\
\hline USGS 99 & $9 / 7 / 94$ & 1.2 & .6 & 2.92 & $\mathrm{~N}$ \\
\hline USGS 102 & $9 / 13 / 95$ & 4.6 & 6.1 & 8.07 & $\mathbf{N}$ \\
\hline USGS 120 & $10 / 23 / 95$ & 2.0 & .7 & 6.40 & $\mathbf{N}$ \\
\hline USGS 121 & $10 / 24 / 94$ & 2.0 & 2.1 & .50 & \\
\hline
\end{tabular}


Table 48. Comparison of results of replicate pairs of samples from the Idaho National Engineering Labora*ary analyzed for volatile organic compounds

[Analyses by the National Water Quality Laboratory. Samples were analyzed for the whole water, recoverable, constituent. Site identifier: see figures 1-3 for location of sites. Z-value: see section on statistical comparisons for explanation. Remark: no entry, analytical results of replicate pairs are statistically equivalent. Abbreviations: QA, quality-assurance replicate sample; $\mu \mathrm{g} / \mathrm{L}$, microgram per liter. Symbols: <, the result was less than the stated value; ${ }^{*}$, the QA sample was collected within 24 hours of the routine water-quality sample, rather than sequentially]

\begin{tabular}{|c|c|c|c|c|c|}
\hline Site identifier & Date sampled & $\begin{array}{c}\text { Carbon tetrachloride } \\
\qquad(\mu \mathrm{g} / \mathrm{L})\end{array}$ & $\begin{array}{c}\text { Carbon tetrachloride, QA } \\
(\mu \mathrm{g} / \mathrm{L})\end{array}$ & $\mathrm{Z}$-value & Rem?rk \\
\hline USGS 87 & $1 / 11 / 95$ & 1.9 & $* 1.9$ & 0.00 & \\
\hline USGS 120 & $10 / 23 / 95$ & .7 & .7 & .00 & \\
\hline Site identifier & Date sampled & $\begin{array}{c}\text { 1,1,1-Trichloroethane } \\
(\mu \mathrm{g} / \mathrm{L})\end{array}$ & $\begin{array}{c}\text { 1,1,1-Trichloroethane, QA } \\
(\mu \mathrm{g} / \mathrm{L})\end{array}$ & Z-value & Rem $\leadsto r k$ \\
\hline USGS 87 & $1 / 11 / 95$ & .2 & $* .2$ & .00 & \\
\hline USGS 120 & $10 / 23 / 95$ & $<.2$ & $<.2$ & 0 & \\
\hline Site identifier & Date sampled & $\begin{array}{l}\text { Trichloroethene } \\
(\mu \mathrm{g} / \mathrm{L})\end{array}$ & $\begin{array}{l}\text { Trichloroethene, QA } \\
(\mu \mathrm{g} / \mathrm{L})\end{array}$ & Z-value & Remark \\
\hline USGS 87 & $1 / 11 / 95$ & .4 & $* .4$ & .00 & \\
\hline USGS 120 & $10 / 23 / 95$ & $<.2$ & $<.2$ & 0 & \\
\hline
\end{tabular}


Table 49. Results of source-solution blanks, a trip blank, and equipment blanks from the Idaho National Engineering Laboratory analyzed for sodium, sulfate, chloride, fluoride, and chromium

[Analyses by the National Water Quality Laboratory. Site identifier: see Quality Assurance/Quality Control Data, Blank Samples section for explanation. Abbreviations: $\mathrm{mg} / \mathrm{L}$, milligram per liter; $\mu \mathrm{g} / \mathrm{L}$, microgram per liter; $\mathrm{DW}$, deionized water; IBW, inorganjc blank water; VBW, volatile organic compound blank water; na, no analysis. Symbols: <, the result was less than the stated value; ", the sample was analyzed for the whole water, recoverable constituent, rather than dissolved constituent]

\begin{tabular}{|c|c|c|c|c|c|c|c|}
\hline Site identifier & $\begin{array}{c}\text { Date } \\
\text { prepared }\end{array}$ & $\begin{array}{c}\text { Dissolved } \\
\text { sodium } \\
(\mathrm{mg} / \mathrm{L})\end{array}$ & $\begin{array}{c}\text { Dissolved } \\
\text { sulfate } \\
\text { (mg/L) }\end{array}$ & $\begin{array}{c}\text { Dissolved } \\
\text { chloride } \\
\text { (mg/L) }\end{array}$ & $\begin{array}{c}\text { Dissolved } \\
\text { fluoride } \\
\text { (mg/L) }\end{array}$ & $\begin{array}{c}\text { Dissolved } \\
\text { chromium } \\
(\mu \mathrm{g} / \mathrm{L})\end{array}$ & $\begin{array}{c}\text { Hexavalent } \\
\text { chromium } \\
(\mu \mathrm{g} / \mathrm{L})\end{array}$ \\
\hline \multicolumn{8}{|c|}{ Source-solution blanks } \\
\hline QA-2 (DW) & $7 / 1.5 / 94$ & na & na & $<0.1$ & na & $<1$ & $<1$ \\
\hline QA-317 (DW) & $1 / 9 / 95$ & $<0.1$ & na & $<.1$ & na & $<1$ & 3 \\
\hline \multicolumn{8}{|c|}{ Trip blank } \\
\hline QA-318 (DW) & $2 / 1 / 95$ & $<.1$ & na & $<.1$ & na & $<5$ & $<1$ \\
\hline \multicolumn{8}{|c|}{ Equipment blanks } \\
\hline QA-3 (DW) & $7 / 15 / 94$ & na & na & $<.1$ & na & $<1$ & $<1$ \\
\hline QA-5 (IBW) & $7 / 28 / 94$ & $<.1$ & na & $<.1$ & na & $<1$ & $<1$ \\
\hline QAS-39 (IBW, VBW) & $11 / 10 / 94$ & $\#<.1$ & $<.1$ & $<.1$ & $<0.1$ & na & na \\
\hline QA-8 (IBW) & $7 / 17 / 95$ & na & $<.1$ & $<.1$ & na & $<5$ & 1 \\
\hline
\end{tabular}




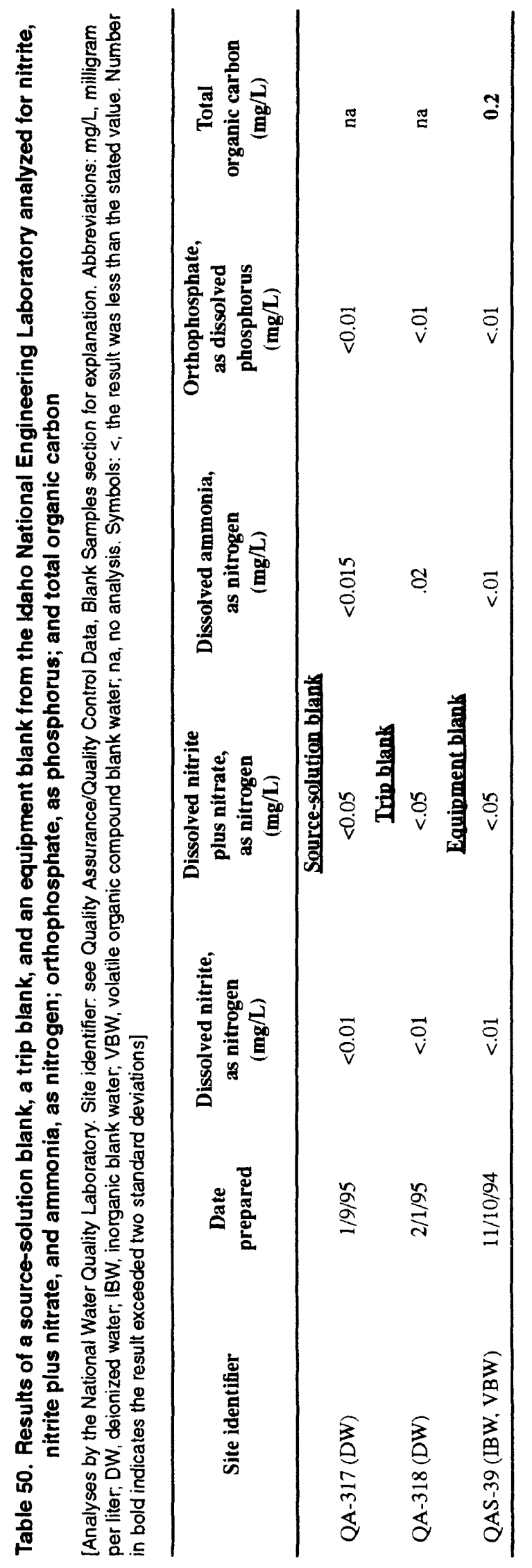


Table 51. Results of source-solution blanks and equipment blanks from the Idaho National Engineering Laboratory analyzed for gamma radiation, strontium-90, and tritium

[Analyses by the Radiological and Environmental Sciences Laboratory (RESL) and the National Water Quality Laboratory (NWQL). Samples for the RESL were unfiltered and regarded as whole water, recoverable (WWR). Site identifier: see Quality Assurance/Quality Control Data, Blank Samples section for explanation. Abbreviations: $\mathrm{pCi} / \mathrm{L}$, picocurie per liter; DW, deionized water; IBW, inorganic blank water; VBW, volatile organic compound blank water; na, no analysis. Symbol \#\#, the analysis was performed by the NWQL for WWR tritium. Number in bold indicates the result exceeded two standard deviations]

\begin{tabular}{|c|c|c|c|c|}
\hline Site identifier & Date prepared & $\begin{array}{c}\text { Gamma radiation } \\
(\mathrm{pCi} / \mathrm{L})\end{array}$ & $\begin{array}{l}\text { Strontium-90 } \\
(\mathrm{pCi} / \mathrm{L})\end{array}$ & $\begin{array}{l}\text { Tritium } \\
(\mathrm{pCi} / \mathrm{L})\end{array}$ \\
\hline \multicolumn{5}{|c|}{ Source-solution blank } \\
\hline QA-2 (DW) & $7 / 1.5 / 94$ & $40 \pm 30$ & $-0.5 \pm 1.6$ & $-60 \pm 170$ \\
\hline QA-3 (DW) & $2 / 8 / 95$ & $-30 \pm 30$ & $1.4 \pm 0.7$ & $-60 \pm 160$ \\
\hline \multicolumn{5}{|c|}{ Equipment blank } \\
\hline QA-3 (DW) & $7 / 15 / 94$ & $14 \pm 21$ & $-.1 \pm 1.6$ & $30 \pm 170$ \\
\hline QA-5 (IBW) & $7 / 28 / 94$ & $-12 \pm 24$ & $-1.8 \pm 1.6$ & $-70 \pm 160$ \\
\hline QAS-39 (IBW) & $11 / 10 / 94$ & na & na & $\# 48 \pm 25.6$ \\
\hline QA-8 (IBW, VBW) & $7 / 17 / 95$ & na & $.9 \pm 0.7$ & $-20 \pm 170$ \\
\hline
\end{tabular}




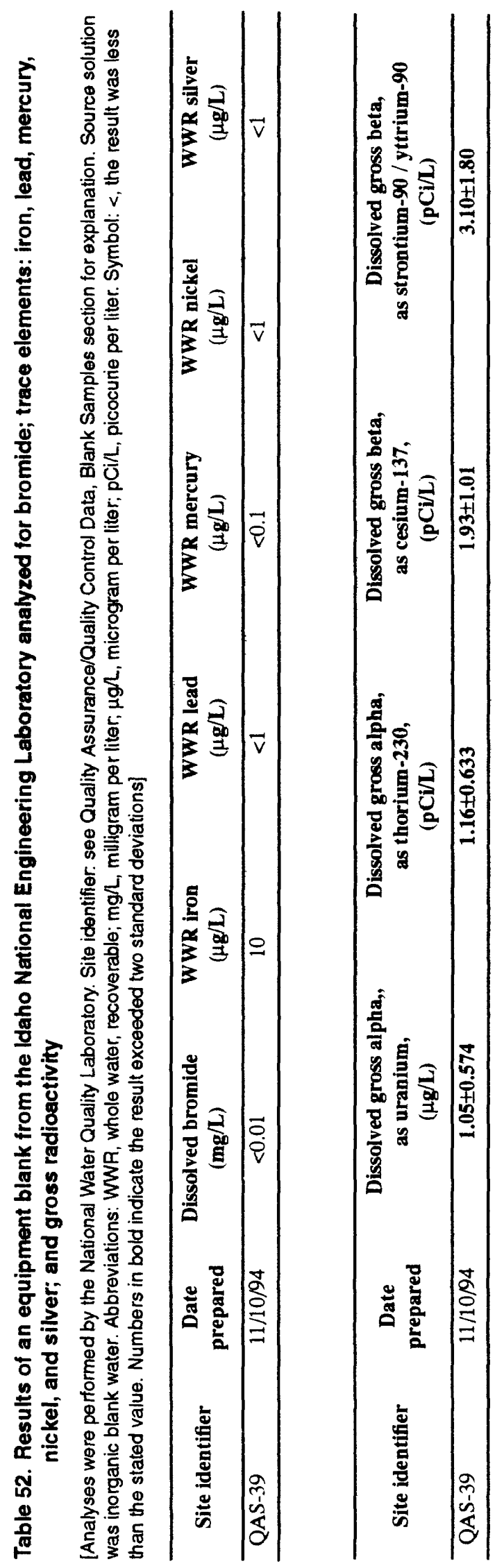


Table 53. Upper-tail areas for a normal curve

[The statistical table was compiled by J.W. Stegeman (Ott, 1993, p. A-3). The level of significance (or p-value) is the area and must be multiplied by two for two-tailed tests. Number in bold is the level of significance for a one-tailed test when $z$ equals 1.96 ]

\begin{tabular}{|c|c|c|c|c|c|c|c|c|c|c|}
\hline z & .00 & .01 & .02 & .03 & .04 & .05 & .06 & .07 & .08 & .09 \\
\hline 0.00 & .5000 & .4960 & .4920 & .4880 & .4840 & .4801 & .4761 & .4721 & .4681 & .4641 \\
\hline 0.10 & .4602 & .4562 & .4522 & .4483 & .4443 & .4404 & .4364 & .4325 & .4286 & .4247 \\
\hline 0.20 & .4207 & .4168 & .4129. & .4090 & .4052 & .4013 & .3974 & .3936 & .3897 & .3859 \\
\hline 0.30 & .3821 & .3783 & .3745 & .3707 & .3669 & .3632 & .3594 & .3557 & .3520 & .3483 \\
\hline 0.40 & .3446 & .3409 & .3372 & .3336 & .3300 & .3264 & .3228 & .3192 & .3156 & .3121 \\
\hline 0.50 & .3085 & .3050 & .3015 & .2981 & .2946 & .2912 & .2877 & .2843 & .2810 & .2776 \\
\hline 0.60 & .2743 & .2709 & .2676 & .2643 & .2611 & .2578 & .2546 & .2514 & .2483 & .2451 \\
\hline 0.70 & .2420 & .2389 & .2258 & .2327 & .2296 & .2266 & .2236 & .2206 & .2177 & .2148 \\
\hline 0.80 & .2119 & .2090 & .2061 & .2033 & .2005 & .1977 & .1949 & .1922 & .1894 & .1867 \\
\hline 0.90 & .1841 & .1814 & .1788 & .1762 & .1736 & .1711 & .1685 & .1660 & .1635 & .1611 \\
\hline 1.00 & .1587 & .1562 & .1539 & .1515 & .1492 & .1469 & .1446 & .1423 & .1401 & .1379 \\
\hline 1.10 & .1357 & .1335 & .1314 & .1292 & .1271 & .1251 & .1230 & .1210 & .1190 & .1170 \\
\hline 1.20 & .1151 & .1131 & .1112 & .1093 & .1075 & .1056 & .1038 & .1020 & .1003 & .0985 \\
\hline 1.30 & .0968 & .0951 & .0934 & .0918 & .0901 & .0885 & .0869 & .0853 & .0838 & .0823 \\
\hline 1.40 & .0808 & .0793 & .0778 & .0764 & .0749 & .0735 & .0721 & .0708 & .0694 & .0681 \\
\hline 1.50 & .0668 & .0655 & .0643 & .0630 & .0618 & .0606 & .0594 & .0582 & .0571 & .0559 \\
\hline 1.60 & .0548 & .0537 & .0526 & .0516 & .0505 & .0495 & .0485 & .0475 & .0465 & .0455 \\
\hline 1.70 & .0446 & .0436 & .0427 & .0418 & .0409 & .0401 & .0392 & .0384 & .0375 & .0367 \\
\hline 1.80 & .0359 & .0351 & .0344 & .0336 & .0329 & .0322 & .0314 & .0307 & .0301 & .0294 \\
\hline 1.90 & .0287 & .0281 & .0274 & .0268 & .0262 & .0256 & .0250 & .0244 & .0239 & .0233 \\
\hline 2.00 & .0228 & .0222 & .0217 & .0212 & .0207 & .0202 & .0197 & .0192 & .0188 & .0183 \\
\hline 2.10 & .0179 & .0174 & .0170 & .0166 & .0162 & .0158 & .0154 & .0150 & .0146 & .0143 \\
\hline 2.20 & .0139 & .0136 & .0132 & .0129 & .0125 & .0122 & .0119 & .0116 & .0113 & .0110 \\
\hline 2.30 & .0107 & .0104 & .0102 & .0099 & .0096 & .0094 & .0091 & .0089 & .0087 & .0084 \\
\hline 2.40 & .0082 & .0080 & .0078 & .0075 & .0073 & .0071 & .0069 & .0068 & .0066 & .0064 \\
\hline 2.50 & .0062 & .0060 & .0059 & .0057 & .0055 & .0054 & .0052 & .0051 & .0049 & .0048 \\
\hline 2.60 & .0047 & .0045 & .0044 & .0043 & .0041 & .0040 & .0039 & .0038 & .0037 & .0036 \\
\hline 2.70 & .0035 & .0034 & .0033 & .0032 & .0031 & .0030 & .0029 & .0028 & .0027 & .0026 \\
\hline 2.80 & .0026 & .0025 & .0024 & .0023 & .0023 & .0022 & .0021 & .0021 & .0020 & .0019 \\
\hline 2.90 & .0019 & .0018 & .0018 & .0017 & .0016 & .0016 & .0015 & .0015 & .0014 & .0014 \\
\hline 3.00 & .0013 & .0013 & .0013 & .0012 & .0012 & .0011 & .0011 & .0011 & .0010 & .0010 \\
\hline & & \multicolumn{2}{|c|}{$z$} & & \multicolumn{2}{|c|}{ Area } & & & & \\
\hline & & \multicolumn{2}{|c|}{3.500} & & \multicolumn{2}{|c|}{.00023263} & & & & \\
\hline & & \multicolumn{2}{|c|}{4.000} & & \multicolumn{2}{|c|}{.00003167} & & & & \\
\hline & & \multicolumn{2}{|c|}{4.500} & & \multicolumn{2}{|c|}{.00000340} & & & & \\
\hline & & \multicolumn{2}{|c|}{5.000} & & \multicolumn{2}{|c|}{.00000029} & & & & \\
\hline
\end{tabular}


Table 54. Site identifiers and sampling dates for replicate pairs of samples from the Idaho National Engineering Laboratory analyzed for volatile organic compounds

[Site identifier: see figures 1-3 for location of sites]

\begin{tabular}{cc}
\hline Site identifier & Date sampled \\
\hline ANP'-9 & $10 / 14 / 94$ \\
Hwy 3 & $10 / 12 / 94$ \\
PSTF & $4 / 10 / 95$ \\
Tan Expl. & $4 / 12 / 94$ \\
USGS 7 & $4 / 06 / 95$ \\
USGS 26 & $4 / 11 / 95$ \\
USGS 87 & $1 / 11 / 95$ \\
USGS 119 & $10 / 25 / 95$ \\
USGS 120 & $10 / 23 / 95$ \\
USGS 121 & $10 / 24 / 94$ \\
\hline
\end{tabular}


Table 55. Volatile organic compounds with Chemical Abstracts Service (CAS) Registry numbers, and minimum reporting levels

[The minimum reporting levels are 0.2 micrograms per liter except where noted (Rose and Schroeder, 1995; Timme, 1994,1995)]

\begin{tabular}{|c|c|c|c|}
\hline Compound & $\begin{array}{c}\text { CAS Registry } \\
\text { number }\end{array}$ & Compound & $\begin{array}{c}\text { CAS Registry } \\
\text { number }\end{array}$ \\
\hline Benzene & $71-43-2$ & 1,3-Dichloropropane & $142-28-9$ \\
\hline Bromobenzene & $108-86-1$ & 2,2-Dichloropropane & $590-20-7$ \\
\hline Bromochloromethane & $74-97-5$ & 1,1-Dichloropropene & $563-58-6$ \\
\hline Bromodichloromethane & $75-27-4$ & cis-1,3-Dichloropropene & $10061-01-5$ \\
\hline Bromoform & $75-25-2$ & trans-1,3-Dichloropropene & $10061-02-6$ \\
\hline Bromomethane & $74-83-9$ & Ethylbenzene & $100-41-4$ \\
\hline$n$-Butylbenzene & $104-51-8$ & Hexachlorobutadiene & $87-68-3$ \\
\hline sec-Butylbenzene & $135-98-8$ & Isopropylbenzene & $98-82-8$ \\
\hline tert-Butylbenzene & $98-06-6$ & $p$-Isopropyltoluene & $99-87-6$ \\
\hline Carbon tetrachloride & $56-23-5$ & Methylene chloride & $75-09-2$ \\
\hline Chlorobenzene & $108-90-7$ & Methyl tert-butylether & $1634-04-4$ \\
\hline Chloroethane & $75-00-3$ & Naphthalene & $91-20-3$ \\
\hline 2-Chloroethyl vinyl ether ${ }^{1}$ & $110-75-8$ & n-Propylbenzene & $103-65-1$ \\
\hline Chloroform & $67-66-3$ & Styrene & $100-42-5$ \\
\hline Chloromethane & $74-87-3$ & 1,1,1,2-Tetrachloroethane & $630-20-6$ \\
\hline 2-Chlorotoluene & $95-49-8$ & 1,1,2,2-Tetrachloroethane & $79-34-5$ \\
\hline 4-Chlorotoluene & $106-43-4$ & Tetrachloroethene & $127-18-4$ \\
\hline Dibromochloromethane & $124-48-1$ & Toluene & $108-88-3$ \\
\hline 1,2-Dibromo-3-chloropropane ${ }^{1}$ & $96-12-8$ & 1,2,3-Trichlorobenzene & $87-61-6$ \\
\hline 1,2-Dibromoethane & $106-93-4$ & 1,2,4-Trichlorobenzene & $120-82-1$ \\
\hline Dibromomethane & $74-95-3$ & 1,1,1-Trichloroethane & $71-55-6$ \\
\hline 1,2-Dichlorobenzene & $95-50-1$ & 1,1,2-Trichloroethane & $79-00-5$ \\
\hline 1,3-Dichlorobenzene & $541-73-1$ & Trichloroethene & $79-01-6$ \\
\hline 1,4-Dichlorobenzene & $106-46-7$ & Trichlorofluoromethane & $75-69-4$ \\
\hline Dichlorodifluoromethane & $75-71-8$ & 1,2,3-Trichloropropane & $96-18-4$ \\
\hline 1,1-Dichloroethane & $75-34-3$ & 1,1,2-Trichloro 1,2,2-trifluoromethane & $76-13-1$ \\
\hline 1,2-Dichloroethane & $107-06-2$ & 1,2,4-Trimethylbenzene & $95-63-6$ \\
\hline 1,1-Dichloroethene & $75-35-4$ & 1,3,5-Trimethylbenzene & $108-67-8$ \\
\hline cis-1,2-Dichloroethene & $156-59-4$ & Vinyl chloride & $75-01-4$ \\
\hline trans-1,2-Dichloroethene & $156-60-5$ & Xylenes ( $m e t a-$ ) & $108-38-3$ \\
\hline \multirow[t]{2}{*}{ 1,2-Dichloropropane } & $78-87-5$ & (para-) & $106-42-3$ \\
\hline & & (ortho-) & $95-47-6$ \\
\hline
\end{tabular}

${ }^{1}$ The reporting level is 1 microgram per liter. 